Portland State University

PDXScholar

8-10-1977

\title{
A Direct and Behavioral Travel Demand Model for Prediction of Campground Use by Urban Recreationists
}

Andre Kimboko

Portland State University

Follow this and additional works at: https://pdxscholar.library.pdx.edu/open_access_etds

Part of the Urban Studies Commons

Let us know how access to this document benefits you.

Recommended Citation

Kimboko, Andre, "A Direct and Behavioral Travel Demand Model for Prediction of Campground Use by Urban Recreationists" (1977). Dissertations and Theses. Paper 455.

https://doi.org/10.15760/etd.455

This Dissertation is brought to you for free and open access. It has been accepted for inclusion in Dissertations and Theses by an authorized administrator of PDXScholar. Please contact us if we can make this document more accessible: pdxscholar@pdx.edu. 


\title{
A DIRECT AND BEHAVIORAL TRAVEL DEMAND MODEL FOR PREDICTION OF CAMPGROUND USE \\ BY URBAN RECREATIONISTS
}

\author{
by
}

ANDRE KIMBOKO

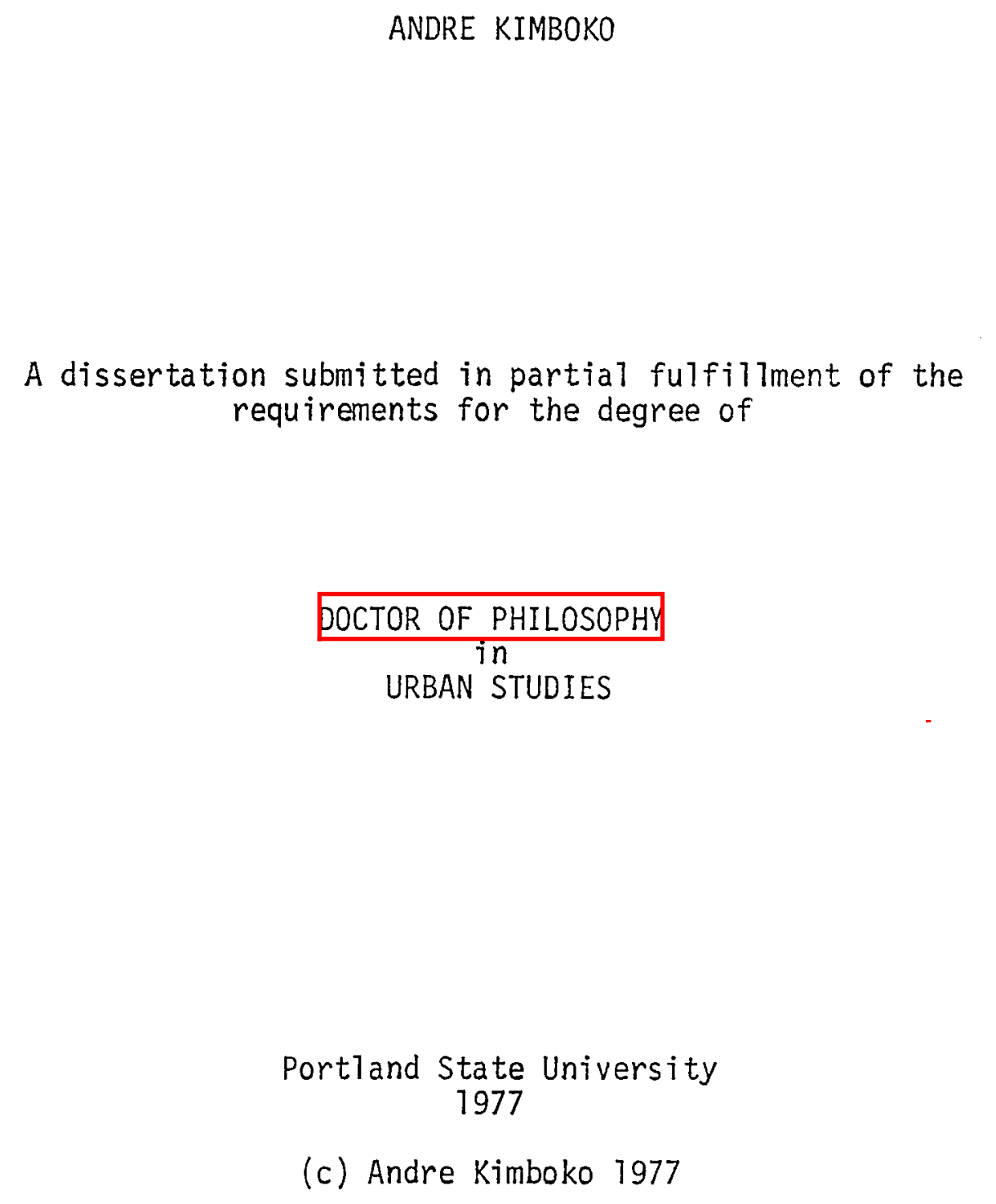


TO THE OFFICE OF GRADUATE STUDIES AND RESEARCH:

The members of the Committee approve the dissertation of Andre' Kimboko presented August 10, 1977.

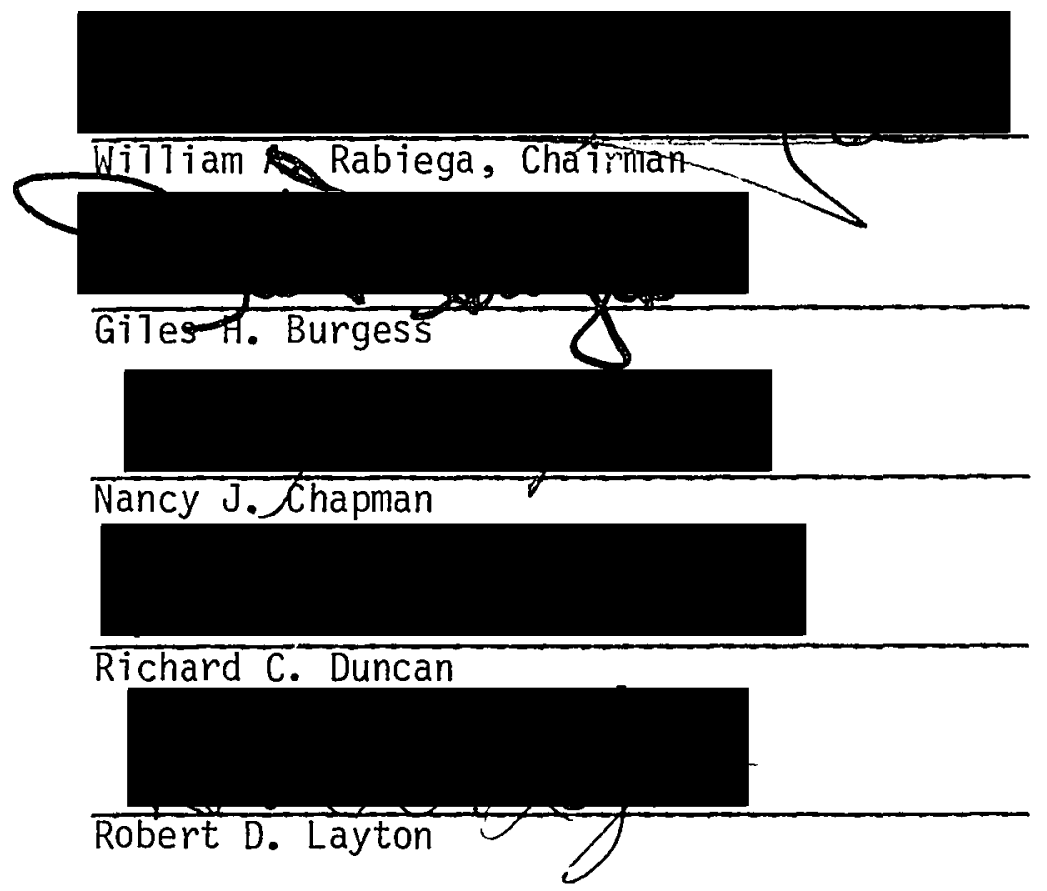

APPROVED:

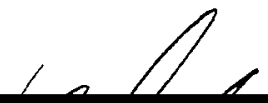

Nohad A. Toulan, Dean, School of Urban Affairs

Stanley E. Rauch, Dean of Graduate Studies and Research 
AN ABSTRACT OF THE DISSERTATION OF Andre' Kimboko for the Doctor of Philosophy in Urban Studies presented August 10, 1977.

Title: A Direct and Behavioral Travel Demand Model for Prediction of Campground Use by Urbar. Recreationists.

APPROVED BY MEMBERS OF THE THESIS COMMITTEE:

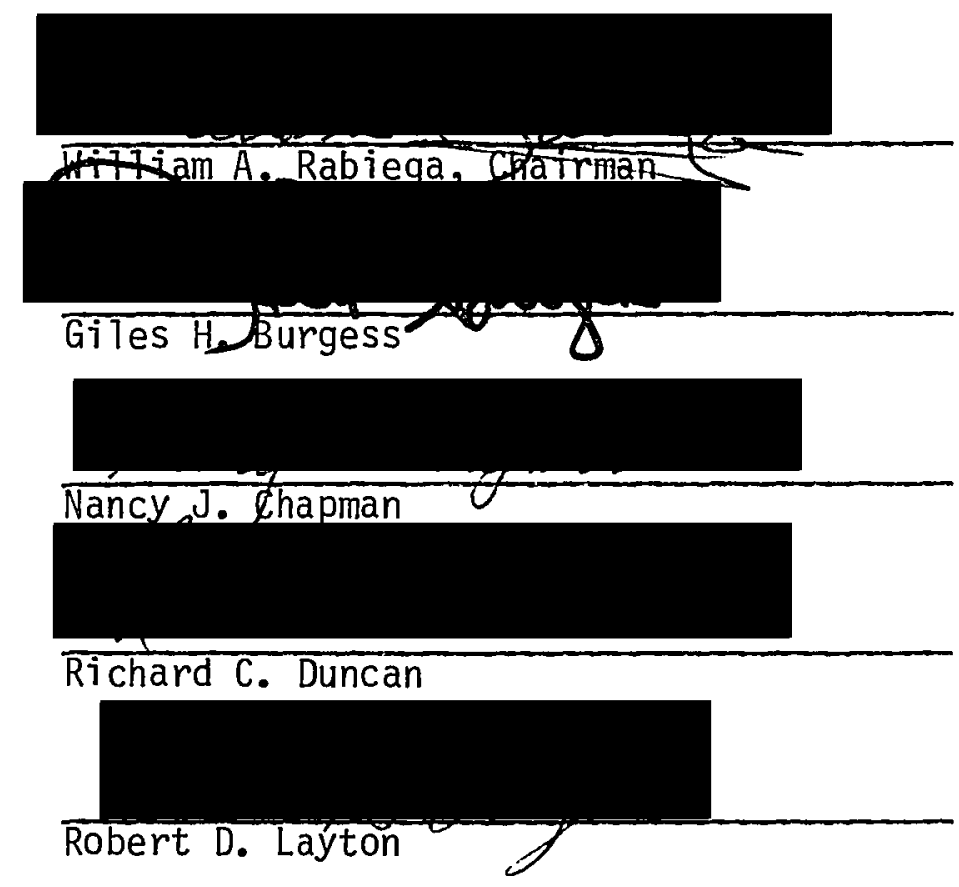

The object of this research is to develop a travel demand model. The model predicts outdoor recreational travel of urban recreationists for camping. The development of this model is structured by a set of methodological criteria. These criteria relate to destination choice behavior in the context of recreation travel, and analytical structures of travel demand, in addition to the criterion of model performance. The thrust of this research is to define and evaluate a destination choice function with respect to recreational travel. This function is introduced into the proposed recreational travel demand model 
as a user preference information, representing the attractiveness index of a recreational site. Of several factors that influence a destination choice, only two were considered: attributes of a site, and mix of activities provided at a site, in addition to camping.

The analytical structure of this model is direct and its functional form is:

$$
T_{i j}=\alpha_{1} p_{i} \tilde{q}_{2}^{\prime} \alpha_{j} \alpha_{3} e^{\alpha_{4}\left(a_{i j}+k t_{i j}\right)}
$$

where:

$\begin{aligned} \alpha_{1-4} & =\text { Model parameters, empirically determined. } \\ e & =\text { Base of natural logarithm. } \\ T_{i j} & =\text { Trip interchanges between points } i \text { and } j .\end{aligned}$

$P_{i}$ is the urban population and is derived from Census information. Travel time, $t_{i j}$, is the time of traveling from one's residence to the site. $a_{i j}$ is a travel cost, the actual cost of operating a vehicle; $k$ is the rate of substitution between $t_{i j}$, and $a_{i j}$. The $t_{i j}$ values were compiled from a highway map showing distances and travel times; the distances were used to calculate the values of $a_{i j}$, as the cost per miles traveled.

User preferences, with respect to thie factors noted are scaled through two psychometric techniques: one establishes score values of preferred alternative mix of recreational activities, using paired comparison, the other provides preference score values for sites' attributes, using information integration theory. These two sets of values are weighted according to the importance that the respondents placed on mixes of activities and attributes of a site. These weighted 
subjective values constitute a proxy for the site's attractiveness, $A_{j}$, the destination function.

The mixes of activities, shown to be associated with camping, are formed using four recreational activities: picnicking, hiking, fishing, and boating. These four activities are arranged in 15 possible mixes resulting in 105 pairs. These pairs are compared two at a time by the respondents. The attributes are those objective attributes shown to influence the selection of a campsite: crowdedness, wilderness and remoteness. These three attributes describe 27 possible sites, a $3^{3}$ factorial design. A value between $0 \%$ and $100 \%$ was given to each one of them by the respondents.

The respondents constitute a convenient sample, drawn from an urban area population.

The calibrated model, with $R^{2}$ of 0.83 , was used to test certain assumptions about travel cost, $a_{i j}$ and the two components of $A_{j}$. The results of these analyses show that the demand for outdoor recreational travel for the purpose of camping, $T_{i j}$, is more sensitive to the changes due to mixes of activities than those due to site's attributes. The effects of attractiveness of a site, $A_{j}$, on the travel demand, $T_{i j}$, are greater than those induced by the travel cost changes, $a_{i j}$. However, the $a_{i j}$ affects the distribution patterns of the travel demand, $T_{i j}$. Changes in the travel cost might not drastically affect camping activity as a whole if changes affecting the components of $A_{j}$, especially the mixes of activities offered at a site are introduced at the same time in the nearby campgrounds within 100 miles of the urban area. 
ACKNOWLEDGMENTS

I gratefully acknowledge the help of Northwest Education Laboratory, Port of Portland and Multnomah County Department of Human Services personnel for their voluntary participation in the filling in of the questionnaire reiated to the evaluation of the campground attractiveness function, a critical component of this study. I would also like to thank the supervisors of the Planning Section and Parks and Recreation Branch of the Oregon Department of Transportation for making available to me transportation and parks information.

A note of thanks is owed to Dr. W. Rabiega, Chairman of the PhD dissertation committee, for his patience, assistance, advocacy attitude and guidance.

Finally, I am indebted to my spouse, while working on her own PhD dissertation, had time to share with me the thrill and vicissitude of a dissertation writing, a most trying period. 
TABLE OF CONTENTS

PAGE

ACKNOWLEDGMENTS ...................... i i

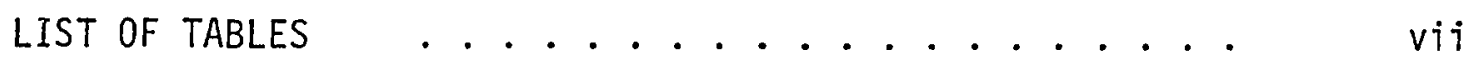

LIST OF FIGURES ................... ix

LIST OF APPENDICES ................... . . .

CHAPTER

I INTRODUCTION .................. 1

BACKGROUND ................ 1

METHODOLOGICAL CRITERIA - AREA

OF INTEREST . ............. 2

RESEARCH TASKS .......... . . 6

LIMITATIONS OF THE RESEARCH . . . . 7

II OUTDOOR RECREATION TRAVEL DEMAND ....... 9

INTRODUCTION ................. 9

TRAVEL DEMAND FUNCTION:DEFINITION . . . 10

TRAVEL DEMAND BEHAVIOR . . . . . . 11

TRAVEL DEMAND STRUCTURES . . . . . . 20

OUTDOOR RECREATION TRAVEL DEMAND

MODELS ................ 25

III. PROPOSED EXTRAURBAN RECREATION TRAVEL

DEMAND MODEL .............. 38

CONCEPTUAL STRUCTURE . . . . . . . 38

COMPONENT SPECIFICATIONS ....... 41

SUMMARY ................ 55 
CHAPTER

PAGE

IV DESTINATION CHOICE FUNCTION:METHODS OF

EVALUATION ............. 58

INTRODUCTION .............. 58

COMPARATIVE JUDGMENT TECHNIQUES . . . 59

INFORMATION INTEGRATION THEORY .... . 60

$\checkmark$ DESTINATION CHOICE FUNCTION: SURVEY DATA

AND EVALUATION ............ . . 65

SAMPLE ................ . . . 65

REPRESENTATIVENESS OF THE SAMPLE . . . . 66

SURVEY FORMS . . . . . . . . . . . 66

ACTIVITY PAIRS ............ 67

SITE ATTRIBUTE INTEGRATION . . . . . . 71

MIX OF ACTIVITY AND SITE ATTRIBUTE WEIGHTS ............ . 80

CALCULATED $A_{j}$ SCORES FOR ACTUAL

VI MODEL CALIBRATION, VALIDATION, AND

EXTENSION .............. . . . 84

INTRODUCTION ............. 84

PARAMETER ESTIMATION RESULTS . . . . . 85

MODEL VALIDATION . . . . . . . . 86

STATEWIDE EXTENSION . . . . . . . . 88

SENSITIVITY AND POLICY IMPLICATIONS . . 92 
VII CONCLUSIONS ...............

MODEL RELATION TO THE METHODOLOGICAL CRITERIA . . . . . ... .

MODEL LIMITATIONS . . . . . . . . .

RECOMMENDATIONS . . . . . . . . .

REFERENCES CITED ...................

168

APPENDICES ....................

115 


\section{LIST OF TABLES}

TABLE

PAGE

I METHODOLOGICAL DEFICIENCIES ........

I I RANKED RECREATION MIX OF ACTIVITY SCALE VALUES, MAV ..................

III MEAN SUBJECTIVE SCORE VALUES FROM SITE'S ATTRIBUTE INTEGRATION RESPONSESRAW DATA . . . . . . . . . . . . .

IV THREE-WAY FACTORIAL DESIGN:ANALYSIS OF VARIANCE STATISTICS ...........

V SCORE VALUES INTEGRATED ACROSS THE SITE ATTRIBUTES .................

VI DERIVATION OF $k$ AND $C$ WEIGHTS FOR THE DESTINATION CHOICE FUNCTION . . . . . .

VII INDEXES OF SITE ATTRACTIVENESS $-A_{j} \cdot \cdots \cdot \cdot \cdot$

VIII PORTLAND AKEA (1975) MODEL:PARAMETER ESTIMATES AND RECREATIONAL (CAMPING)

TRAVEL PATTERNS

IX COMPARISON OF THE ACTUAL AND MODEL ESTIMATED RECREATIONAL TRAVEL PATTERNS FOR THE PORTLAND AREA (1973):MODEL VALIDATION . . . . . . . . . . . . .

$X$ STATEWIDE EXTENSION OF $A_{j}:$ MODEL PARAMETERS

AND TRAVEL PATTERNS BOTH ACTUAL AND

MODEL ESTIMATED . . . . . . . . . . . .

XI MODEL APPLICATIONS :MODEL COMPONENT ALTERNATIVES (ASSUMPTIONS) . . . . . .

XII OREGON STATE CAMPGROUND ATTENDANCE....$\cdot$

XIII LENGTH OF STAY AT A CAMPSITE . . . . . . .

XIV SUBJECTIVE SCORES (VALUES) FROM SITE'S ATTRIBUTE INTEGRATION RESPONSESRAW DATA 
TABLE

PAGE

XV ASSIGNMENT OF MA AND SA VALUES TO THE

SPECIFIC SITE AS SITE

ATTRACTIVENESS, $A_{j} \cdots \cdot \ldots$ 


\section{LIST OF FIGURES}

FIGURE

1 Map showing urban centers (underscored) of 10,000 or more persons for the statewide model .........

2 Map showing Portland subareas considered in the Portland mode . . . . . . .

3 Map showing Eugene/Springfield and Salem subareas considered in the statewide mode 1.............

4. Map snowing the recreational site (underscored) considered in the Portiand and statewide models .......

5 Urban campers travel demand model comporients ...........

6 Graphs showing parallelism ....... 
LIST OF APPENDICES

APPENDIX

PAGE

A OREGON STATE PARKS:CAMPGROUND USAGE . . . . 115

B THEORETICAL DEVELOPMENT OF THE TRAVEL DEMAND ................ 116

C TRIP DISTRIBUTION MODELS . . . . . . . 119

D TRIP INTERCHANGES $\left(T_{i j}\right)$ FOR PORTLAND, EUGENE/SPRINGFIELD AND SALEM SUBAREAS ................ 124

E ANDERSON'S APPROACH TO INFORMATION INTEGRATION ................. 126

F COMPARISON OF SAMPLE AND SELECTED POPULATION INDICATORS:TEST STATISTICS FOR THE PORTLAND URBANIZED AREA ......

G QUESTIONNAIRE:SITE ATTRIBUTES AND MIXES OF ACTIVITIES ............... 135

H MATRIX P: A P X P MATRIX ......... 165

I ELEMENTS OF MATRIX D - UNIT NORMAL DEVIATES ................. 166

$\checkmark$ ANALYSIS OF VARIANCE TABLE, THREE-WAY FACTORIAL DESIGN:COMPUTATION PROCEDURES RESULTING IN STATISTICS IN THE TABLE IV ............

$K$ ASSIGNMENT OF MA AND SA VALUES TO CAMPGROUNDS AS SITE ATTRACTIVENESS, $A_{j} \ldots \ldots \ldots$ 
CHAPTER I

INTRODUCTION

I. BACKGROUND

The demand by urban dwellers for outdoor extraurban recreational activities has increased in recent decades. ${ }^{1}$ This growth has similarly increased the level of use of public recreational facilities and services, and of transportation systems (see Appendix A).

Outdoor recreation requires extensive investment of naturat as well as capital resources. Capital resources are aiso needed for maintaining the existing transportation system and developing new ones. The mounting demand for both outdoor recreation and transportation services implies investment of considerable public funds. Thus, decision makers and the public are faced with at least two important resource allocation problems regarding outdoor recreation. The two are, first, providing outdoor recreation facilities and services and, second, maintaining and/or developing adequate transportation access to these facilities.

A necessary step in solving each of these problems is the projection of future demands for outdoor recreation and transportation services, and the prediction of how these demands will be affected when new or expanded recreational alternatives are available for the users.

\footnotetext{
${ }^{1}$ Extraurban refers to an area outside the urban boundaries.
} 
Even though the methodologies developed in estimating travel demand constitute a substantial literature, there is not a satisfactory outdoor recreational travel demand model available to assist the public and decision makers in these endeavors (Manheim, 1973). Hence, the effort to solve these problems has been hampered.

\section{METHODOLOGICAL CRITERIA - AREA OF INTEREST}

The purpose of this study is first to review various predictive models used to estimate outdoor recreational travel demands of urban dwellers and then to improve upon such methodology. While research hypotheses in the strict sense are not under investigation, there are methodological criteria that will assist and guide this effort.

Several methodological criteria can be established with respect to the development of a model for estimating travel demand. Those included here deal with spatial interaction modeling efforts concerned with consistency (Manheim, 1973; Wilson, 1974), and user choice behavior as related to destination alternatives (Michaels, 1974; Golob and Dobson, 1974). More specifically, the use of an analytical structure which leads to an internally consistent model, and the inclusion, into the travel demand modeling process, of subjective information regarding the choice among alternative destinations for recreational activity, is considered best.

These aspects are essential to the development of this present model. Thus, this study is concerned with choice behavior as it is related to destination selection in the context of the outdoor recreational travel demand. The model consistency aspect is to ensure the 
selection of a modeling approach which best allows explicit introduction of uniformly treated alternative transportation system factors into the travel demand function. The criteria below constitute a framework within which past models will be evaluated and which will direct the development of this present model. The proposed model must excel on the totality of these criteria to improve on existing ones. The criteria are:

\section{Internal Consistency}

The model must be consistent. The value of each level-of-service variable describing the transportation system should be the same at each stage of the forecasting process (Wilson, 1970, 1973, 1975; Manheim, 1973; Fisk and Brown, 1975; Brand, 1973; Nakkash and Grecco, 1972; Haney et al., 1972)! In this study, the level-of-service variables considered are travel time and vehicle operating costs.

\section{User Preference Information}

The model should be defined with respect to preferred destination choice attributes, preferred types of outdoor recreation activities, and preferred alternatives among recreational sites. These preferences are best derived from user rather than secondary judgments (Michaels, 1974; Hartgen arid Wachs, 1974; Golob and Dobson, 1974).

1"Level-of-service. . a qualitative measure that represents the collective factors of speed, travel time, traffic interruptions, freedom to maneuver, safety, driving comfort and convenience, and operating costs provided by a highway facility under a particular volume condition." (Robinson, 1976, p. 373). 
Two additional criteria will be considered: simplicity and performance. The criterion of simplicity will be used to select a structure of the travel demarid function, consistent with the internal consistency criterion. The performance criterion will be looked upon as a measure of the ability of a model to produce accurate travel demand estimates. These criteria are detailed below:

\section{Simplicity}

The model should use a minimum number of independent variables (Nakkash and Grecco, 1972; Brand, 1973; Hartgen and Wachs, 1974). Moreover, a process involving few steps is favored over one involving many, thus, direct estimation procedures are favored over those which rely on iteration or linked submodels to derive estimates for each forecast time period if each process predicts with equal accuracy (Peat et a1., 1973; Hartgen and Wachs, 1974).

\section{Performance}

A model proposed to supplant existing ones must, in addition to conforming to the above criteria, produce more accurate predictions than those previous to it.

The efficacy of the internal consistency, simplicity, and performance criteria is self-evident, however, requiring that user preferences be included in the modeling process requires some further discussion. Michaels' (1974, pp. 53-56) comments on this subject pertain: 


\begin{abstract}
- . Observed choice behavior is the product of the evaluation of the alternatives in terms of subjective needs, attitudes and preferences. . . This need and preference structure is an inherent characteristic of human behavior that is not determinate directiy from observed behavior. - . The nature of this structure may be inferred by direct measurement of attitudes and preferences toward qualitative or quantitative dimensions of the physical or social environment.
\end{abstract}

- . it becomes essential to enter the domain of direct measurement of human attitudes, preferences, and choices. t.t means that models must be constructed that are based on these kinds of processes rather than the prosaic methods and expedient measures that have characterized traditional transport planning models. . .

\begin{abstract}
- a model such as trip generation, distribution, or mode choice, validity and reliability are likely to be higher when such a model is constructed on the basis of behavioral measures rather than physical measures, especially when the latter are selected simply because they are convenient or easy to measure. . . . For instance, automobile availability should be a good predictor of mode choice simply because it determines whether travelers have a choice. It describes the trivial case. Clearly, it can and does say nothing about satisfaction with transportation, nor will it predict what people will do if they are given new options, i.e., choice alternatives.
\end{abstract}

Where Michaeis observes decisions may be inferred from attitudes, he perhaps overstates the correspondence of attitude and behavior. There is considerable argument within psychology on this point currentiy (Wicker, 1969). However, assuming that attitude and behavior correspondence remains reasonable for the purpose of investigating urban travel demands, then the following inferences can be made: first, it allows modeling of proposed changes in a transportation/recreation system without having to observe reactions to actual stimuli. Second, it may be impossible to execute experiments which would allow observation of actual behaviors prior to estimating impacts of future changes 
in an uncontrolled naturalistic recreational environment. Thus, models based on attitude/behavior congruence at least deserve close consideration and may be the only practical alternative. Third, as Michaels noted, inclusion of behavioral, i.e., attitudinal measures, is more

likely to produce useful results than past methods in which "objective" measures, such as number of campsites, were introduced in modeling structures with little or no analysis of how they pertained to other variables in a preference ordering of recreational sites.

\section{RESEARCH TASKS}

The above criteria also define the research tasks. The first is to assemble, synthesize and summarize what is known about recreation travel behavior. This establishes what variables are significant to outdoor recreational travel behavior. Then follows a critical analysis of selected models previously used to estimate outdoor recreation travel demand as to how we!? they meet the methodological criteria. This amounts to determining how factors that are important to outdoor recreation travel behavior, including the alternative destination choice, are combined into a consistent and simple mathematical structure which represents an outdoor recreational travel demand model. By this review, strengths and weaknesses of these models will be established. Third, an extraurban outdoor recreation travel demand model is specified within the framework established by the methodological criteria for investigation in this study. This involves: (1) the determination of the model structure to represent the travel demand for outdoor recreation; (2) the specification of the model components; these must include at least a site attractiveness variable, represented by preferences for 
alternative destinations and a variable indicative of ease of movement within the transportation system.

The last task of this study is centered around the calibration of the model using the most recent data possible, and the testing of the model for its predictive ability by using data sets. Methodological and substantive findings will then be summarized. The latter are regarded as a by-product since the thrust of this research is to improve methodology.

The data gathered to calibrate and test this model are of three types: (1) survey data to operationalize the site attractiveness function, i.e., simulated destination alternatives, formed from important factors in selecting a place for camping, as evaluated by potential recreationists; (2) secondary data to derive the travel patterns representing round trips from Portland subareas to selected state parks, including travel times and distances; and (3) population data from the Census of Population. Both 1973 and 1975 travei patterns and times were gathered. The details of these data sources are given in Chapters 3 and 5.

\section{LIMITATIONS OF RESEARCH}

The model is limited topically to one activity and the field test geographically. The specific extraurban recreational behavior investigated here is camping. This is in part due to the practical limitations of a single researcher carrying out a prototype project and in part because camping is one of the most popular recreational activities for urban dwellers and is the most capital intensive of all 
outdoor recreational activities in Oregon in terms of supply (Parks and Recreation Branch, Oregon Department of Transportation). The camping opportunities under study are limited to state parks in Oregon and the travel pattern data employed to estimate the model parameters are from that state. The survey data used to evaluate the destination choice function were derived from urban dwellers of Portland, Oregon. Notwithstanding these substantive limitations, this application can serve as a prototype. If the methodology shows evidence of advance, it can be extended to other urban recreation travel and to any transportation demand modeling process in which site attractiveness is an active variable. 
CHAPTER II

OUTDOOR RECREATION TRAVEL DEMAND

I. INTRODUCTION

Blackburn's (1970, p. 164) statement,

A11 transportation demand models can be decomposed into terms which measure the mutual attractiveness of origins and destinations and terms which measure the efforts of the impedance imposed by the transportation system.

can be mathematically expressed as follows:

$$
T_{i j m n}=f_{i j m n}(A, S, L)
$$

where ${ }^{1}$ :

$$
\begin{aligned}
& T_{i j m n}=\text { Trips from origin } i \text { to destination } j \text { for } \\
& \text { the purpose } m \text { and by mode } n \text {. } \\
& \mathrm{L}=\text { Represents the level-of-service variables } \\
& \text { (iiiipedance); it includes travel time, op- } \\
& \text { erating costs, safety, ... . It is also } \\
& \text { referred to as generalized cost variable. } \\
& S=\text { Represents the socio-economic variables or } \\
& \text { conditions at the origin; it includes popu- } \\
& \text { lation characteristics such as income } \\
& \text { (monetary budget), time availability for } \\
& \text { travel and for taking part in an activity } \\
& \text { (time budget),... } \\
& A=\text { Measures the intensity or attraction of the }
\end{aligned}
$$

${ }^{7}$ This notation is consistent with standard mathematical notations. It is often used to represent a function where exact relations among the variables are unknown. 


$$
\begin{aligned}
f_{i j m n}= & \text { Some travel demand function of the trans- } \\
& \text { portation services from origin } i \text { to des- } \\
& \text { tination } j \text { for the purpose } m \text { and by mode } \\
& n \text { at the level-of-service } L, \text { and given } A \\
& \text { and } S .7
\end{aligned}
$$

Any or all of the $L, A$ and $S$ variables relate to by some functional form. The above mathematical expression is generally referred to as a travel demand function (Ruiter, 1973) and it has been the object of considerable research (Manheirn, 1973; Wi1son, 1970, 1973, 1975; Brand, 1973; Watson, 1974; Demetsky, 1974; Hartgen and Wachs, 1974; Roberts, 1973; Ruiter, 1973).

This chapter reviews the literature related to four aspects of this function: (1) definition of the function; (2) determination of its structures; (3) specification of its components with respect to recreation travel; and (4) analysis of selected demand models previously used to estimate outdoor recreation travel. Emphasis is placed on the last two aspects since they are pertinent to the object of this study.

\section{TRAVEL DEMAND FUNCTION : DEFINITION}

One definition of the travel demand function (see Equation?, page 9 ) is provided by the consumer demand theory developed in the field of micro-economics (Quandt, 1974; Ruiter, 1973). As developed in a number of studies, including Ruiter's, this theory views trave? demand $\left(T_{i j m n}\right)$ as an intermediate economic good (Quandt, 1970; Wilson, 1974). The travel decision making process is defined as a trade-off

I In this study, mode refers to transportation means used to travel from point $i$ to location $j$, e.g., automobile, bus, etc. 
between the benefits derived from participating in activities and the costs incurred by the travelers to reach the place where those activities are located. Travel demand is thus a derived demand since "it is due to the demand for other goods rather than to its own contribution to the consumer's utility" (Ruiter, 1973, p. 179). The incurred costs are represented by the level-of-service (L) variables. The activities (A) are those which are available at the destination and which are defined with respect to the travel purpose. The characteristics of the travelers $(S)$ describe the conditions at the origin. Hence, the travelers choose the travel path which minimizes the costs (L), while selecting among destination alternatives the one which maximizes the benefits, to take part in the activities (A) at a given time and destination. A detailed discussion of these concepts is given in Appendix $B$.

\section{TRAVEL DEMAND BEHAVIOR}

This theoretical definition of the travel demand function must match empirical findings to be a strong basis for an operational moder, particularly one which can be used to evaluate alternative sites and transportation system investment strategies. Results of investigations into the effects of a number of independent variables on travel demand are detailed below, with this consideration.

\section{Economic Effects}

Effects of economic factors on the level of participation in outdoor recreation have been investigated by several groups. Volk (1965), 
using a multiple regression technique, studied the effects of mobility and median income on recreational area attendance. Clawson and Knetsch (1962) report similar studies on the same factors in addition to leisure time availability. Although these factors showed relationships with participation in outdoor recreation activities, time-distance accounted for most of the variance, as high as 90 percent (Volk, 1965) in certain instances.

For outdoor recreationists, travel time and time spent participating in a given activity are important components of leisure time (Clawson and Knetsch, 1962). This has been termed the time budget and is obviously consistent with the interpretation of travel time as a $\operatorname{cost}(L)$.

In a summary of a national study on outdoor recreation participation, sponsored by the Outdoor Recreation Resources Review Commission (ORRRC), Mueller and Gurin (1962) noted that income, occupation and education are directly related to participation in outdoor recreation. These findings were consistent with those resulting from other national studies by the Midwest Research Institute (MRI) in 1973, ORRRC in 1960/ 61, and a 1974 regional study reported by Berg et a1., (1974) and sponsored by the Upper Great Lakes Regional Commission (UGLRC) encompassing Michigan, Minnesota and Wisconsin states. The UGLRC, ORRRC and MRI studies included at least ten different outdoor recreation activities each.

While many of these variables are used to distinguish social status as well as economic capabilities, e.g., occupation, and can enter the model as conditions at origin (S), travel time and costs of 
travel constitute an economic constraint on recreation travel. Thus, their consideration as cost variables $(L)$ is consistent with empirical findings. It is also evident from this why study of spatial gradient effects as a surrogate for travel costs has been emphasized.

\section{Spatial Gradient Effects}

One of the most studied factors influencing outdoor recreation demand is the effect of distance on visitation rates (Volk, 1965; Matthias and Grecco, 1968; Clawson and Knetsch, 1962; Robinson and Grecco, 1962; Deacon et a1., 1973). Most of these studies analyze the effect of distance on the demand, and compute per capita visits for one or several outdoor recreation activities from population centers to recreational areas. The results are plotted against distance from population centers to the recreational areas. The resulting curve shows a fall-off of visits with increasing distance.

A similar process is used by Crevo (1963) in a study of weekend recreational travel to parks in Southeastern Connecticut to evaluate the effect of travel time. Actual trips from origin zones to parks are plotted against travel time between origins and the parks. In both of these cases, the resulting spatial gradient curves are exponential in form. Van Doren (1965) employs a time-distance factor in studying patterns of outdoor recreation demand; the relation also shows a spatial gradient. Again, the cost effects of impedance were affirmed.

\section{Place of Residence Effects}

Demographic as well as urbanization effects on outdoor recreation demand have been studied. These are termed place of residence effects, 
a component reflecting conditions at the origin ( $S$ ). Age, race, and place of residence were included in the UGLRC, ORRRC and MRI studies. Urbanization, i.e., residence in urban settings, as it affects demand, was investigated by Hauser (1962). The Hauser study reviews demographic and home location changes as factors affecting outdoor participation. Hauser found that residents of metropolitan areas tend to have a lower participation rate with respect to camping than do people in small cities (p. 48, Table 5). The result supports the ORRRC's (Study Report 19, 1962, p. 32) early findings that:

The rural resident camps more per person than the urban resident in the West ( 1.05 to 0.48 days) and the Northeast ( 0.33 to 0.27 days). Highest participation rates obtain among the rural nonfarm residents of the West. While the rural resident participates more in camping than the United States urbanite ( 0.59 to 0.36 days), this pattern is by no means uniform within each region. The North Central States, notably, deviate from it, partiy because of the low rates for the rural population outside of SMSA's.

The same conclusion is also reached by Thompson (1967) in his study of the flow of the campers in the Province of Ontario, Canada, where he notes that: "the volume of camper traffic generated appears to vary with the size of the city. Large cities generate proportionally fewer campers than smaller cities." He attributed this to: "the fact that large cities have many recreational activities that are not found in smaller cities" (Thompson, 1967, p. 541).

Burch and Wenger (1967) did an empirical study of the social characteristics of participants in three styles of family camping in Lake of the Woods and Three Sisters areas in Oregon. They found slightly different camping participation rates as function of place 
of residence. Cities of 50,000 or more people generate a higher number of camping trips than others, including suburban areas within 15 miles of large cities. Their sample may be too limited for generalizations. About 88.0 percent of their sample were residents of Oregon. Differences in outdoor recreation demand among urbanized area and small city dwellers are not limited to camping participation rates. According to Catton (1969), there is a difference between urbanized area and town campers' attitude toward wildiand recreation. Catton used information derived from a questionnaire of scale items to assess urbanism and wildernism attitudes toward wildland recreation. Responses were cross-classified by place of residence. These responses were obtained from recreationists who have visited the Eagle Cap Wilderness and the Three Sisters Wilderness in Oregon, and Glacier Peak Wilderness in Washington ( $p, 10)$. Catton defined the wildernism attitude as that attitude which "implies a willingness or even a desire to adapt one's habits to the environment, rather than adapting the environment to one's habits" (p. 7). Outdoor recreationists holding urbanist attitude would sometimes impose "urban apparatus and activities upon wildland recreational environments such as forest or mountain campsites and trails" (p. 7). The scale items dealt with features of wilderness-type areas, activities deemed appropriate or inappropriate to wilderness-type areas and benefits that might be obtained from recreation in wilderness-type areas. An average score of "wildernism" was computed for each subject. The subjects were then categorized using their scores and referred to as urbanists, neutralist, weak wildernists, moderate wildernists, or strong wildernists. Catton (1969, p. 11) found that: 
Only 6.3 percent of the city-bred respondents were urbanist or neutralist in their value-orientations, compared with 8.3 percent of those raised in small towns, and 11.4 percent of those who grew up in rural areas. Conversely, of the 409 who said they had been brought up in a city, 67.0 percent were moderate or strong wildernists. Of the 508 who said they had been raiseu iii a sirai i cown, 59.6 percent were moderate or strong wildernists, and of the 405 who grew up in the country, 53.1 percent were moderate or strong wildernists. Seventeen percent of the variance in wildernism scores was thus explained by the trichotomous response to this one simple question on place of origin.

Several points are pertinent to the general model form used in these studies. First, the effects of social and economic status variables seem to be less than those of the cost related variables. Second, these effects vary with local status structures and tastes. The negligible relation of these variables to demand in the Oregon study is notable in this regard. Third, though it is not directly evident, urban travel behavior and wildernist views are supportive of the model in two ways: (1) what appears first to be a discrepancy between behavior and attitude in that residents of large cities hold wildernist attitudes, large city dwellers yet have lower proportional attendance at outdoor recreation sites than small city dwellers who hold more urbanist preferences, reduces to a travel cost effect when one considers that most residents of small cities are closer to outdoor recreational opportunities than residents of large cities; and (2) urban dwellers have a common and distinctive preference for wildernist activities. It follows from this latter point that they should find potential recreational sites attractive according to the wilderness characteristics of the locale. 
Destination Choice Behavior

Effects of the site attributes, or destination characteristics, the remaining variable in the model $(A)$, have also been investigated. The destination characteristics describe the location of the outdoor recreation facilities and services. The choice of a destination for the purpose of taking part in outdoor recreational activities can be considered as being largely determined by the physical attributes of the area and the type of recreational activities offered. It is independent of travel time and costs (Thompson, 1967; Ellis and Van Doren, 1966; and Lime, 1971, 1972).

In the next literature review, the emphasis is placed on destination choice for the purpose of camping with a main concern on finding about how campers select campgrounds on the basis of site attributes.

In a study of campground use in the Superior National Forest of Minnesota during the peak of the 1968 season, Lime (1971) interviewed 248 campers to determine why they selected their campground from among those in the forest (Lime, 1971, p. 10). Campers "were also questioned about trip planning, previous camping experience, knowledge of alternative places, sources of information about campgrounds, and preferences for individual campsites in a campground" (Lime, 1972, p. 202).

He found that most campers selected a campground before they left home, knew where they were going and why ( 80 percent) and many had considered alternative campgrounds ( 30 percent). Among the factors considered in picking a campground were many reflecting wilderness preferences--uncrowdedness, absence of man-made features, solitude and tranquility, remoteness, individual campsites both within sight of the 
Take or stream while being well-screened from neighbors, small size campground (less than 15 campsites), and closeness to other recreation attractions, e.g., fishing, boating, canoeing.

The closeness factor was also found to be important in Thompson (1967) and Marans' (1972) study. Marans' study was based on residents of planned residential communities of the new town type. Nevertheless, he found significant relationships between availability of outdoor recreation facilities for swimming, tennis, boating, hiking and walking with frequent participations in these activities. The findings by Lime (1971), Thompson (1967), and Marans (1972) related to this factor, also validate the ORRRC's (1962) results on outdoor recreational activities associated with camping.

Thus, both the phenomena of physical site attributes and localized additional recreational opportunities are part of destination characteristics (A variables) considered by campers. Further, the high degree of pre-travel site selection evidenced in the Lime (1972) study points to the congruence of preference structure and behavior.

\section{Conclusions}

Numerous studies in different geographic settings have been devoted to outdoor recreation demand behavior. In reviewing this body of literature with respect to camping, the following factors appear important:

1. Time and travel costs can be looked upon as elements of spatial gradient effects on recreational demand. 
2. Place of residence (urbanization) effect can be translated into differences in participation rates and attitudes toward the selection of campground, destination choice.

3. Physical attributes of the recreation areas and the recreational activities offered influence the choice of a campground. Important physical attributes include level of wilderness, number of campsites, closeness to other recreational activities, and natural aspect of the area. The recreational activities usually associated with camping are fishing, boating, hiking, horseback riding, water skiing, picnicking, and swimming.

These factors relate to the three main components of the travel demand function as expressed in the Equation 1: time and trave1 costs constitute the impedance, place of residence effects represent the characteristics at the origin and physical attributes of the recreational areas and recreational activities are the destination characteristics. The development of accurate models pertains to how the relationship ( $f$ ) of these components is stated and variables are operationally defined and measured. A basis for selecting an appropriate form of the recreational travel demand function, consistent with the criteria of consistency and simplicity, is established below. 


\section{TRAVEL DEMAND STRUCTURES}

Several analytical structures are used to model travel demand. They can be grouped into two broad categories: indirect (traditional, conventional, or sequential) and direct (Manheim, 1973). However, other classifications are possible (Ruiter, 1973). The analytical structures are also referred to as approaches to estimating travel demand.

\section{Sequential Structure}

The traditional approach estimates the travel demand in a series of sequential steps; the output from the preceding step forms the input to the next step. This results in a four-step estimating procedure: (1) trip generation or travel choice; (2) trip distribution or destination choice; (3) mode choice; and (4) minimum-path or multipath trip assignment or route choice. The first of these steps determines the number of trips which might originate or terminate within a given area/place; e.g., a park area, for a given purpose, e.g., camping. The second one specifies the destination (or the origin) of these trips. The third step allocates the trips to the various modes of travel. The fourth step assigns the trips to specific routes on the transportation network. Each of these steps or phases may be expressed in a functional form. The trip generation step amounts to estimating the trip ends; e.g., number of trips originating (trip productions) from an area, and the number of trips arriving (trip attractions) at the same area. Usually a regression technique is employed in this process with trip ends, trip productions and attractions, as dependent 
variables, and a set of appropriate factors are used as explanatory variables. Two regression equations are derived; one for the trip productions and another for the trip attractions for each traffic zone in the study area under consideration. ${ }^{1}$ The trip generation analysis phase essentially estimates the trip ends on the traffic zone level regardless of where the produced trips might go or where the attracted trips are from for a given travel purpose. Skills in regression techniques and in the choice of appropriate explanatory variabies are necessary requirements for applying the trip generation step.

In the second step, the produced trips are distributed among different destination zones as attracted trips, given the spatial gradient effects between the origin and destination zones and the trip attractions in the destination zones. For a given destination zone, the trip attractions, as calculated in the first step, should be equal to the trips attracted, as computed in the second phase. An iterative process must be employed in order to balance these two sets of data or to simulate the actual trip attractions because the independent submodels produce varying estimates. There are three types of models that are commonly used for the trip distribution phase. They are gravity, intervening opportunity, and system theory models. Essentials of these models are given in Appendix $C$.

F For the purpose of this study, a traffic analysis zone is defined as a subdivision of the study area (U.S. Department of Transportation, Federal Highway Administration, March 1972). 
The third and fourth steps are those of mode and route choices. The models related to these steps are not discussed here since only the auto mode of trave 1 is considered and campers are assumed to travel by choosing the shortest paths to reach their destinations so as to minimize the impedance imposed by the transportation system (Whitaker and West, 1968; E17is and Van Doren, 1966; Quandt, 1970; Blackburn, 1970; Ruiter, 1973).

\section{Direct Structure}

The direct travel demand structure, on the other hand, combines the steps of the traditional structure in a single process or step to define the travel demand function. In theory, all the steps of the traditional structure can be combined in one step, however, in practice it is convenient to separate the sequence into two groups at the mode choice step. Modes have different characteristics, and may have different route choice requirements. Variation in this division is also possible: share models, trip end and/or post-trip distribution mode choice models, and other (Manheim, 1973).

Advantages and Disadvantages of Sequential and Direct Structures

Manheim (1973) and others have noted at least three problem areas in applying the traditional approach.

First, it implies a four stage decision process (Brand, 1973 and 1974). Potential users of transportation would first decide if they want to travel, then select their exact destination from their origin, then choose between a private auto or public transit, and finally they would select their route. Peers et a1. (1975) maintains that this type 
of decision process is not substantiated by prior research. They are, at best, conveniences for computation purposes (Brand, 1974, p. 189). Rather, a decision where all factors are considered simultaneously is implied. Further, the sequence is in contradiction to the general economic reasoning behind the travel demand model.

As noted earlier, travel is a demand derived from seeking goods, services, etc., at a point other than one's current location. A consumer of transportation services decides first where he wishes to go according to this reasoning, not second, as is the case in the trip distribution phase of the indirect model.

Second, given that a closed system model is assumed, the total trips generated should equal the total terminated. This is:

$$
\begin{aligned}
& T_{j}=\sum_{i=1}^{\sum_{i j}} \\
& T_{i}=\sum_{j=1}^{m} \\
& T_{t}=\sum_{i=1}^{n}=\frac{T_{i}}{j=1}
\end{aligned}
$$

for:

$$
\begin{aligned}
T_{t} & =\text { Total trips in the region. } \\
T_{i} & =\text { Trips originating from } i . \\
T_{j} & =\text { Trips destined to } j . \\
T_{i j} & =\text { Trips going from } i \text { to } j .
\end{aligned}
$$




$$
\begin{aligned}
& n=\text { Number of origins. } \\
& m=\text { Number of destinations. }
\end{aligned}
$$

In fact, this is not always the case within steps of the traditional approach as the estimates of productions and attractions from step one are the inputs to step two, and errors made in the first projections will be compounded. Additionally, there are trip equivalence problems within steps as detailed earlier ( $p .21)$.

Third, the first step, trip generation, in the traditional modeling process usually involves no independent variables indicative of the level-of-service offered in the transportation system. The second step, trip distribution, may involve measures of distance or travel time. Modal choice may involve a series of travel time and comfort measures, and trip assignment still other sets of level-of-service variables. As Manheim (1973, p. 24) observes, if level-of-service variables are important in the process, consistent effects should pertain throughout the modeling process. Yet, as the same dependent variables are related to differing independent ones at the various steps, different structures and parameters with regard to them are inevitable.

The direct structure, which combines steps one, two, and sometimes three, would obviousiy be more acceptable for travel demand modeling. It assumes a simultaneous evaluation process. It cannot produce errors which compound from step to step because it has only one step. Likewise, variables cannot be differentially applied at different steps because there is only one step, a single structure, and a single set of parameters. It is clear, then, that the direct 
method is stronger based on the methodological criteria of simplicity and consistency.

Next comes a review of the models in representative recreational demand studies on all four criteria, to establish a context in which to compare the model suggested in this research.

\section{OUTDOOR RECREATION TRAVEL DEMAND MODELS}

Five such models are reviewed below that illustrate both general modeling approaches. As previously stated, the traditional approach involves estimating the travel demand through steps, mainly the trip generation and distribution steps. The direct approach combines these two phases into a single step. Hence, the demand models reviewed here are grouped into two categories, those based on the traditional approach and ones based on the direct approach. In all the models to be reviewed the emphasis will be placed on model consistency and specification of destination choice function with respect to recreational travel.

\section{Sequential Models}

Ungar Study. A typical traditional approach for estimating travel demand for outdoor recreation, without considering transportation system attributes, is illustrated by the work of Ungar (1967). The purpose of his study was to estimate the traffic attraction of rural Indiana reservoir recreational areas. The trip generation phase estimated the trip productions and attractions, and the produced and attracted trips were distributed using gravity and variant gravity models. The trip production equation was evaluated by relating the recreational participation rates to socio-economic variables. The trip attraction 
submodel was represented by a linear regression equation. This equation related the number of observed trips to a recreational area to a set of variables "that described a collection of such areas in terms of their known characteristics" (Ungar, 1967, p. 15). Ungar started with a set of 48 variables. Through an elimination process, this set was reduced to the variables shown in the equation below (ibid., p. 16):

REGRESSION EQUATIONS FOR ATTRACTIVENESS OF PARKS

\begin{tabular}{|c|c|c|c|}
\hline $\begin{array}{l}\text { Eq. } \\
\text { No. }\end{array}$ & Equation ${ }^{\mathrm{a}}$ & $\begin{array}{l}\text { Mult. } \\
\text { Corr. } \\
\text { Factor }\end{array}$ & $\begin{array}{c}\text { Std. } \\
\text { Error } \\
\text { (Trips) }\end{array}$ \\
\hline (6) & $\begin{aligned} Y= & -903.6+6.1 T-5.8 C+3.6 L+2.2 D-646.3 B \\
& -2.6 G+726.5 F-430.0 R+217.7 E+0.01 P\end{aligned}$ & 0.926 & 309 \\
\hline (7) & $\begin{aligned} Y= & 188.5+2.51 T+4.34 \mathrm{~L}+1.11 \mathrm{~S}-25.26 \mathrm{H} \\
& -48.19 \mathrm{~A}\end{aligned}$ & 0.965 & 235 \\
\hline (8) & $\begin{aligned} Y= & -432.8+4.14 T+10.81 \mathrm{~L}+80.67 \mathrm{H}- \\
& 0.0032 \mathrm{~T}^{2}+0.0130 \mathrm{~L}^{2}-12.07 \mathrm{~A}^{2}- \\
& 0.0367 \mathrm{TL}+0.00736 \mathrm{TS}+0.0236 \mathrm{LS}- \\
& 0.219 \mathrm{HS}\end{aligned}$ & 0.988 & 178 \\
\hline (9) & $\begin{aligned} Y= & 316+2.8 T+6.6 \mathrm{~L}+1.1 \mathrm{~S}-58.4 \mathrm{H}+1.1 \mathrm{D} \\
& -45.4 \mathrm{~A}\end{aligned}$ & 0.982 & 234 \\
\hline
\end{tabular}

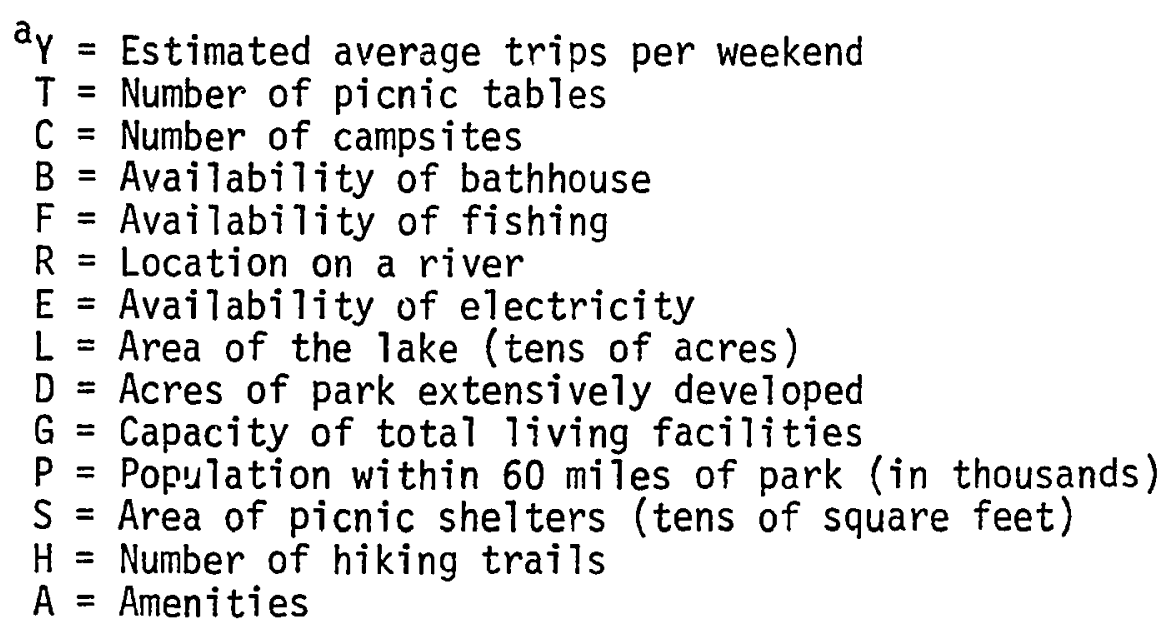


These equations represent "attractiveness" of parks (Ungar, 1967). There is no explanation offered for the negative coefficients associated with some of the variables. The equations assume a linear relation between the various physical attributes of the parks and the "attractiveness", represented by the trips attracted to the parks. The equations do not contain any level-of-service variables. Ungar seems to equate the "attractiveness of parks" to the trips attracted. The attractiveness of a recreational area is due to its physical attributes, the recreational activities offered, and the natural aspect of the park (E17is and Van Doren, 1966) while the trips attracted are a measure of usage. Ungar does not offer a measure of attractiveness of recreational area and his model is independent of any level-of-service variables.

Thus, Ungar's model is not consistent and simple. It does not contain any explanatory variables which pertain to preference for a] ternative sites. The $R^{2}$, ranging from 0.926 to 0.988 , is not indicative of the total modeling process, since these values of $R^{2}$ are only for one step of the process. Further, given that he is predicting trip attractors from themselves, it is surprising his $R^{2}$ 's are not 1.00. Hence, Ungar's model is weak on a!l four methodological criteria. Berg et al. Study. Berg and his colleagues (1974 and 1975) developed a travel demand model to assess the impact of outdoor recreation travel by residents of the nine-state Upper Midwest Region (UMR) to places in the States of Michigan, Minnesota, and Wisconsin (Upper Great Lakes Region-UGLR). The travel information, obtained from randomly selected households, was stratified into summer vacation 
and summer weekend groups. Appended to this categorization was the specification of types of the recreational activities undertaken within the Upper Great Lakes Region. The trip generation model specified both the trip productions and attractions submodels as follows:

1. Zonal trip production submode1

Vacation and weekend trips:

$$
\begin{gathered}
P_{i}=\alpha_{1} \quad I N C_{i}{ }^{\alpha} \operatorname{POP}_{i}{ }^{\alpha} A_{i}{ }^{\alpha_{4}} \\
\text { (a) Vacation: } 0.72-0.92
\end{gathered}
$$$$
\text { (b) Weekend: } 0.89-0.90
$$

2. Zonal trip attraction submodel

Vacation trips:

$$
\begin{gathered}
A_{j}=\operatorname{SH}_{j}{ }^{\alpha_{2} \operatorname{REC}_{j}}{ }^{\alpha_{3}} \\
\mathrm{R}^{2}=0.99
\end{gathered}
$$

Weekend trips:

$$
\begin{gathered}
A_{j}=S_{j} \alpha_{2}{ }_{A I} \alpha_{3} \\
R^{2}=0.99
\end{gathered}
$$

where:

$$
\begin{aligned}
& P_{i}=\text { Productions }- \text { trips produced in zone } i . \\
& A_{j}=\text { Attractions }- \text { trips attracted to zone } j . \\
& I N C_{i}=\text { Family income. } \\
& P O P_{i}=\text { Total population of zone } i . \\
& \text { REC }=\text { Total acreage of lakes plus state and federal } \\
& \text { parks in zone } j .
\end{aligned}
$$




$$
\begin{aligned}
& \mathrm{SH}_{j}=\text { Seasonal homes in zone } j \text {. } \\
& \mathrm{AI}_{i}=\text { Accessibility of a dwelling unit in zone } i \\
& \text { to the recreation supply of the GLR. } \\
& \text { defined as: } A I_{i}=\sum_{\frac{s_{j}}{t_{i j}^{d_{s}}}}^{j=1} \\
& \text { for } t_{i j}=\begin{array}{l}
\text { Minimum path travel time from the } \\
\text { centroid of zone } i \text { to the centrojd }
\end{array} \\
& \text { of zone } j \text {. } \\
& S_{j}=\text { A measure of the recreation supply } \\
& \text { in attraction zone } j \text {. } \\
& \mathrm{m}=\text { Total number of attraction zones in }
\end{aligned}
$$

$$
A I_{j}=\sum_{\frac{n}{\frac{P O P_{i}}{t_{i j}}}}^{i=1}
$$

$$
\begin{aligned}
& \text { for } P_{i}=\text { Total population of zone } i . \\
& n=\text { Total number of zones in UMR. } \\
& \alpha_{1}=\text { Coefficient. } \\
& \alpha_{2-6}=\text { Exponents. }
\end{aligned}
$$

The trip productions were then distributed using the gravity distribution mode1.

Because the form of the 'gravity' model does not guarantee that for a given attraction zone: 


$$
\sum_{i=1}=A_{j}
$$

an interative procedure is employed to adjust the trip interchanges ( $T_{i j}$ ) until a reasonably close balance exists between the calculated trip attracted $\left(A_{j}\right)$ to a zone, and the specified trip attractions for that zone (Berg et a1., 1974, p. 53).

$R^{2}$ values were not given for this second phase of the process.

This model does not contain any policy variables. Berg acknowledged this and suggested that additional research should be focused on the development of improved trip attraction models which would be sensitive to both the quantity and quality of the recreation attractions (Berg et al., 1974 and 1975). Even though the level-of-service variable, time, was introduced into the process, it was not sufficient to account for the spatial gradient effects. As in the previous model, the attractiveness of the GLR recreational areas is not accounted for adequately. Seasonal homes (SH) and lake acreage (REC) are the only variables that represent the attractiveness.

The Berg et al. modeling effort suffers from the same weaknesses as Ungar's model. Their model is not simple, lacks level-of-service variables, and does not reflect users preference with respect to recreational site selection. As in the case of Ungar's study, the value of $R^{2}$ is not for the total modeling effort, but is for the trip generation step. Although an attempt was made to include a level-ofservice variable, time, in the model, the modeling effort is weak on all four criteria. 
Deacon et a7. Study. Deacon et a1. (1973) investigated certain distribution flow models in a study involving outdoor recreation areas in Kentucky. The travel data used were gathered during the summer of 1970. Both the traditional and direct approaches were used. The direct approach was based on a variant of the gravity model (to be discussed 1ater). For the traditional approach, trips produced (productions) at each origin zone and trips attracted (attractions) to each destination zone were estimated using regression techniques. These trip ends constituted one of the input data for the distribution models that were investigated.

The two trip generation equations were as shown below:

1. Productions $\left(P_{i}\right)$

$$
\begin{aligned}
& P_{i}=\alpha_{1} \operatorname{POP}_{i} \alpha_{A R_{i}} \alpha_{I_{i}} \alpha_{4} \\
& \text { (out-of-state zones) } \\
& P_{i}=\alpha_{1} \operatorname{POP}_{\mathbf{i}}{ }^{\alpha_{2}} \operatorname{AR}_{\mathbf{i}} \alpha_{3} \\
& \text { (in-state zones) }
\end{aligned}
$$

where:

$$
\begin{aligned}
P_{i} & =\text { Productions of origin zone. } \\
P_{\mathbf{i}} & =\text { Total population of the zone (in millions). } \\
I_{i} & =\begin{array}{l}
\text { Income per household of the origin zone (in } \\
\text { T,000 dollars). }
\end{array} \\
A R_{i} & =\begin{array}{l}
\text { Accessibility of origin zone to Kentucky re- } \\
\text { creational areas (in millions of accessibility } \\
\text { units) and defined as: }
\end{array}
\end{aligned}
$$




$$
\begin{aligned}
A R_{i} & =\sum_{j}\left(A_{j}\right) \\
\text { for } A_{j} & =\begin{array}{l}
\text { Number of trips attracted to } \\
\text { recreational area } j .
\end{array} \\
F_{i j} & =F \text {-factor of the gravity model. }
\end{aligned}
$$

Additive forms of these equations were also employed.

2. Attractions (A)

$$
\begin{aligned}
A_{j}= & 10.2 \mathrm{GH}+3.28 \mathrm{PIC}+0.3240 \mathrm{~N}+0.0643 \mathrm{DRAM} \\
& +2.24 \mathrm{HIK}+8.17 \mathrm{HB} \\
& +0.293 \mathrm{BEA}+0.227 \mathrm{POOL}+0.0986 \mathrm{LAKE}
\end{aligned}
$$

However, this was reduced to:

$$
A_{j}=4.09 \mathrm{PIC}+0.211 \mathrm{POOL}+0.11117 \mathrm{LAKE}
$$

where:

$$
\begin{aligned}
\text { LAKE } & =\text { Lake acreage } \\
\text { BEA } & =\text { Linear feet of swimming beach } \\
\text { POOL } & =\text { Square feet of swimming pools } \\
O N & =\text { Sum of the numbers of campsites, cottages, } \\
\text { GH } & =\text { and motel or lodge rooms } \\
\text { PIC } & =\text { Number of picnic tables } \\
\text { DRAM } & =\text { Number of drama seats } \\
\text { HIK } & =\text { Miles of hiking trails } \\
H B & =\text { Miles of horseback trails }
\end{aligned}
$$

A multiple form of Equation 5d was considered by these researchers.

Another variable measuring the accessibility $\left(A_{j}\right)$ of recroational area $j$ to population $i$ was defined as follows:

$$
A P_{j}=\sum_{i}\left(P O P_{j}\right)\left(F_{i j}\right)
$$

where:

$$
P O P_{i} \text { and } F_{i j} \text { as defined above. }
$$


Unfortunateiy, this variable was omitted from the analysis since

the quality of the physical environment because of its
negative coefficient in the additive form and negative
exponent in the multiplicative form of these equations
(Deacon et al., 1973, p. 49).

However, this is the only variable that could have provided a means to introduce into the "attraction" term the level-of-service variables. Using the estimated $P_{j}$ and $A_{j}$, and the values of $F_{i j}$ and $L$, the gravity and opportunity models were applied iteratively until "best simulation of the actual $0-D$ trip interchanges" resulted with $R^{2}$ of 0.52 and 0.40 for the gravity and opportunity models respectively. ${ }^{7}$ However, the total values of $R^{2}$ for the entire process (trip generation and distribution) were $0.58(0.92 \times 0.52)$ and $0.37(0.92 \times 0.40)$ for the gravity and opportunity models respectively. Although the level-of-service variable, time, was introduced in the $P_{i}$ as accessibility, it was abandoned because of its negative coefficient in the additive form of $P_{i}$ equation and negative exponent in the multiplicative form of the same equation. The trip attraction equation $\left(A_{j}\right)$ contains an enormous number of the explanatory variables, but no users preference variable is introduced. $A R_{i}$ and $A P_{j}$ are probably the only variables that could be affected by a policy through the $\mathrm{F}_{i j}$; however, these were not used as noted above.

Thus, this model presents the same weaknesses as the Berg model with respect to simplicity, users preference and performance criteria.

$I_{L}$ : This refers to the probability density. See Appendix C. 
Direct Models

Deacon et a1. Study. The direct travel demand developed by Deacon et a1. (1973) is:

$$
v_{i j}=K_{1} \text { DIS }_{i j}{ }^{K_{2}} \operatorname{POP}_{i}^{K_{3}} A_{j} K_{4}
$$

where:

$$
\begin{aligned}
& V_{i j}= \begin{array}{l}
\text { Vehicular trips between recreational area } j \text { and } \\
\text { origin zone } i .
\end{array} \\
& D_{i j}= \begin{array}{l}
\text { Distance in miles between the recreational area } \\
\text { and the origin zone. }
\end{array} \\
& \mathrm{POP}_{j}= \text { Population of the origin zone in } 1,000 . \\
& A_{j}= \begin{array}{l}
\text { Estimated attractions (trips attracted) to recrea- } \\
\text { tional area } j .
\end{array} \\
& \mathrm{K}_{2-4}= \text { Exponents. } \\
& \mathrm{K}_{1}=\text { Coefficients. }
\end{aligned}
$$

Note: $A_{j}$ does not represent the attractiveness of the area but the amount of usage (number of trips attracted); this holds true for the $A_{j}$ of the sequential approach (discussed earlier).

The $R^{2}$ value was 0.40 for this process. As with the traditional approach, the attractiveness of a recreational area is represented by a measure of usage (trips attracted). The model reflects onily one aspect of outdoor recreational travel behavior that of spatial gradient effects based on distance alone. This does not discriminate between time and travel costs, and, in turn, does not allow for adequately assessing transportation system alternatives. As noted above, a linear relationship is assumed between the trips attracted to a park and the physical characteristics of that park. This is not substantiated by prior research on outdoor recreation travel demand 
(Michaels, 1974). The structure of this model assumes that as the distance $\left(D_{i S}\right.$ ) between the recreational areas and the origin zone decreases, the amount of trips $\left(v_{i j}\right)$ increases. However, as the distance approaches the value of zero, the number of trips tends to go to infinity or give unreliable estimates of the demand.

This model is simple and consistent with respect to a spatial gradient effect based on distance. But it does not reflect users preference as an explanatory variable. Hence, it is weak in that respect and its $R^{2}$ is only 0.40 . This is a relatively weak performance.

Thompson Study. A similar structure was employed by Thompson (1967) in studying the flow of campers to a sample of Ontario (Canada) provincial parks. Unlike Deacon, Thompson recognized the importance of representing park attractiveness as a measure of the park's physical attributes rather than as a measure of park usage. He used a concept, referred to as park capacity, to represent this variable. The park capacity was defined as the number of campsites multiplied by the average number of campers in a party.

This model presents some possibilities for a site alternative analysis since a change in the number of campsites at a given campground could lead to a variation in the "park capacity" value. This, in turn, cculd affect the attendance rate. However, it still contains the same limitations as those mentioned in Deacon's direct approach mode1. The value of $R^{2}$ for Thompson's model was 0.65 . Thompson's modeling effort is limited with respect to the users preference criterion. 
Matthias and Grecco Study. A simplified variant of Thompson's model structure was proposed by Matthias and Grecco (1968) as a result of their study of the travel patterns to three parks (reservoirs) in Indiana. The structure of this model is:

$$
Y=A e^{-B X}
$$

where:

$$
\begin{aligned}
& Y=\begin{array}{l}
\text { Trips per } 1,000 \text { population from a county } \\
\text { to a reservoir, the trip rate. }
\end{array} \\
& A=Y \text { intercept of non-linear regression curve. } \\
& \mathrm{A}=\text { Base of natural logarithms. } \\
& B=\begin{array}{l}
\text { Rate of change of non-linear regression } \\
\text { curve. }
\end{array} \\
& X=\begin{array}{l}
\text { Distance in tens of miles from a county to } \\
\text { a reservoir. }
\end{array}
\end{aligned}
$$

This structure was derived by plotting the trip rates against the distance of various counties from a reservoir. The plot produced a straight line on a semilogarithmic graph. Boating, swimming, picnicking, and camping were the activities considered. The model reproduced over 95 percent of the total trips. Again, only spatial gradient effects are measured. Even though the model shows a high value of $R^{2}$ (up to 0.97 ), it has a methodological weakness, that of the users preference criterion.

\section{Conclusions}

The deficiencies related to the selected outdoor recreation travel demand models are shown in Table 1. This table summarizes the criticisms stated in preceding pages. 
TABLE 1

METHODOLOGICAL DEFICIENCIES

\begin{tabular}{|l|c|c|c|c|c|}
\hline \multirow{2}{*}{$\begin{array}{l}\text { Modeling } \\
\text { Approach }\end{array}$} & Model & \multicolumn{4}{|c|}{ Methodological Criteria } \\
\cline { 2 - 6 } & Ungar & 1 & & 3 & 4 \\
\hline Traditiona1 & Berg et al. & $X X$ & $X$ & $X X$ & $X$ \\
\hline & Deacon et ai & $X$ & & $X X$ & $X$ \\
\hline & Deacon et al. & & & $X X$ & \\
\hline Direct & Thompson & & & $X X$ & \\
\cline { 2 - 6 } & $\begin{array}{c}\text { Matthias and } \\
\text { Grecco }\end{array}$ & & & $X X$ & \\
\hline & & & & $X X$ & \\
\hline
\end{tabular}

For $x$ : Serious deficiencies with respect to the corresponding criterion.

$\mathrm{XX}$ : Severe deficiencies with respect to the corresponding criterion.

and Methodological criteria:

1. Internal Consistency

2. Simplicity

3. User Preference Information

4. Performance

It is clear at this point that while there is considerable literature in this area, the operationai models developed to predict travel behavior fail on a number of methodological criteria. 
CHAPTER III

PROPOSED EXTRAURBAN RECREATION TRAVEL DEMAND MODEL

I. CONCEPTUAL STRUCTURE

Outdoor recreationists constitute an heterogeneous subpopulation with respect to their socio-economic attributes (ORRRC, Study Report \#19, 1962), travel time budget constraints (Zahari, 1974; Lisco, 1974), perception of site attributes, responsiveness to the transportation level-of-service and other factors influencing travel behavior (Hauser, 1962; Lime, 1972; Deacon et a1., 1973; Thompson, 1967; Catton, 1969). Some or all of these attribute differentials should be considered in postulating the model structure consistent with methodological criteria elaborated earlier. In addition to these attribute differentials, the model would be most useful as a planning tool if it includes elements affected by variables exogeneous to but influencing travel behavior, e.g., fuel pricing, attributes of the sites, transportation level-ofservice variables.

The direct analytical structure of the travel demand function can best meet the requirements of internal consistency. An exponential form, which is a non-linear functional form, seems to conform best to the existing factual information on outdoor travel behavior, mainly that of spatial gradient effects: the demand for travel declines exponentialiy with the travel time and cost. Also, the appropriateness of the nonlinear form of the equation was arrived at by plotting the trip frequency on selected independent variat? les, e.g., income, distance and time. The non-linear relationships were consistent but not the same 
for all variables. These results are consistent with prior findings (Mueller and Gurin, 1962; Crevo, 1963; Van Doren, 1966; Volk, 1965; Matthias and Grecco, 1968; Clauson and Knetsh, 1962).

The direct structure and the exponeritial functional form were adopted to modify the travel demand function as stated in Equation 1 on page 9 . The variables $A$ (destination) and $S$ (conditions at the origin) were respectively replaced by a destination choice function, as defined below, and the population, characterized by urban place of residence. The level-of-service variables $(L)$ which include travel time and cost are introduced in exponential form (B1ackburn, 1970).

These modifications and specifications of Equation 1 result in the proposed model whose generic functional form is expressed below:

$$
T_{i j}=\alpha_{1} p_{i} \alpha_{2} \alpha_{3} e^{\alpha_{4}\left(a_{i j}+k t_{i j}\right)}
$$

where:

$$
\begin{aligned}
\alpha_{1-4} & =\text { Model parameters, empirically determined. } \\
P_{i} & =\text { Population at origin } i . \\
A_{j} & =\begin{array}{l}
\text { Propensity to attract recreationists to a site: } \\
\text { by users/potential users. }
\end{array} \\
e & =\text { Base of natural logarithm. } \\
T_{i j} & =\text { Trip interchanges between points } i \text { and } j . \\
i-j & =\text { Two spatially distinct locations. } \\
a_{i j} & =\text { Transportation cost incurred during travel bet- } \\
t_{i j} & =\text { Travel } i \text { and } j .
\end{aligned}
$$




$$
\begin{aligned}
k & =\begin{array}{l}
\text { Constant }- \text { rate of substitution between } a_{i j} \\
\text { and } t_{i j}
\end{array} \\
\left(a_{i j}+k t_{i j}\right) & =\text { Generalized travel cost. }
\end{aligned}
$$

Although camping is the recreational activity investigated here, the form of the above equation is quite general and may be applied to any type of recreation occurrence category or recreational activity. It does not specify certain travel decision elements, e.g., the choice of whether to travel or not and when to travel. This model form can be expanded to include these aspects via the $P_{i}$ and $A_{j}$ or separate models can be derived.

Operationalizing this model for prediction of travel demand for the purpose of camping requires gathering several sets of data. Two types of data were used: (1) compiled data from secondary sources; and (2) survey data. All data utilized in the development of this model are compiled data except for data dealing with the site's attractiveness, $A_{j}$, variable.

The form of this model comprises four distinct components:

1. Trip interchanges between points $i$ and $j\left(T_{i j}\right)$.

2. Population at the origin $\left(P_{i}\right)$.

3. Propensity to attract recreationists (destination choice): attractiveness of the site $\left(A_{j}\right)$.

4. Measure of travei impedance - spatial gradient $\left(a_{i j}+k t_{i j}\right)$.

The remainder of this chapter deals with the specifications and/or definition of each of these four components. Compiled and survey data pertaining to each of these components are detailed in the respective subsections. 


\section{COMPONENT SPECIFICATIONS}

Trip Interchanges, $T_{i j}$

Definition. Trip interchanges, $T_{i j}$, are round trips and constitute the travel demand between each origin ( $i$ ) and each destination point $(j)$. They are the dependent variable in this model building process and are annual trips for the purpose of camping. The origins are Oregon urban areas of 10,000 persons or more. Due to their sizes, Portland, Eugene/Springfield and Salem urban centers are subdivided into subareas or traffic analysis zones. Figure 1 shows the urban areas considered, while Figure 2 defines the Portland area and its subareas. Salem and Eugene/Springfield areas and their respective subareas are shown in Figure 3. The destination points are Oregon state campgrounds. Those considered in this study are shown in Figure 4.

Data Sources. Data on observed campground attendances were obtained from a 1975 survey of 39 parks conducted during the summer months of 1975 by the Parks and Recreation Branch of the Highway Division of the Oregon Department of Transportation. The survey forms were filled out by the park users and contained questions about place of residence, income, expenses incurred within a $25-m i l e$ radius of the park and education levels, and other items related to park facilities and services. Of these 39 parks, 30 were either campground and/or both day use and campground areas.

Approximately 22,334 completed survey forms were obtained for both day use and campground areas. Of these, a total of about 6,580 camper observations were usable and coded. This constitutes a 59 percent survey return for the campground users. This sample represents 


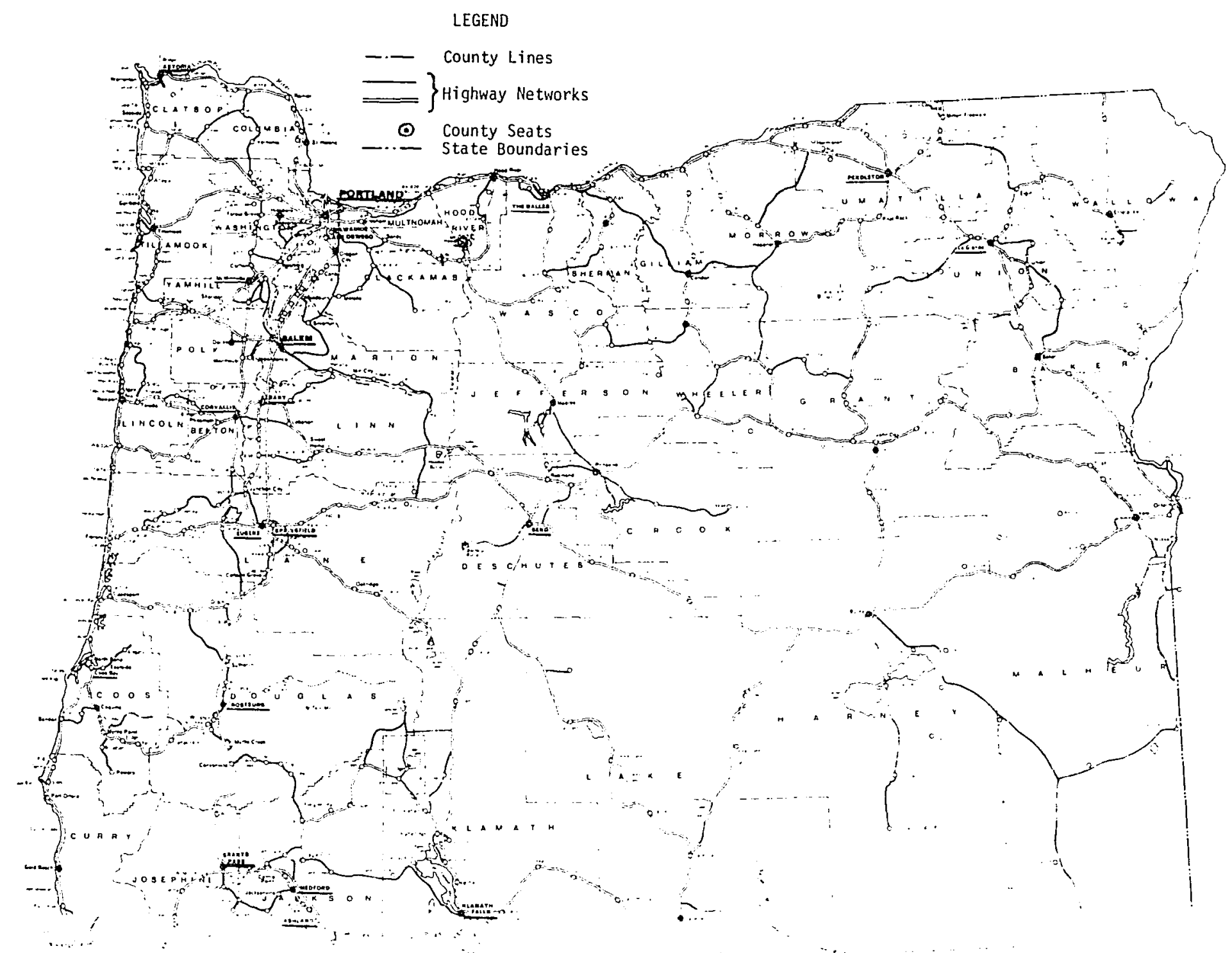

Figure 1. Hap showing urban centers (underscored) of 10,000 or more persons for the statewife mode?. 


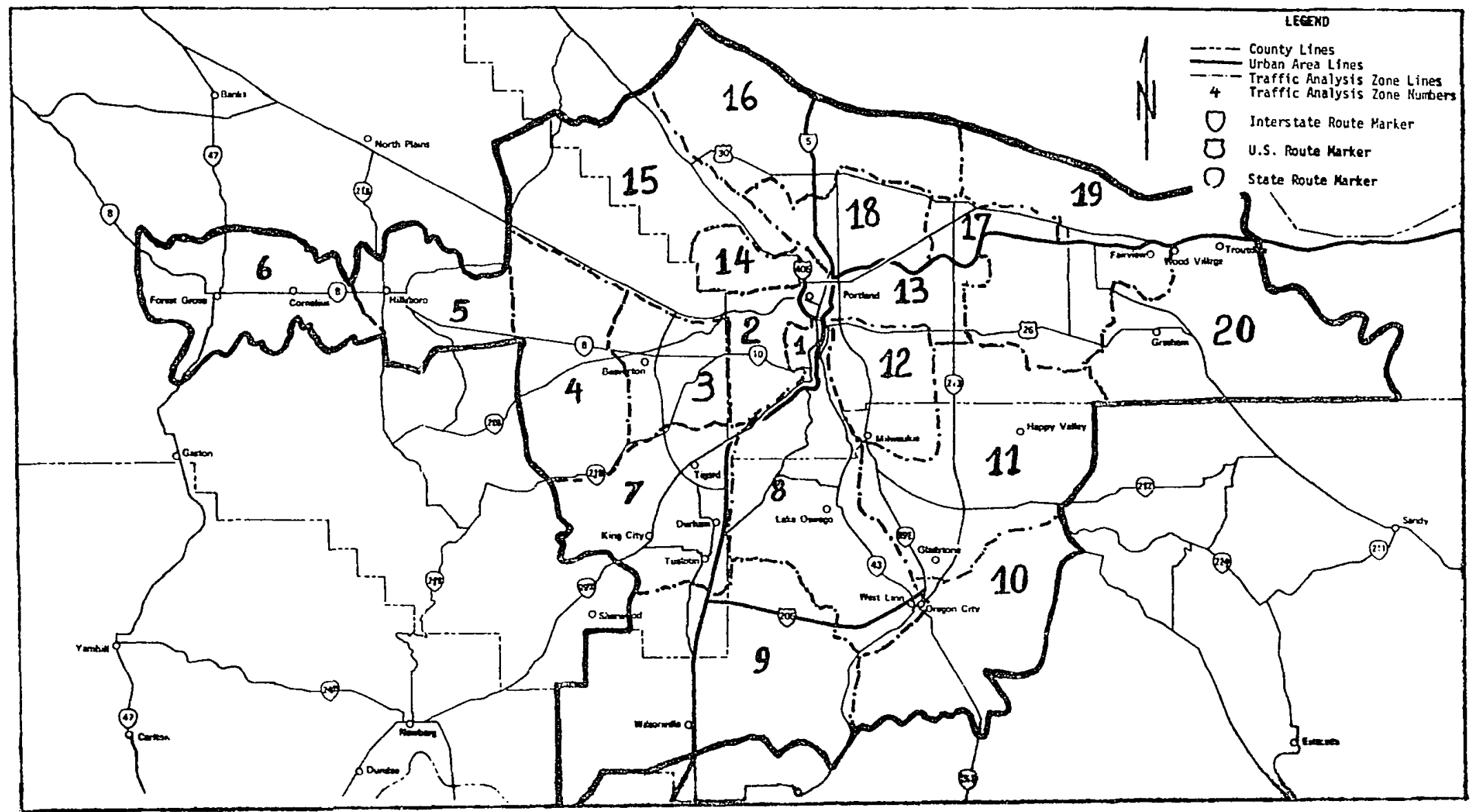

Figure 2.- Map showing Portland subareas considered in Portland model. 


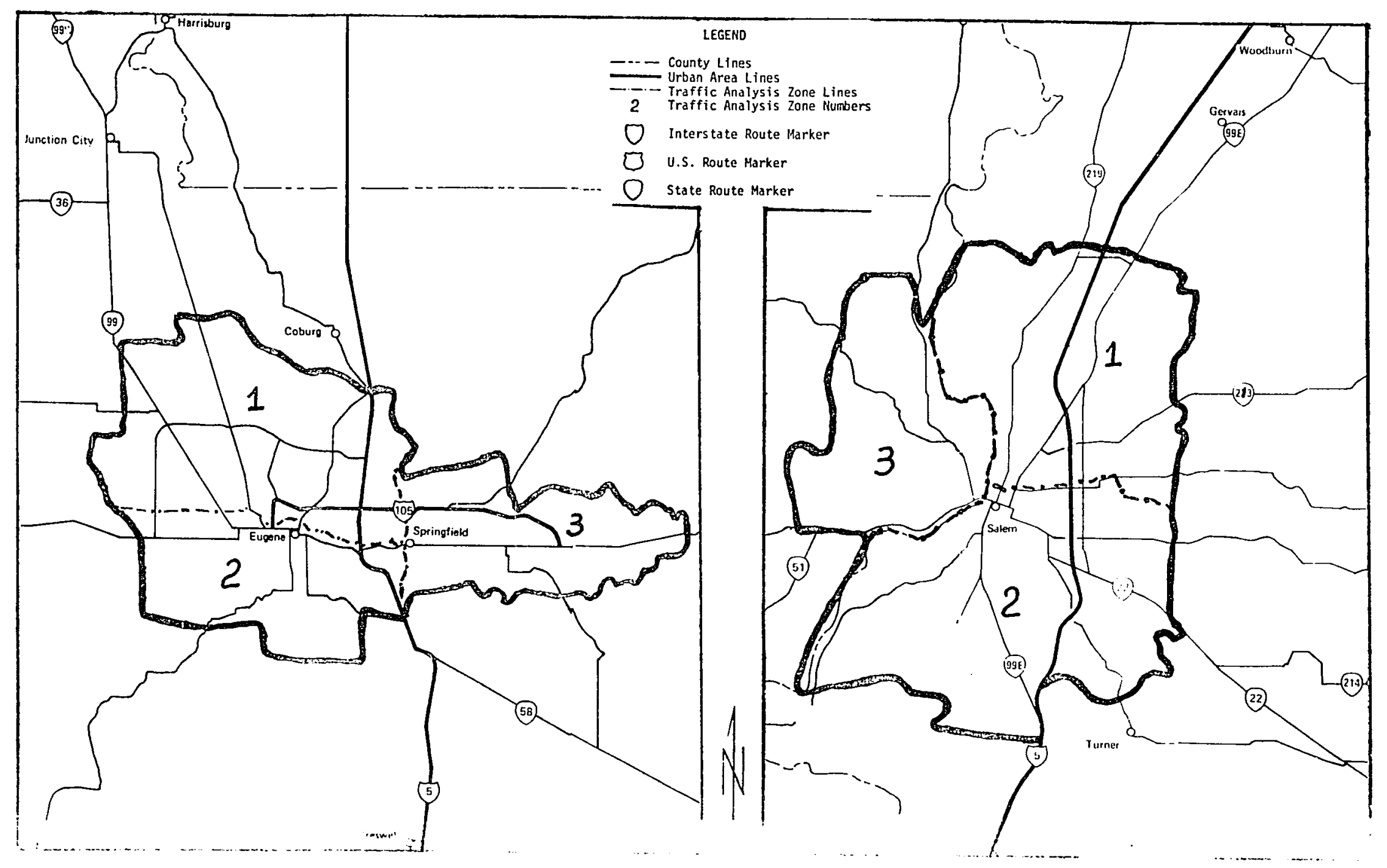

Figure 3. Map showing Eugene/Springfield and Salem subarea:s considered in the statewide model. 


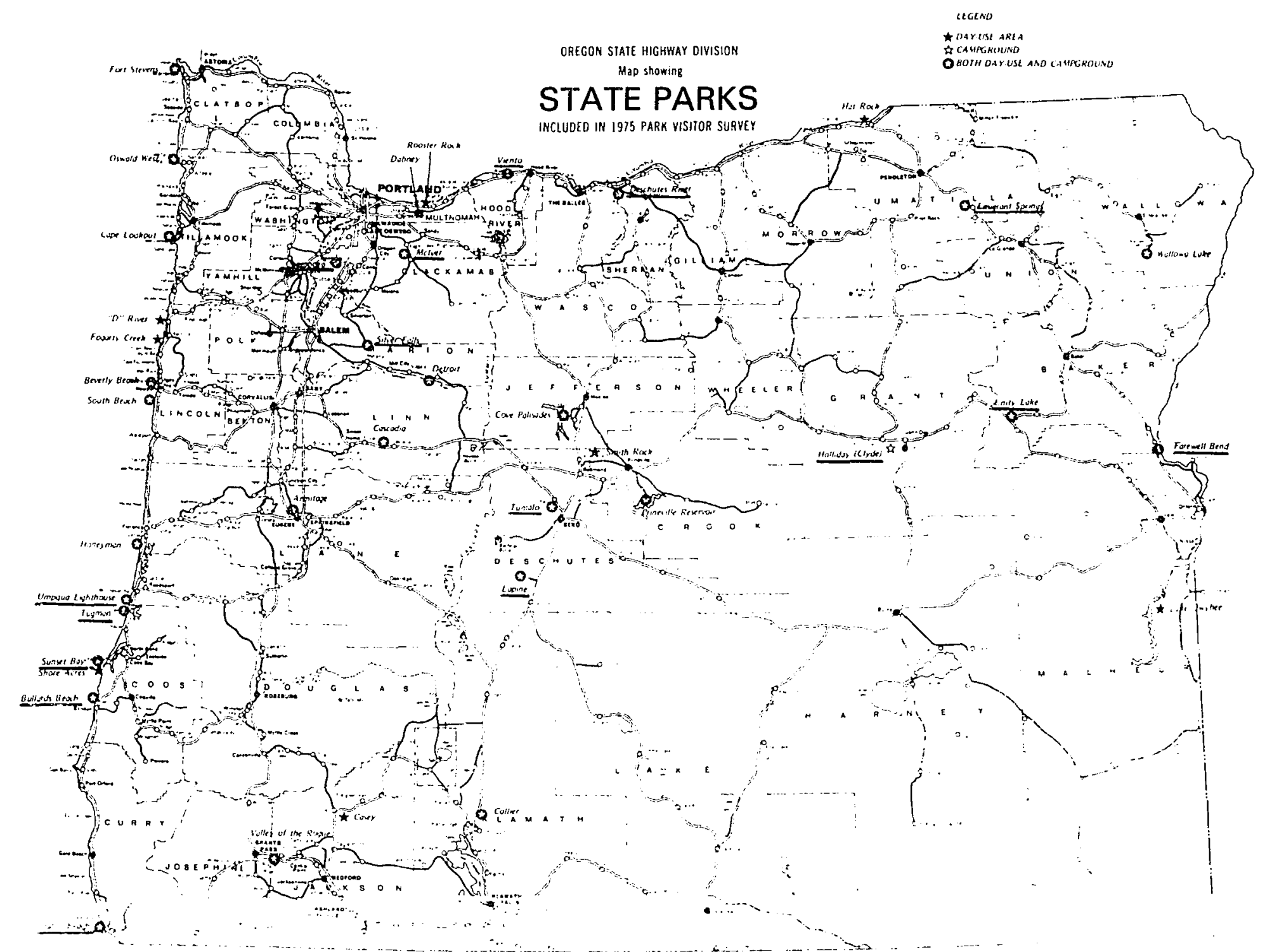

Figure 4. Map showing recreational sites (underscored) considered in the Portland and statewide models. 
approximately 0.94 percent of the Oregon urban resident campers, and 0.48 percent of the Oregon campers as of July, 1975. The distribution of the survey forms to the 39 parks was based on the past visitation rate to each park. A quota was assigned to each park on the basis of this rate. This quota was further partitioned into weekday and weekend portions using the park daily attendance frequencies. ${ }^{1}$

In addition to these data on campground attendances obtainea from the 1975 survey, the Parks and Recreation Branch maintains registrations of campground users at 56 state campgrounds. The 30 campgrounds included in the 1975 survey are part of this group. Campers are requested to provide travel information such as their county of residence and length of stay at the site. This information is compiled on a yearly basis.

The campground attendances from the 1975 survey and the registration information were used to derive the trip interchanges, $T_{i j}$, between each urban area/subarea and each campground under consideration. Appendix D provides the procedures utilized in this process. Due partialiy to the small number of campground attendances obtained from the survey at certain campgrounds, on $1 y 16$ campgrounds were retained in the process of building this model (see Figure 4). Other reasons for this limitation pertain to the site's attractiveness component. This is discussed in detail in the next chapter where variables comprising this component are detailed.

TDue to fluctuation in the daily attendance frequencies, the week was divided into weekday period, ranging from Monday through Friday, and the weekend period comprising days from Friday afternoon to Monday morning. 
Population Variable, $P_{i}$

Definition. The population variable, $P_{i}$, addresses urban areas of 10,000 persons or over as of 1975 (see Figure 1). Portland, Eugene/ Springfield and Salem urban centers were subdivided into subareas (see Figures 2 and 3 ). As mentioned earlier, this subdivision process was induced by the geographic feature of these urban areas.

Data Sources. The population data were derived from 1975 estimates of the population of Oregon and large cities by the Center for Population Research and Census, Portland State University, Portland, Oregon, and Oregon population forecasts by Bonneville Power Administration, Portland, Oregon. These data were allocated to subareas of Portland, Salem and Eugene/Springfield by the Economic Services Section of the Oregon Department of Transportation. A mean annual income of alt families and unrelated individuals was derived for each of these areas and subareas. Extrapolated 1970 census data were used for this purpose, with adjustments due to inflation. The urban area and subarea population and mean income constitute the conditions at the origin variables (S), as stated in Equations 1 and 8 on pages 9 and 39 respectively.

Site Attractiveness, $A_{j}$

Definition of the Destination Choice Function. The $A_{j}$ represents the attractiveness of a site. This variable is a composite one; its components are empirically derived. It is regarded as a measure representing a recreational destination choice for camping activity. As noted on pages 17 through 18. several factors can influence this. Among them are the natural aspects of the site, the physical attributes of the 
site and the recreational activities provided at that site and associated with camping activity (Lime, 1972 and 1972; Thompson, 1967; Eilis and Van Doren, 1966; Marans, 1972). These factors may also be said to determine the recreational space and constitute a basis for selecting a recreation destination. In general, "destination choice involves the choice of a location at which to conduct short-duration and also long-duration activities" (Burnett, 1974, p. 208). Selection of a destination is then a locational choice. The space of concern is the set of campgrounds of the Oregon State Park System.

Postulated frameworks on group as we 11 as individual decision processes for selecting one element (destination) from a set of destinations have been advanced by Wilson (1970), Beckmann and Golob (1972), Horton and Reynolds (1970) and others. However, these frameworks are limited to travel purposes other than recreational.

A spatial choice model which deals with recreational and other destination choices was reported by Burnett (1974). This model combines "functions describing individual and group perceptions of alternatives, ... , preference functions, probability of choosing each alternative, and the relative frequency of trips . . " (Burnett, 1974, p. 215) in one single spatial choice function. A continuous and additive functional form was suggested to relate the perception and preference functions and choice probabilities, but a theoretical basis of this function is not defined, and this model is not operational yet (Burnett, 1974). 
The $A_{j}$ is a variant of the above model in the sense that the selection of a destination is based on preference for factors which describe alternative destinations. However, it differs from the former in that: (1) the probability as well as the trip frequency elements are not applicable to the present modeling effort since the $A_{j}$ is deterministic; (2) the present model is based on the direct aggregate structure, rather than a sequential one; and (3) the perceived factors determining the recreational space (alternative destinations) are those identified by Rushton (1969, 1971), Lime (1971, 1972), Catton (1969) and Marans (1972). Measurement and computational problems may arise from including all these factors in the derivation of $A_{j}$ (Burnett, 1974). Moreover, some factors, although important, might not be amendable to change by policy, e.g., the natural aspects of a site. Hence, only two factors were considered in this study. These are: physical attributes of a site and activities provided at that site, in addition to camping.

The attractiveness of a site, $A_{j}$, is derived from preferences for the objective attributes associated with the above factors, that is, the physical attributes of a site and the recreation activity mixes provided at that same site. This can be mathematically formulated as:

$$
A_{j}=\underset{\text { attributes) }}{f[\text { (activity mixes), (site alternative }}
$$

where:

$$
\begin{aligned}
A_{j} & =\text { Attractiveness of a site, preferences. } \\
f & =\text { Some function. }
\end{aligned}
$$


The attractiveness of a site, defined by the equation above, relates both the objective attributes of the factors describing a site (destination) and the potential users' preference behavior (subjective information) with respect to the destination choice. This equation represents the destination choice function. It comprises two components or sets of subjective values--preferences. One component establishes a preferred alternative mix of recreational activities (MA) while the second is the result of preferences for alternative site attributes $(S A)$. These two components are then related in an additive functional form. Thus, the above function can be rewritten as follows:

$$
A_{j}=(k)(M A)+(c)(S A)
$$

where:

$$
\begin{aligned}
& k=\text { Activity mix coefficient. } \\
& c=\text { Site attribute coefficient. }
\end{aligned}
$$

The $k$ and $c$ coefficients are weights. They were empirically derived from the relative importance placed on the site's physical attributes and mixes of activities by potential recreationists. These weighted subjective values represent the preference that a subject would have for visiting the described site for the purpose of camping. They constitute a proxy for the site's attractiveness index, $A_{j}$, as related to camping recreational activity. This index of site's attractiveness is an aggregate perceived attractiveness for each site. The urban recreationists, engaged in camping at a particular park/site in Oregon, are assumed to have a common subjective utility function with respect to the alternative destinations based on the alternative site attributes and mixes of activities provided at that site (Levine ei al., 
1975; Burnett, 1973; Rushton, 1969, 1971).

Activity Preferences. Four extraurban outdoor recreation activities were considered in combination with camping: picnicking, hiking, fishing and motor boating. These activities were selected on the basis of park visitor survey responses. ${ }^{1}$ Campers were asked to indicate the activities that they were engaged in while at the park. The categories used were those behaviors most frequentiy mentioned, excluding a nebulous activity called "relaxation". These selections are consistent with the findings by Lime (1972), Marans (1972), and Mueller and Gurin (1962).

Site Preferences. Site preferences were based on the number of campsites in a campground, the cost of using a site, and the distance to "other activities". ${ }^{2}$ The cost of the site, in addition to being an economic factor, is also indicative of the degree of wilderness present as the rates are graded by levels of improvement, e.g., primitive sites cost $\$ 2.00$; unimproved cost $\$ 3.00$; and improved cost $\$ 4.00$.

Data for Activity and Site Preferences. The data for determining the exact structure of this composite variable were gathered by a survey of Portland, Oregon, residents in the spring of 1976 . The exact nature of the survey forms and sample are reflective of the techniques of psychometric measurement used to derive MA and SA. Hence, it will be detailed after a discussion of these techniques.

From the 1975 State Park Survey carried out by the Parks and Recreation Branch, Oregon Department of Transportation.

${ }^{2}$ The "other activities" refer to the four activities included in the mix of activity component (MA). 
Data on the activity and site attribute variables used in the calibration and example application were derived from the Parks and Recreation Branch records for the appropriate campgrounds as of 1975 .

Generalized Costs $\left(a_{i j}+k t_{i j}\right)$

Definition. The expression $\left(a_{i j}+k t_{i j}\right)$ is the generalized cost. It is composed of the two level-of-service variables: travel costs and travel times. These have been assumed to take the following values rather than deriving them from a survey: $t_{i j}$ is travel time from $i^{\text {th }}$ origin to $j^{\text {th }}$ destination, while $a_{i j}$ is a modal travel cost from $i^{\text {th }}$ origin to $j^{\text {th }}$ destination. This modal cost is the actual cost of auto travel. This includes the cost of gas and insurance, and the depreciation and maintenance costs. The $t_{i j}$ are also modal dependent. Since the automobile is the mode of concern, these trave 1 times were derived directly from the highway network. In this study, the value of $k$, the rate of substitution between time and cost, is assumed to be equal to one (B1ackburn, 1970). Even though the tripcost function must necessarily be linear, travel demand is required to decline exponentially with the generalized trip cost (ibid). Procedures for computing the expression $\left(a_{i j}+k t_{i j}\right)$ follow.

Recall that the expression $\left(a_{i j}+k t_{i j}\right)$ of Equation 8 is the generalized cost. The component $t_{i j}$ does not require supplementary notes; however, $a_{i j}$ is a resultant variable of several components as explained below. 
Let $\quad a_{i j}=[(M) /(\gamma)] /[(x)(R)]\left(\frac{\min }{\operatorname{mile}}\right)$

where:

(1) $R=$ Rate of annual expenditure for the purpose of taking part in recreational activities; it includes transportation costs. It is expressed in percent

(2) $\gamma=$ Fuel (gasoline) availability coefficient expressed as a rate.

(3) $M=$ cost of operating a vehicle. It includes fuel, depreciation, maintenance, insurance, - . costs and is expressed in cents per mile driven or traveled.

(4) $X=$ Yearly earnings expressed in cents per minute. These earnings are those for families and unrelated individuals.

Noting that:

$$
\begin{aligned}
& X=\frac{\text { Annual income }\left(\frac{\text { dollars }}{\text { year }}\right)}{2,080\left(\frac{\text { hours }}{\text { year }}\right) 60\left(\frac{\text { min }}{\text { hour }}\right)} \\
&=\frac{\text { Annual income }}{(2,080)(60)}\left(\frac{\text { dollars }}{m i n}\right) \\
&=\frac{\text { Annual income }}{124,800}\left(\frac{\text { dollars }}{\text { min }}\right) \\
&=(100)\left(\frac{\text { Annual income }}{124,800}\right)\left(\frac{\text { cents }}{\text { min }}\right) \\
&=\left(\frac{\text { Annual income }}{1,248}\right)\left(\frac{\text { cents }}{\text { min }}\right)=\frac{Y}{1,248} \quad\left(\frac{\text { cents }}{\text { min }}\right) \\
&\text { for: } \left.2,080 \frac{\text { hours }}{\text { year }}=\left(40 \frac{\text { hours }}{\text { week }}\right) \text { (52 } \frac{\text { weeks }}{\text { year }}\right)
\end{aligned}
$$

and: $Y=$ Mean annual income of all families and unrelated individuals. 
The Equation 11 can be rewritten as follows:

$$
\begin{aligned}
& a_{i j}=\left[(M)\left(\frac{\text { cents }}{\text { mi }}\right) /(\gamma) \%\right] /\left[\left(\frac{Y}{1,248}\right)\left(\frac{\text { cents }}{\text { min }}\right)(R) \%\right] \text { or } \\
& a_{i j}=(M) /\left(\frac{Y}{1,248}\right)(R)(\gamma)\left(\frac{\text { min }}{\text { mi })}\right)
\end{aligned}
$$

To calibrate the Equation 8, the following conditions (values of constants and coefficients in the Equation 12) were observed:

$$
\begin{array}{ll}
\gamma= & 1.00 \text { or } 100 \% \\
R: & \text { Varied between } 6 \text { and } 10 \% . \\
M: & \text { Varied between } 17 \text { and } 20 \text { cents per mile. }{ }^{2} \\
X: & \begin{array}{l}
\text { Varied according to the income variable, } Y, \text { of } \\
\text { each urban area and subarea. }
\end{array}
\end{array}
$$

For instance:

$$
X=8.01282\left(\frac{\text { cents }}{\text { min }}\right)=\frac{(100)(10,000)}{124,800}\left(\frac{\text { cents }}{\text { min }}\right)
$$

where:

$$
\begin{aligned}
& Y=\$ 10,000 \text { (for a Portland subarea). } \\
& \text { and: }(\gamma)(X)(R)=0.80128 \text {, for } R=10 \text { and }=1.00 \\
& \text { or } 100 \% .
\end{aligned}
$$

Then, $\quad\left(a_{i j}\right)\left(\begin{array}{l}\text { Distance } \\ \text { Traveled } \\ \text { in miles }\end{array}\right)=\left(a_{i j}\right)\left(\begin{array}{l}\text { Distance } \\ \text { Traveled }\end{array}\right)($ min $)$

${ }^{1}$ This rate involves annual expenditure for all recreational activities, including camping. This percentage was approximated from the average expenditure per recreational occurrence as reported by the recreationists during the 1975 State Park Survey referred to on page

${ }^{2}$ See U.S. Department of Transportation, Federa? Highway Administration, "Cost of Operating an Automobile," Apri1, 1974; but modified to account for heavy vehicles used for camping activities. 
where:

$$
a_{i j}=\frac{(M)}{0.8128} \quad\left(\frac{\min }{\operatorname{mine}}\right)
$$

Final1y, $\left(a_{i j}+k t_{i j}\right)=\left(a_{i j}\right)\left(\begin{array}{l}\text { Distance } \\ \text { Traveled }\end{array}\right)\left(\right.$ min) $+k t_{i j}$ (min)

The $a_{i j}$ has been calculated for families and unrelated individuals. It could have been computed on a per capita basis; however, campers were not so differentiated. The $a_{i j}$ values can easily be converted to this basis if so desired and the model should then be recalibrated and $P_{i}$ and $A_{j}$ modified.

Data Sources. To evaluate the generalized cost variable $\left(a_{i j}+\right.$ $k t_{i j}$ ), two data sets were formed: (1) distances (in miles); and (2) travel times. These are distances and travel times from each urban center and/or subarea (see Figures 1,2,3) to each of the campgrounds under study (see Figure 4). They were derived from maps obtained from the Planning Section of the Oregon Department of Transportation.

\section{I. SUMMARY}

To some extent the form of the model is deceptively simple. It would appear one dependent variable is being predicted by three independent ones. In fact, two of the latter three, $A_{j}$ and $\left(a_{i j}+k t_{i j}\right)$, are complex composite variables. The remaining variable, $P_{i}$, could also be specified by origin condition variables; however, the 1975 Oregon Park Surveys did not show any significant differences in the income, occupation, education, etc., of campers from the general state breakdowns. A schematic of the model is depicted in Figure 5. 


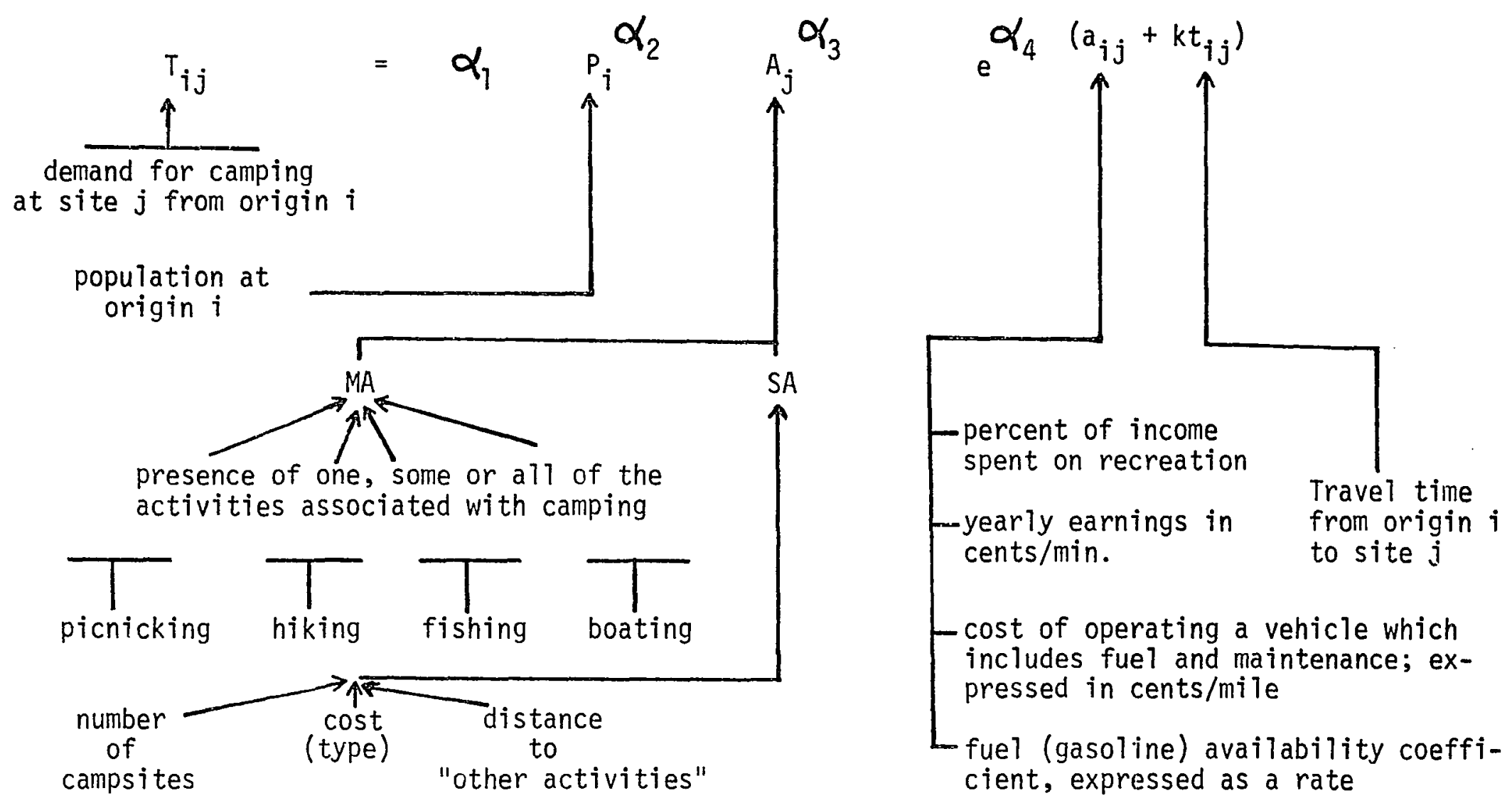

Figure 5. Urban campers travel demand model.

ज 
As noted in the first chapter, calibration and example demonstration of even this prototype model has extensive data requirements. Data from three secondary sources and the primary data derived from the survey constitute the minimum data set to operationalize this model.

A11 of the site attraction variables can be directly and completely controlled through investment strategies. Two components of the impedance variable $\left(a_{i j}+k t_{i j}\right)$ can be indirectly and partially controlled by policy decisions. Fuel costs are, in part, dependent on taxation and, in extreme situation, on rationing regulations. Travel time is dependent on the capacity and condition of roads as well as legal speed limits. If the model performs well, it can be used to project changes in demand with diverse policies with reference to these variables.

Finally, the structure of the model is superior to any single previous one. It conforms to the simplicity and consistency criteria in that it is a direct demand model. It conforms to the empirical derivation criterion in that all independent variables have been shown by past research to be related to camping travel and that the relationship of these variables is derived through preference modeling or consistently applied economic theory. 
CHAPTER IV

DESTINATION CHOICE FUNCTION: METHODS OF EVALUATION

I. INTRODUCTION

As mentioned in Chapter II, travel demand function is defined with respect to measures of mutual attractiveness of origins and destinations, and terms measuring the effort imposed by the impedance of the transportation system. The attractiveness of a destination is represented by a destination choice function (page 47) in this study.

It was established in Chapter II that preferences based on physical attributes of the recreation areas and mixes of recreational activities offered at those areas form the basis for a destination choice. It was also determined in the same chapter that many models previously used to estimate recreational travel demand did not include, as an explanatory variable(s), a preference element(s) in evaluating this destination choice function--site's attractiveness, $A_{j}$. Instead, attractiveness was disaggregated into several explanatory variables, each of which was entered into the function as a separate item. Each of these items was represented in the function by objective, extrinsic or physical measures rather than subjective values attached to the attributes of these variables. This violates the user information/ preference criterion. The proliferation of variables determining the attractiveness function further reduces the likelihood of these models meeting the simpicity criterion. 
Thus, if the $A_{j}$ component of the proposed model is to be favorably considered on evaluation criteria it must enter the equation as a single composite variable. The subcomponents of this composite variable must represent preferences for the site's attributes related to each of the factors previously shown to be important in the selection of a campground (destination choice) by the campers. In Chapter III, it was established that only two factors were considered in this study (page 49). Preferences regarding these two factors were derived as part of this research. The first is related to the activity mixes provided at a park. Preferences are assessed with respect to these alternative mixes of the activities. The second component includes the site' attributes, with preferences scaled with respect to these attributes. Each of these components can be scaled through psychometric procedures for the assessment of preferences and perceptions (Golog et a ., 1974; Michaels, 1974; Burnett, 1974; Dobson, 1974).

\section{COMPARATIVE JUDGMENT TECHNIQUES}

The law of comparative judgment, pair comparison, categorical judgment, ratio scale, and rankings and summated ratings are all formal methods for generating true interval scales of human attitudes and preferences. These techniques have been applied to predicting transportation related choices and decisions. Golog et a1. (1974) report transportation applications of Thurstone's law of comparative judgment-paired comparison to a study of a dial-a-bus system. Steven's ratio scaling was used to model transportation demand, given travel time and the cost of making a trip. Dobson (1974) reports similar 
applications of psychometric procedures to transportation-related problems. These appiications assessed users' responses to transportation system changes.

of the above techniques, paired comparison is best suited to scale the subjective preferences for alternative mixes of activities. The paired comparison does not presuppose transitivity property of the stimuli (Torgerson, 1958); activities are categurica? infurmation, e.g., listings of campgrounds showing the various mixes of activities provided at the campgrounds in addition to camping. The derived preferences for mixes of activities are given on an interval scale according to linear combinations only. Paired comparison tests and transformations of the raw data provide just such scores. The mix of activities is the attribute to be scaled rather than the type and the amount or quantity of the activities.

\section{INFORMATION INTERGRATION THEORY}

Preference scores for campground site/attributes cannot be obtained by the same means. Here, the stimuli under investigation are perceivable on scales which are inherently interval and continuous. For example, the number of other campsites in a campground can range from zero, where one is in a wilderness area and specific locations are not provided, to hundreds in places with large improved grounds. Further, as interval scales for attributes are present, it is possible to combine them in linear or non-linear forms in arriving at preference scores. Establishing the correct form is critical to precise prediction. 
The "functional measurement" technique, as derived from Anderson's work on the integration information theory of judgment, is particularly suitable for this purpose. Appendix E contains essentials of Anderson's approach to jucigment theory and measurement models. The preferences derived through this technique are interval scale values. The information being integrated is contained in the stimuli-attributes (Anderson, 1972). The integration processes resulting in overal1 responses or preferences can be linear or non-linear, additive, averaging, ratio or multiplicative (Anderson, 1972 and 1974). Thus, linear or non-linear integration models that are additive, averaging, ratio or multiplicative in nature can result and the subjective responses are then specified according to the model. The appropriate form varies from case to case.

Mathematically, this amounts to evaluating a function of the following form:

$$
R=f[(w, s), s]
$$

where:

$$
\begin{aligned}
& R=\begin{array}{l}
\text { Subjective response to the stimulus combina- } \\
\text { tion formed from the set } S \text {. }
\end{array} \\
& w=\begin{array}{l}
\text { Weight representing the amount of information } \\
\text { in the stimulus. }
\end{array} \\
& S=\text { Value of the stimulus. } \\
& S=\text { A set of m stimuli, with } S \neq\{\emptyset\} \\
& f=\text { Some function. }
\end{aligned}
$$

and more explicitiy:

$$
R_{i j k}=c+w_{i} s_{j}+w_{j} s_{j}+w_{k} s_{k}
$$


where:

$$
\begin{aligned}
i, j, k= & \begin{array}{l}
\text { Three different attributes belonging to } \\
\text { the set } S \text {. They constitute the stimuli } \\
\text { of three--factor design. }
\end{array} \\
c= & \text { Constant. }
\end{aligned}
$$

The nature of the function, $f$, determines the type of the models, e.g., Equation $13 \mathrm{~b}$ is a linear intergration model. The function itself depends on the nature of the judgment task. Louviere and Norman (1974) used this technique to assess public preferences toward hypothetical bus systems as a function of three transportation system attributes: fare, frequency of service, and walking distance to the bus stop. The purpose was to estimate and predict public response to policy decisions affecting these three attributes. The three attributes were combined in a $3^{3}$ factorial design to obtain 27 stimuli representing 27 different bus systems. The subjects were instructed to treat each of the 27 stimuli independently in their rating of the systems. Two types of the models were applied to the responses:

$$
R_{i j k}=\alpha_{1}+\alpha_{2} x_{i}+\alpha_{3} x_{j}+\alpha_{4} x_{k}
$$

an additive linear integration model

(2) $\quad R_{i j k}=\left(x_{i}^{w_{1}}\right)\left(x_{j}^{w_{2}}\right)\left(x_{k}^{w_{3}}\right)$

a multiplicative integration model

where:

$$
\begin{aligned}
& R_{i j k}= \text { Predicted response for fare } x_{i}, \text { fre- } \\
& \text { quency of service } x_{j} \text {, and proximity } \\
& \text { to the bus stop } \ddot{x}_{k} .
\end{aligned}
$$




$$
\begin{aligned}
& \alpha_{1-4}=\text { Regression coefficients. } \\
& w_{7-3}=\begin{array}{l}
\text { Respective weights; they were assumed to } \\
\text { be equal to } 1 .
\end{array}
\end{aligned}
$$

A policy about the desirability of a particular bus sytem can be formulated and based on the derived subjective ratings obtained by testing the various alternative systems. The role of an attribute is based both on its weight and the form of the function. Other applications of this technique can be found in Anderson's (1972 and 1974) work; however, they address non-transportation judgment tasks.

A major drawback of using this technique is that elaborate and controlled surveys have traditionally been associated with it. For example, a minimal survey booklet for analyzing the integration of three attributes, each of which are present in three levels, involves consideration of 27 combinations of attributes and levels in four separately randomized replications, one for learning and three for analysis. This is a total of 101 evaluations. Often, end-anchors and fillers are used in these surveys. These are values of attributes so extreme as to be practically beyond the behavioral universe in question which are included in the survey to preserve the mathematical integrity of the continuous scales but subsequently dropped from analysis. Adding these dummy items increases the levels of attributes and consequent combinations of attributes to be considered. The average length of interview can easily be 30-35 minutes after a 20-minute orientation. 
As might be expected, surveys of this type have generally been done with small, captive samples. Sample sizes as small as nine and usually no greater than 30 are reported (Anderson, 1972; Louviere and Norman, 1974). One major problem of this research was the adaptation of this technique to self-administered surveys of less controlled, more representative samples. 
CHAPTER $V$

DESTINATION CHOICE FUNCTION: SURVEY DATA

\author{
AND EVALUATION
}

In order to establish the destination choice function, a survey was conducted within the Oregon counties of the Portland SMSA (see Figure 2). Al1 the parameters necessary to evaluate this function are directiy derived from these survey data, that is, preferences for mixes of activities and site attributes, and relative weights relating these preferences in the additive functional form (Equation 10, p. 50 ) of the site's attractiveness, $A_{j}$, are all derived from these survey data.

\title{
I. SAMPLE
}

There were 850 questionnaires distributed among employees of Multnomah County Department of Human Services, Port of Portiand and Northwestern Educational Lab and the Labor Center. The participation was voluntary, and the questions were self-administered.

The subjects were not randomly selected, nor were the agencies. However, all individuals were residents of the Portland urbanized area and employed at the time of sampling. The representativeness of the sample was evaluated, as detailed below, after the forms were returned. While this is a convenience sample, it should be kept in mind that its size is much larger than is usually the case when Anderson's functional measurement is employed. Further, while there were no controls to ensure the sample would be representative of the general Portiand 
population, the employee groups used conform much more closely to this criterion than the student groups often used.

\section{REPRESENTATIVENESS OF THE SAMPLE}

Approximately 225 properly completed questionnaires were retained. The highest percent (60\%) of incomplete and/or improperly answered questionnaires was registered for the functional measurement set. These respondents were stratified by income, education and occupation; the Portland area population was also stratified in a similar manner. For each stratification category, a series of percentages for the sample and population cell frequencies were calculated. The cell percentages from the sample were compared to those from the population for each stratification category. The percentage variations between the city and the sample were within three percent (see Appendix F). The representativeness of this sample for the Portland area population is affirmed; however, it remains that randomness and representativeness were not assured by a priori procedure.

\section{SURVEY FORMS}

The survey forms were in three sections. First was a group of activity mix pairs for comparative preference. Three different subforms were used in this section, each with a randomly selected third of the possible pairings, in order that the length of time to complete the survey would be limited. Details of the paired comparison test structure and results are discussed below. A11 forms had the 27 combinations of campground attributes for evaluation as the second section. 
Again, details are discussed below. The third question set pertained to the socio-economic characteristics of the subjects. It dealt with four variables: income, education, occupation and ZIP code residential location of the subjects. These variables were used to ensure that the sample was representative of the Portland urbanized area population. Also, the subjects were asked to respond to an additional question regarding their recreational travel decision process. The response frequencies to this question was used to weight the two components of $A_{j}$ as in Equation 10. Samples of the questionnaires used to generate the necessary information for the derivation of $A_{j}$ constitute Appendix $G$.

\section{ACTIVITY PAIRS}

A set of 105 pairs were formed from the 15 combinations of the four activities, picnicking, hiking, fishing, and motor boating. This set was randomly partitioned into three subsets of 35 pairs. Each of these subsets was administered to different subjects. Only four activities in addition to camping were considered. This limitation was due mainly to the practical implication: paired comparison becomes impractical as the number of the activities reaches five or more. Using onty the four activities mentioned above, combinations of activities were formed as follows:

$$
c=2^{n}-1
$$

where:

$c=$ Mixes of activities.

$\mathrm{n}=$ Number of activities under consideration.

and $c=2^{4}-1=15$ in this study. 
These combinations were then used to form pairs as follows:

$$
p=c(c-1) / 2
$$

where:

$$
c=\text { Number of mixes of activities. }
$$

and $p=15(15-1) / 2=105$ for $p=$ pairs.

For the four activities retained, 105 pairs resulted. These were randomized into three sets so that every subject need not consider every pair, while an equal number of evaluations of each combination was made over the sample.

The subjects were then asked to indicate their preference for alternative activity mixes which they engage in while camping. This effort was repeated for each pair. The raw data were tabulated into frequencies which indicate the number of times a given mix of activities was preferred over the other and the number of times it was not. These frequencies were arranged in a $R \times R$ square matrix (subsequently referred to as matrix $R$ ) with the rows occupied by the frequencies of preferred mixes and the columns by those which were not. This is a $15 \times 15$ matrix.

The derivation of scale values, subjective judgment values, for the mixes of activities (stimuli) involves a series of transformations of the matrix $R$. This was done according to principles and procedures of least-squares solution for estimating scale values from the matrix $\mathrm{R}$ (Torgerson, 1958). First, the cells (preference frequencies) of matrix $R$ are transformed into proportions, matrix $P$. The symmetric cells of matrix $P$ add to 1.00 and the main diagonal eiements of matrix 
$\mathrm{P}$ are zero. ${ }^{1}$ Appendix $H$ gives the cell values of $\mathrm{P}$. Second, the proportions of matrix $P$ are in turn transformed to unit normal deviates, matrix D, using tables of areas under the unit normal curve with the diagonal elements replaced by zeroes. The elements of matrix $D$ are shown in the Appendix I.

Finally, since the matrix $P$ does not contain vacant cells (except the diagonal elements), the scale values corresponding to the mixes of activities are given by Equation 16 .

$$
\operatorname{MAV}_{k}=1 / n \sum_{j=1}^{n}
$$

where:

$$
\begin{aligned}
\text { MAV }= & \begin{array}{l}
\text { Scale value, corresponding to a given mix of } \\
\text { activities. }
\end{array} \\
x= & \text { Unit normal deviates - derived from matrix } P . \\
n & =\begin{array}{l}
\text { Number of stimuli--mixes of activities, } n=15 \\
\text { in this study. }
\end{array} \\
j, k & =\text { Stimulus indexes. }
\end{aligned}
$$

and the origin for the scale is set at the point where $i / n \sum_{j=1}^{n}=0$ so that

$$
\text { MAV }_{k}=1 / n \sum_{j=1}^{n} \quad \text { for } k=1,2,3, . ., n ; n=15
$$

Let $r_{i j}$ represent any cell of a matrix $R$; then, $r_{i j}$ and $r_{j i}$ are said to be symmetric cells for $i \neq j$, and all the celis for which $i=j$ constitute the main diagonal elements (cells) of matrix R. 
that is the MAV $_{k}$, scale value, is simply the column average (Torgerson, 1958). The MAV $k$ were then ranked as shown in Table II.

TABLE II

RANKED RECREATION MIX OF ACTIVITY SCALE

VALUES, MAV

\begin{tabular}{|l|c|c|}
\hline Rank & Mix of Activity (MA) & MAV \\
\hline & abcd & \\
1 & abc & 0.5564 \\
2 & acd & 0.4578 \\
3 & abd & 0.3723 \\
4 & bcd & 0.3003 \\
5 & bc & 0.2918 \\
6 & ab & 0.0429 \\
7 & ac & 0.0279 \\
8 & cd & -0.0257 \\
9 & bd & -0.0667 \\
10 & ad & -0.0742 \\
11 & b & -0.0974 \\
12 & c & -0.3379 \\
13 & a & -0.3991 \\
14 & d & -0.4274 \\
15 & & -0.5671 \\
\hline
\end{tabular}

Notations:

$$
\begin{aligned}
& a=\text { picnicking } \\
& b=\text { hiking } \\
& c=\text { fishing } \\
& d=\text { motor boating } \\
& k=1,2,3, \ldots . .15
\end{aligned}
$$

The activity mix scale values (in Table II) can be partitioned into four groups: single, two, three and four activity combinations. The mix of four activities is definitely preferred over any other mixes; mixes of three activities are, in turn, preferable over those of two while a single activity is the least preferred. Within groups of mixes of two 
or more activities, the ones containing picnicking as an element of the mix are scaled higher except when motor boating activity is involved. The negative values should be viewed as representing the least preferred mixes of activities in combination with camping rather than repugnance; they may have higher value in contexts other than camping.

Each of the 16 recreational areas (see Figure 4) under consideration is given the corresponding scale value from Table II according to the mix of activities provided at that site. These scale values were multiplied by 100 in order to bring them to the functional measurement scores order of magnitude.

\section{SITE ATTRIBUTE INTEGRATION}

For the site's characteristics, 27 combinations of three site's attributes were established in a $3^{3}$ factorial design. Each combination is a description of a possible camping site. These combinations result from varying three characteristics involved in the selection of a site. These are: (1) the number of campsites (few, several, and many)--reflecting the level of "crowdedness"; (2) the type/kind of campsites (primitive, unimproved, and improved)--reflecting the level of "wilderness"; and (3) the proximity of the campsite to other recreation facilities (nearby, further away, far away)--denoting the "opportunities for a second, third, fourth, or fifth activity paricicipation", or "remoteness from any other activities". Actual numbers were used in questionnaires instead of few, several, many, nearby, further away, and far away. The "other activities" refer to the four recreational activities mentioned above. 
The type/kind of campsites were described as follows: primitive campsites are campsites containing only pit toilets and water; unimproved campsites are those campsites with flush toilets, electricity and water; and improved campsites can contain electricity, hook-up utilities, showers, . ., in addition to flush toilets. There is a differential fee for each campsite type: $\$ 2.00$ for the primitive type; $\$ 3.00$ for the unimproved type; and $\$ 4.00$ for the improved ones.

The three levels of the "crowdedness" attribute are defined with respect to the number of campsites available at a campground. Using the Parks inventory data, a mean number of campsites and standard deviation were calculated. These values were used to establish the three levels (1-50, 51-100, and 101-150) of the "crowdedness" attribute.

The "remoteness from any other activities" attribute is measured in terms of distances from the campground centroids to the location of the "other activities" within the campground; the mean and standard deviation were computed. Using these two values, ranges of "less than a mile", "one mile to two miles", and "two miles to three miles" were established. These ranges represent the three levels of the "remoteness" attribute. Under these conditions, a radius of 2.00 miles excludes a large number of the "other activities" from the campground centroids, while a radius of 3.00 miles tend to isoiate the campsite areas. However, certain parks, due to their geographic locations, contain most of the "other activities" within a mile of the campsite areas. These are campsite areas located by lakes/rivers or other natural features, e.g., Detroit Lake Park. For both "crowdedness" and "other activities" attributes, the ranges were set at one, two and three 
standard deviations from their respective means. This established the ranges for the first, second and third levels of these attributes.

As mentioned earlier, all the 30 campgrounds included in the 1975 Park Survey by the Parks and Recreation Branch of ODOT were not retained here. Only 16 were used in this modeing effort. There are two reasons for this reduction.

(1) Some campgrounds contain large numbers of campsites, wel1 above 300 , and present diverse configurations of the built-up areas of the parks where campgrounds are lecated. This results in excessive variances (skewed distributions) which could not permit the establishment of acceptable ranges of both the "crowdedness" and "other activities" attributes. Parks of that size warrant individualized study apart from the general model.

(2) Survey travel patterns, from subareas of Portland, Eugene/ Springfieid and Salem to certain campgrounds, were too small to allow a reliable derivation of trip interchanges, $T_{i j}$, using campground registration data.

Thus, levels were established using inventory data of only these 16 campgrounds. From these three levels of the three attributes, 27 combinations were formed. Each combination described a possible campground in terms of the three attributes. A11 the 27 combinations were randomized.

The subjects were asked to give a value, between $0 \%$ and $100 \%$, to each of the 27 combinations (see Appendix G). The vaiue represents the likelihood that they would visit the described campsites for the purpose of camping. This subjective score value, shown in Table III is an 
TABLE III

MEAN SUBJECTIVE SCORE VALUES FROM SITE'S ATTRIBUTE INTEGRATION RESPONSES - RAW DATA

\begin{tabular}{|c|c|c|c|c|}
\hline Number & $\begin{array}{l}\text { Type of } \\
\text { Campsites: } \\
\text { Factor A }\end{array}$ & $\begin{array}{l}\text { Number of } \\
\text { Campsites: } \\
\text { Factor B }\end{array}$ & $\begin{array}{c}\text { Distance } \\
\text { Away From } \\
\text { "Other Activities" } \\
\text { Factor C }\end{array}$ & $\begin{array}{l}\text { Average } \\
\text { Score } \\
\text { Values }\end{array}$ \\
\hline $\begin{array}{r}1 \\
2 \\
3 \\
4 \\
5 \\
6 \\
7 \\
8 \\
9 \\
10 \\
11 \\
12 \\
13 \\
14 \\
15 \\
16 \\
17 \\
18 \\
19 \\
20 \\
21 \\
22 \\
23 \\
24 \\
25 \\
26 \\
27\end{array}$ & $\begin{array}{l}\text { A1 } \\
A 1 \\
A 1 \\
A 1 \\
A 1 \\
A 1 \\
A 1 \\
\text { A1 } \\
A 1 \\
A 2 \\
A 2 \\
A 2 \\
A 2 \\
\text { A2 } \\
\text { A2 } \\
\text { A2 } \\
\text { A2 } \\
\text { A2 } \\
\text { A3 } \\
\text { A3 } \\
\text { A3 } \\
\text { A3 } \\
\text { A3 } \\
\text { A3 } \\
\text { A3 } \\
\text { A3 } \\
\text { A3 }\end{array}$ & $\begin{array}{l}\text { B1 } \\
\text { B1 } \\
\text { B1 } \\
\text { B2 } \\
\text { B2 } \\
\text { B2 } \\
\text { B3 } \\
\text { B3 } \\
\text { B3 } \\
\text { B1 } \\
\text { B1 } \\
\text { B1 } \\
\text { B1 } \\
\text { B2 } \\
\text { B2 } \\
\text { B3 } \\
\text { B3 } \\
\text { B3 } \\
\text { B1 } \\
\text { B1 } \\
\text { B1 } \\
\text { B2 } \\
\text { B2 } \\
\text { B2 } \\
\text { B3 } \\
\text { B3 } \\
\text { B3 }\end{array}$ & $\begin{array}{l}\text { C1 } \\
\text { C2 } \\
C 3 \\
C 1 \\
C 2 \\
C 3 \\
C 7 \\
C 2 \\
C 3 \\
C 7 \\
C 2 \\
C 3 \\
C 1 \\
C 2 \\
C 3 \\
C 1 \\
C 2 \\
C 3 \\
C 1 \\
C 2 \\
C 3 \\
C 7 \\
C 2 \\
C 3 \\
C 1 \\
C 2 \\
C 3\end{array}$ & $\begin{array}{l}77.245 \\
60.510 \\
50.102 \\
52.143 \\
42.041 \\
38.980 \\
42.653 \\
35.000 \\
29.898 \\
60.408 \\
53.898 \\
46.633 \\
46.082 \\
38.837 \\
32.551 \\
33.714 \\
28.694 \\
26.816 \\
53.388 \\
45.510 \\
38.571 \\
40.837 \\
33.571 \\
26.327 \\
27.980 \\
18.878 \\
16.633\end{array}$ \\
\hline
\end{tabular}

Notations:

$$
\begin{aligned}
& \text { A. }=\text { primitive campsites for } \$ 2.00 \text { per night, } \\
& \text { A.2 }=\text { unimproved campsites for } \$ 3.00 \text { per night, } \\
& \text { A3 }=\text { improved campsites for } \$ 4.00 \text { per night, } \\
& \text { B1 }=1-50 \text { campsites, } \\
& \text { B2 }=51-100 \text { campsites, } \\
& \text { B3 }=101-150 \text { campsites, } \\
& C 1=2-3 \text { miles, } \\
& C 2=1-2 \text { miles, } \\
& C 3=\text { less than one mile, }
\end{aligned}
$$


estimate of the subjective integration of the three site attributes (stimuli) by the subjects. The stimulus-integration process employed here follows a simple linear model of functional measurement theory and this model predicts a parallelism (Anderson, 1972 and 1974). In order to verify the conformity of these subjective score values to this parallelism principle, graphical and statistical tests of fit were carried out using these subjective scores. A successful test implies that the response measure is "theoretically" adequate, that is, the response corresponds to the interval scale (Anderson, 1974).

The graphical test of fit is a simple plot of the scores as described below. The statistical test of fit is based on the following relations:

The ordinary analysis of variance can be used for this purpose because there is a direct relation between Equations 4 and 5 and the linear mode 7 used in the analysis of variance. The graphical prediction of parallelism from Equation 6 is equivalent to a zero Row $x$ Column "interaction". With a factorial design, therefore, the averaging model implies that the observed Row $x$ Column interactions should be statistically nonsignificant. The three-way design of Equation 5 leads to three such twoway interactions, plus a three-way interaction, all of which should be nonsignificant. If any interaction is found significant, that infirms the averaging model. The same holds for any linear model even if each stimulus is allowed its own weight parameter (Anderson, 1972, p. 10).

\section{Graphical Tests}

Raw response scores were plotted as illustrated in Figure 6. In each group, one of the three factors was held constant and the average subjective scores (Table III) are on the y-axis. A visual inspection

${ }^{1}$ These equations $(4,5$ and 6$)$ are equivalent to Equations 1,5 and 2 respectively mentioned on page 129 (Appendix E). 

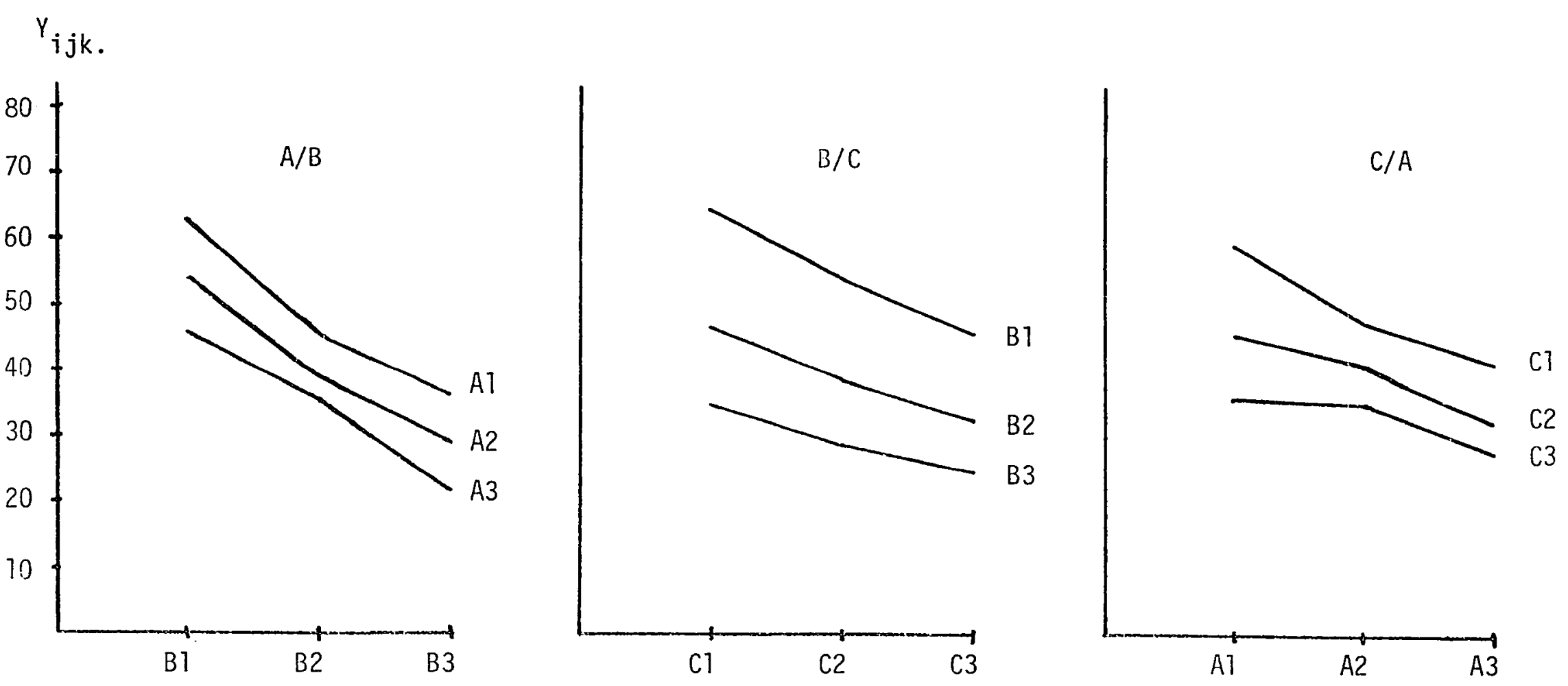

Notations:

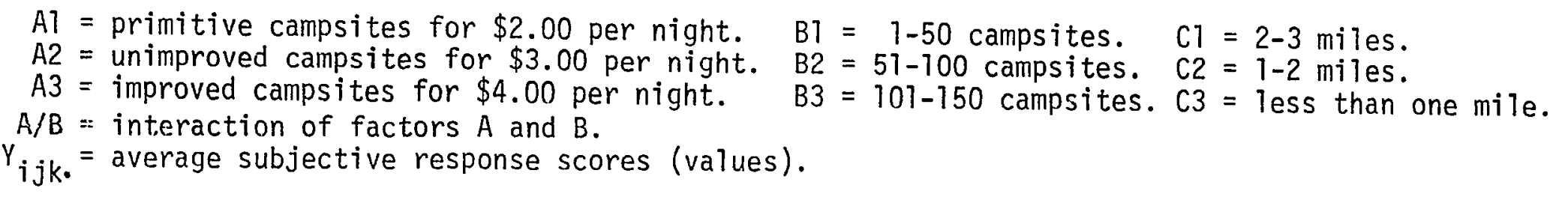

Figure 6. Graphs showing parallelism. 
of these figures shows that these responses conform to the linear model: parallelism is apparent.

\section{Statistical Tests}

These tests revolve around a three-way analysis of variance. The row-column interaction effects are the thrust of this analysis. A three-factor design was used. Each factor corresponds to one of the three campsite's attributes with three variations (levels).

$$
\text { Let } Y_{i j k e} \text { represent any of the subject's score }
$$

where:

$$
\begin{aligned}
& Y=\text { Subject's score (observed). } \\
& i=\text { First factor } A \text {, "wilderness", } i=1 \\
& j=\text { Second factor } B \text {, "crowdedness", } j=1 \\
& \begin{array}{l}
k=\text { Third factor } c \text {, "remoteness ... ", } \\
k=1, \ldots . ., c
\end{array} \\
& \mathrm{e}=\text { Number of subjects. } \\
& a=b=c=3 \text {, and } \\
& n=49 \\
& \text { and } Y_{i j k .}=\text { Average obtained from } 1 / e \sum_{e=1}^{\sum_{i j k e} \gamma_{i j e}}
\end{aligned}
$$

Then, a three-factor design model was tested. Table IV gives the relevant statistics. Also see Appendix $J$ for the analysis of variance model and related information. The $A B, B C, C A$ and $A B C$ interactions are not significant at 0.95 level of confidence; thus, the means of the observed-subject's scores are the scale values related to the stimulusintegration of the site's attributes. 
TABLE IV

THREE-WAY FACTORIAL DESIGN: ANALYSIS OF VARIANCE STATISTICS

\begin{tabular}{|l|c|c|c|c|c|}
\hline $\begin{array}{c}\text { Source of } \\
\text { Variation } \\
(1)\end{array}$ & $\begin{array}{c}\text { Sum of } \\
\text { Squares } \\
(2)\end{array}$ & $\begin{array}{c}d f \\
(3)\end{array}$ & $\begin{array}{c}\text { Mean } \\
\text { Squares } \\
(4)\end{array}$ & $\begin{array}{c}\text { Computed } \\
F \\
(5)\end{array}$ & $\begin{array}{c}\text { Tabled } \\
F \\
(6)\end{array}$ \\
\hline Due A & $43,841.574$ & 2 & $21,920.787$ & 74.20 & 3.00 \\
Due B & $140,778.666$ & 2 & $70,389.333$ & 238.27 & 3.00 \\
Due C & $45,221.022$ & 2 & $22,610.511$ & 76.54 & 3.00 \\
Due AB & $1,467.915$ & 4 & 365.479 & 1.24 & 2.37 \\
Due AC & $1,720.488$ & 4 & 430.122 & 1.46 & 2.37 \\
Due BC & $2,578.086$ & 4 & 644.522 & 2.18 & 2.37 \\
Due ABC & $382,855.246$ & 1296 & 295.413 & & 1.94 \\
Residual & 382,859 & & \\
Total & $618,457.802$ & 1322 & & & \\
\hline
\end{tabular}

$$
\begin{aligned}
F_{t}= & F[1-\alpha,(a-1)(b-1), a b c-1] \\
& \text { for } \alpha=0.05 \\
& a b c-1 \rightarrow \infty
\end{aligned}
$$

and $d f=$ Degree of freedom

The two tests, graphical and statistical, showed no interaction (Table IV and Figure 6). However, these raw subjective scores, reflecting recreational spatial preference still had to be integrated over the actual numerical values of the site's attributes which were considered. This was done by regressing these values (dependent variable) on the site's attributes (independent variabies) so as to obtain a predictive equation. As confirmed by the test above, a linear integration model was appropriate for these data; thus, a single linear model of stimulus-integration was used. Table $V$ shows the observed 
TABLE $V$

SCORE VALUES INTEGRATED ACROSS THE SITE ATTRIBUTES

\begin{tabular}{|c|c|c|c|c|c|}
\hline \multirow[b]{2}{*}{ Number } & \multirow[b]{2}{*}{ Factor A } & \multirow[b]{2}{*}{ Factor B } & \multirow[b]{2}{*}{ Factor C } & \multicolumn{2}{|c|}{$\begin{array}{l}\text { Site's Attribute } \\
\text { Score Values (SAV) }\end{array}$} \\
\hline & & & & $\begin{array}{l}\text { Observed } \\
\text { (Tab7e III) }\end{array}$ & $\begin{array}{l}\text { Predicted } \\
\text { (Equat. 17) }\end{array}$ \\
\hline $\begin{array}{l}1 \\
2 \\
3 \\
4 \\
5 \\
6 \\
7 \\
8 \\
9 \\
10 \\
11 \\
12 \\
13 \\
14 \\
15 \\
16 \\
17 \\
18 \\
19 \\
20 \\
21 \\
22 \\
23 \\
24 \\
25 \\
26 \\
27\end{array}$ & $\begin{array}{l}A 1=2.00 \\
A 1=2.00 \\
A 1=2.00 \\
A 1=2.00 \\
A 1=2.00 \\
A 1=2.00 \\
A 1=2.00 \\
A 1=2.00 \\
A 1=2.00 \\
A 2=3.00 \\
A 2=3.00 \\
A 2=3.00 \\
A 2=3.00 \\
A 2=3.00 \\
A 2=3.00 \\
A 2=3.00 \\
A 2=3.00 \\
A 2=3.00 \\
A 3=4.00 \\
A 3=4.00 \\
A 3=4.00 \\
A 3=4.00 \\
A 3=4.00 \\
A 3=4.00 \\
A 3=4.00 \\
A 3=4.00 \\
A 3=4.00\end{array}$ & $\begin{array}{l}\mathrm{B} 1=25 \\
\mathrm{~B} 1=25 \\
\mathrm{~B} 1=25 \\
\mathrm{~B} 2=75 \\
\mathrm{~B} 2=75 \\
\mathrm{~B} 2=75 \\
\mathrm{~B} 3=125 \\
\mathrm{~B} 3=125 \\
\mathrm{~B} 3=125 \\
\mathrm{~B} 1=25 \\
\mathrm{~B} 1=25 \\
\mathrm{~B} 1=25 \\
\mathrm{~B} 2=75 \\
\mathrm{~B} 2=75 \\
\mathrm{~B} 2=75 \\
\mathrm{~B} 3=125 \\
\mathrm{~B} 3=125 \\
\mathrm{~B} 3=125 \\
\mathrm{~B} 1=25 \\
\mathrm{~B} 1=25 \\
\mathrm{~B} 1=25 \\
\mathrm{~B} 2=75 \\
\mathrm{~B} 2=75 \\
\mathrm{~B} 2=75 \\
\mathrm{~B} 3=125 \\
\mathrm{~B} 3=125 \\
\mathrm{~B} 3=125\end{array}$ & 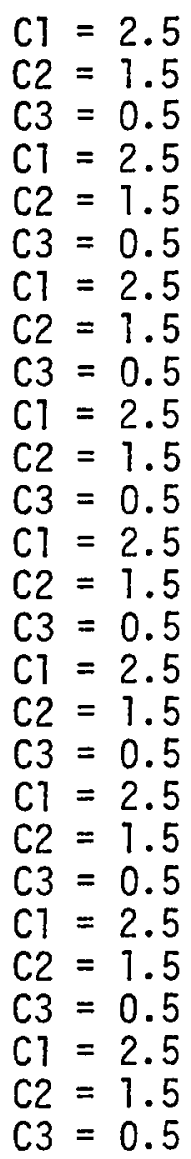 & $\begin{array}{l}77.245 \\
60.510 \\
50.102 \\
52.143 \\
42.041 \\
38.980 \\
42.653 \\
35.000 \\
29.898 \\
60.408 \\
53.898 \\
46.633 \\
46.082 \\
38.837 \\
32.551 \\
33.714 \\
28.694 \\
26.816 \\
53.388 \\
45.510 \\
38.571 \\
40.837 \\
33.571 \\
26.327 \\
27.980 \\
18.878 \\
16.633\end{array}$ & $\begin{array}{l}65.583 \\
58.582 \\
58.582 \\
53.417 \\
46.415 \\
46.415 \\
41.250 \\
34.249 \\
27.247 \\
59.312 \\
52.310 \\
45.309 \\
47.146 \\
40.144 \\
33.743 \\
34.979 \\
27.978 \\
20.976 \\
53.042 \\
46.040 \\
39.039 \\
40.875 \\
33.874 \\
26.872 \\
28.709 \\
21.707 \\
14.706\end{array}$ \\
\hline
\end{tabular}

Notations:

$A 1=$ primitive campsites for $\$ 2.00$ per night,

$A 2=$ unimproved campsites for $\$ 3.00$ per night,

$A 3=$ improved campsites for $\$ 4.00$ per night,

$B 1=1-50$ campsites; 25 campsites as midpoint value,

B2 = 51-100 campsites; 75 campsites as midpoint value,

B3 = 101-150 campsites; 125 campsites as midpoint value,

$\mathrm{Cl}=2-3$ miles; 2.5 miles as midpoint value,

$\mathrm{C2}=1-2$ miles; 1.5 miles as midpoint value,

$\mathrm{C} 3=$ less than one mile; 0.5 mile as midpoint value,

$n=49$. 
and predicted score values and the attributes. The following is the predictive equation, with $R^{2}$ of 0.93 :

$$
\begin{aligned}
& \text { SAV }=66.704-6.271 x_{1}-0.243 x_{2}+7.002 x_{3} \\
& \text { for SAV = Site's attribute score values. } \\
& x_{1}=\text { Cost of a campsite, factor A. } \\
& \begin{aligned}
X_{2}= & \begin{array}{l}
\text { Number of the campsites at a site, } \\
\text { factor } B .
\end{array}
\end{aligned} \\
& \begin{aligned}
X_{3}= & \text { Remoteness from "other activities", } \\
& \text { factor } C \text {. }
\end{aligned}
\end{aligned}
$$

Given a set of site attributes $\left(x_{1}\right.$ to $\left.x_{3}\right)$, a SAV can be obtained by using the above equation regardless of the location of the site. The predicted SAV, Table $V$, are invariant with respect to the zone size effects and are not site specific. Note that this model underestimates the extreme values at both ends. This reflects a general difficulty in estimating extreme cases (Anderson, 1972 and 1974).

\section{MIX OF ACTIVITY AND SITE ATTRIBUTE WEIGHTS}

Finally, the relative weights of activity $\operatorname{mix}(k)$ and site attributes (c) were derived from the survey information. All subjects were asked to note which of these two sets of information they characteristically consider first in selecting a campground. This followed from the earlier evidence of step-wise decision making.

The $k$ and $c$ were empirically derived from the subjects' responses to this question (Appendix G). Table VI contains the subjects' responses to this recreational travel decision process. 
TABLE VI

DERIVATION OF $k$ AND $c$ WEIGHTS FOR THE DESTINATION CHOICE FUNCTION

\begin{tabular}{|c|c|}
\hline $\begin{array}{c}\text { Elements of Decision Process } \\
\text { (Sequence) }\end{array}$ & Percent* \\
\hline 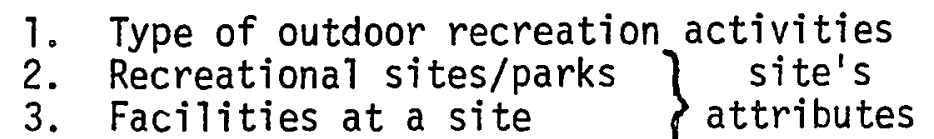 & $\begin{array}{l}52.414 \\
30.345 \\
17.241\end{array}$ \\
\hline
\end{tabular}

*Based on frequencies of responses.

The weight relative to the activity mix component of $A_{j}$ is:

$$
1.101=\frac{52.414}{47.586}=k
$$

The one relative to the site attribute component of $A_{j}$ is:

$$
1.000=c
$$

Both $k$ and $c$ are used as weights in the Equation 18.

$$
\text { VII. CALCULATED } A_{j} \text { SCORES FOR ACTUAL PARKS }
$$

Thus, al1 parameters for calculating $A_{j}$ have been derived from the survey data. It should be possible to estimate the site attractiveness of any park because the preference ratings refer to abstract stimuli rather than an actual group of parks, by calculating the MA and SA scores and combining them according to the formula below:

$$
A_{j}=(k)(M A V)+(c)(S A V)
$$


where:

$$
\begin{aligned}
& \begin{array}{l}
A_{j}=\quad \text { Weighted score for the } i^{\text {th }} \text { recreation area. } \\
\text { This is the proxy for the site's attractive- }
\end{array} \\
& \text { ness. } \\
& \text { MAV = Scale values derived from paired comparison } \\
& \text { (mix of activities). } \\
& \text { SAV = Subjective scores value from stimulus-inte- } \\
& \text { gration responses (site's attributes), ob- } \\
& \text { tained from Equation } 17 . \\
& k, c=\text { Weights (constants); } k \text { is for the activity } \\
& \text { mix preference, while } c \text { is about the perceived } \\
& \text { and integrated characteristics (attributes) of } \\
& \text { a site. }
\end{aligned}
$$

This was done for a selected group of 16 Oregon campground areas.

The scores are reported in Table VII; these sites and scores will be used in the calibration, validation, and sensitivity analysis steps of this research. 
TABLE VII

INDICES OF SITE ATTRACTIVENESS - $A_{j}$

\begin{tabular}{|c|c|c|c|c|}
\hline I.D. & Park Name & MAV & $\begin{array}{c}\text { SAV } \\
\text { Predicted }\end{array}$ & $A_{j}^{*}$ \\
\hline 1 & Bullards & 55.64 & 37.930 & 99.19 \\
\hline 2 & Champoeg & 45.78 & 45.309 & 95.71 \\
\hline 3 & Clyde Holliday & -42.74 & 52.310 & 5.25 \\
\hline 4 & Deschutes & -2.57 & 45.309 & 42.48 \\
\hline 5 & Emigrant Springs & 2.79 & 42.170 & 45.24 \\
\hline 6 & Farewell Bend & 31.23 & 36.090 & 70.47 \\
\hline 7 & Harris Beach & 45.78 & 42.170 & 92.57 \\
\hline 8 & Lapine & 45.78 & 50.090 & 100.49 \\
\hline 9 & Milo McIver & 45.78 & 45.309 & 95.71 \\
\hline 10 & Silver Falls & 45.78 & 52.310 & 102.71 \\
\hline 11 & Sunset Bay & 45.78 & 45.309 & 95.71 \\
\hline 12 & William Tugman & -2.57 & 20.976 & 18.15 \\
\hline 13 & Tuma 10 & 45.78 & 50.090 & 100.49 \\
\hline 14 & Umpqua Lighthouse & 2.79 & 49.180 & 52.25 \\
\hline 15 & Unity Lake & -2.57 & 45.309 & 42.48 \\
\hline 16 & Viento & 2.79 & 45.309 & 48.38 \\
\hline
\end{tabular}

${ }^{*} A_{j}=1.101$ (MAV) +1.000 (SAV)

where the SAV is from equation 17 (predicted SAV) and MAV is derived from equation 16. 
CHAPTER VI

MODEL CALIBRATION, VALIDATION, AND EXTENSION

I. INTRODUCTION

The process of developing a model requires at least two procedural steps: (1) the model theoretical structure is first postulated/ proposed; and (2) the structural relationship of the model is then calibrated. The purpose of calibrating the structural equation of the model is to estimate its parameters. In the preceding sections, structure and components were defined; this accomplishes the first of these two steps. The model structural relationship can be calibrated through any of the following curve/model fitting techniques.'

1. Linear regression--ordinary least squares.

2. "Simultaneous" least squares.

3. Non-linear regression.

4. Maximum likelihood principle.

The first of these techniques is less appropriate because the functional form of the model is non-linear. The second is inappropriate because simultaneous least squares implies multi-modal models; this one is to estimate only one mode travel demand, automobile travel. Maximum likelihood and non-linear regression are conceptually superior statistical procedures for calibrating a model such as the one in this study primarily because exponents are directly estimated (Watson, 1974; Robinson and Grecco, 1972; Quandt, 1970; Peers et a1., 1975).

${ }^{1}$ Quandt has suggested the Monte Carlo methods of multiple quandrature to verify this type of equation (Quandt, 1970). 
Linearizing the form results in less accurate parameter specification because of information distortion in logging and antiloging the scores and mathematical differences in the formulation of squared deviation between linear and non-linear methods. However, computer software for both the maximum likelihood and non-linear models were not available to this researcher nor are they likely to be accessible to most practitioners who might apply this model. Hence, a linearized form of the model was the structure calibrated here. It is restated as follows:

$$
\ln T_{i j}=\ln \alpha_{i}+\alpha_{2} \ln p_{i}+\alpha_{3} \ln A_{j}+\alpha_{4}\left(a_{i j}+K i_{i j}\right)
$$

where:

$$
\text { In }=\log \text { to the base } e \text {. }
$$

\section{PARAMETER ESTIMATION RESULTS}

The $A_{j}$ of Equation 8 is defined for the Portland (urbanized area) population. Logically, the model should be verified using the PortTand population $\left(P_{i}\right)$ and its derived $A_{j}$. In order to accomplish this, Portland was partitioned into 20 subareas, commonly called traffic analysis zones (Figure 2$)$. Travel time $\left(t_{i j}\right)$, population $\left(P_{i}\right)$, number of round trips $\left(T_{i j}\right)$, and costs $\left(a_{i j}\right)$ from these subareas to the destinations under consideration were derived from the various sources detailed earlier for the year 1975. Subsequently, $\left(a_{i j}+k t_{i j}\right)$ was calculated. The $A_{j}$ values were related to the enumerated sites. The $A_{j}$ values were computed according to the facilities available at the sample parks employing the parameters and functional relationship established earlier (see Equation 18, page 81). 
The estimated parameter values, and $R^{2}$ as well as the model estimated travel patterns $\left(T^{\prime}{ }_{i j}\right)$ and the observed ones $\left(T_{i j}\right)$ are contained in Table VIII. This $R^{2}$ is much higher than those obtained by Thompson (1967), Deacon et a1. (1973) and others. Moreover, this model reproduces the observed $T_{i j}$ quite well (see Table VIII, part $b)$. Since the independent variables are measured on different units (population, attractiveness index and generalized trave1 costs) standardized regression coefficients (beta weights) are included in Table VIII for the purpose of comparing the relative effect of each independent variable on the dependent variable directly. 1

\section{MODEL VALIDATION}

The validation process for this model was performed through the application of the model parameters, as calculated from the 1975 data, to estimate the 1973 travel patterns, known travel data. The object was to reproduce the 1973 Portland camping travel patterns, $T_{i j}$, in other than the calibration year. The actual 1973 travel patterns, $T_{i j}$, were compared with those, $T^{\prime}{ }_{i j}$, estimated by the model.

$$
\text { 1 Beta weights: } \quad B=\alpha_{y x}\left(\frac{s_{x}}{s_{y}}\right)
$$

where:

$$
\begin{array}{cl}
\alpha_{y x} & \text { is the regression coefficient. } \\
s_{x} & \text { is the standard deviation of } x . \\
s_{y} & \text { is the standard deviation of } y .
\end{array}
$$


TABLE VIII

PORTLAND AREA (1975) MODEL: PARAMETER ESTIMATES AND RECREATIONAL (CAMPING) TRAVEL PATTERNS

\begin{tabular}{|c|c|c|c|c|c|c|}
\hline a. & \multicolumn{6}{|c|}{ Parameter Estimates 1} \\
\hline & Parameters & $\alpha_{1}$ & $\alpha_{2}$ & $\alpha_{3}$ & $\alpha_{4}$ & \\
\hline & $\begin{array}{l}\text { 1. } \begin{array}{l}\text { Regression } \\
\text { Coefficients }\end{array}\end{array}$ & -2.851 & 1.120 & 0.532 & -0.001 & \multirow{2}{*}{$R^{2}=0.83$} \\
\hline \multicolumn{2}{|c|}{$\begin{array}{l}\text { 2. Beta } \\
\text { Weights }\end{array}$} & & 0.816 & 0.405 & -0.059 & \\
\hline \multicolumn{7}{|c|}{ b. Actual and Model Estimated $T_{i j}$} \\
\hline I.D. & \multicolumn{2}{|c|}{ Park Name } & \multicolumn{2}{|r|}{ Actual $T_{i j}$} & \multicolumn{2}{|c|}{$T_{B y}^{i}{ }^{i}{ }^{\prime}{ }_{T h e}^{\text {Estimated }}$} \\
\hline $\begin{array}{r}1 \\
2 \\
3 \\
4 \\
5 \\
6 \\
7 \\
8 \\
9 \\
10 \\
11 \\
12 \\
13 \\
14 \\
15 \\
16\end{array}$ & \multicolumn{2}{|c|}{$\begin{array}{l}\text { Bullards } \\
\text { Champoeg } \\
\text { Clyde Holliday } \\
\text { Deschutes } \\
\text { Emigrant Springs } \\
\text { Fareweil Bend } \\
\text { Harris Beach } \\
\text { Lapine } \\
\text { Milo McIver } \\
\text { Silver Falls } \\
\text { Sunset Bay } \\
\text { William Tugman } \\
\text { Tumalo } \\
\text { Umpqua Lighthouse } \\
\text { Unity Lake } \\
\text { Viento }\end{array}$} & \multicolumn{2}{|r|}{$\begin{array}{r}1,010 \\
800 \\
196 \\
868 \\
520 \\
618 \\
856 \\
1,152 \\
1,170 \\
988 \\
850 \\
468 \\
1,254 \\
402 \\
458 \\
468\end{array}$} & \multicolumn{2}{|c|}{$\begin{array}{l}878 \\
932 \\
180 \\
689 \\
550 \\
666 \\
822 \\
906 \\
937 \\
962 \\
864 \\
343 \\
912 \\
509 \\
507 \\
491\end{array}$} \\
\hline
\end{tabular}

1 These values are based on the Equation 19 rather than on the Equation 8. The value of $\alpha$ for the Equation 8 is $0.058\left(e^{-2.851}=\right.$ 0.058 ) and the values of $\alpha_{2}, \alpha_{3}$, and $\alpha_{4}$ for the same equation are as indicated. 
The 1973 Portland travel patterns were based on the 1973 Portland subarea's population $\left(P_{j}\right)$, income $(Y)$, travel times $\left(t_{i j}\right)$, travel cost per mile $(M)$, recreational travel expenditure rate $(R)$, and the 1975 values of the site's attractiveness, $A_{j}$. However, the fuel availability factor $(\gamma)$ for the 1973 year was not available. This was determined by varying the value of $\gamma$ until a high degree of association between actual and estimated 1973 Portland camping travel patterris resulted. The degree of association was measured through Pearson's coefficient of correlation $(r)$. The highest value of $r$ obtained was 0.95 and $r^{2}=0.90$. The resulting value of $\gamma$ was 17.8 percent. This value of $\gamma$ is within the generally accepted range (15-20\%) of "fuel shortage" as accumulated over that period (U.S. Department of Transportation, October 1975). Table IX shows the actual and model estimated 1973 Portland area travel patterns, and related statistics. The results of this test imply that this model is stable with respect to the 1973-1974 time period.

\section{STATEWIDE EXTENSION}

\section{Input Data and Estimated Parameters}

The model was then extended through $P_{i}$ to the other Oregon urban areas whose population was 10,000 or more in 1975 . The extension of the model implies that urban residents, as defined above, would view recreational sites for the purpose of camping in the same manner as do Portland residents. This assumes that they possess the same utility function with respect to the attractiveness of a site derived from the subjective judgment about the mixes of activities and site's attributes. Thus, the values of $A_{j}$ used for the Portland urbanized 
TABLE IX

COMPARISON OF THE ACTUAL AND MODEL ESTIMATED RECREATION TRAVEL PATTERNS FOR THE PORTLAND AREA (1973): MODEL VALIDATION

\begin{tabular}{|c|c|c|c|}
\hline I.D. & Park Name & $\begin{array}{c}\text { Actual } 1973 \\
\text { Travel Patterns } \\
T_{i j}\end{array}$ & $\begin{array}{c}\text { Model Estimated } \\
\text { Travel Patterns } \\
{ }^{T_{i j}}\end{array}$ \\
\hline 1 & Bullards & 808 & 842 \\
\hline 2 & Champoeg & 462 & 582 \\
\hline 3 & Clyde Holliday & $i 54$ & 215 \\
\hline 4 & Deschutes & 648 & 505 \\
\hline 5 & Emigrant Springs & 504 & 402 \\
\hline 6 & Fareweil Bend & 542 & 544 \\
\hline 7 & Harris Beach & 780 & 751 \\
\hline 8 & Lapine & 968 & 900 \\
\hline 9 & Milo McIver & 908 & 978 \\
\hline 10 & Silver Falls & 776 & 723 \\
\hline 11 & Sunset Bay & 740 & 830 \\
\hline 12 & William Tugman & 380 & 300 \\
\hline 13 & Tuma 10 & 1,086 & 900 \\
\hline 14 & Umpqua Lighthouse & 198 & 226 \\
\hline 15 & Unity Lake & 226 & 375 \\
\hline 16 & Viento & 304 & 392 \\
\hline & \rangle & 9,484 & 9,405 \\
\hline \multicolumn{2}{|c|}{ Average $\bar{T}_{i j}$ per campground: } & 592.75 & 587.81 \\
\hline & $\begin{array}{l}=0.95 \\
=0.90\end{array}$ & & \\
\hline
\end{tabular}


area were applied to the other urban areas in Oregon and the statewide modei parameters were estimated under these conditions. The $a_{i j}, t_{i j}$, and $P_{i}$ of cities shown in Figure 1 and subareas of Portland, Eugene/Springfield and Salem as shown in Figures 2 and 3 and the $A_{j}$ of the sites shown in Figure 4, formed the input to the linearized regression program--the same one used for the Portland subareas. In order to compute $a_{i j}$ and determine $t_{i j}$, the respective urban areas' centroids were located at the population centers and those for the recreation sites were located at the centers of the campgrounds.

Table $X$ gives the model parameters and related statistics. The model estimated travel patterns, $T^{\prime}{ }_{i j}$, and the observed patterns, $T_{i j}$, are also listed in Table $X$.

\section{Conclusions}

The statewide model estimates about 46 percent of $T_{i j}$, while for the Portland area, the model estimates up to 83 percent of 1975 travel patterns, $T_{i j}$. The severely underpredicted $T_{i j}$ values in the extended model occur in those campgrounds located near or along coastal regions. In terms of the explained variance, the high accuracy of the Portland model is a significant improvement over the standard direct demand models. Multiple $R^{2}$ values for these are commonly as low as 0.40 (Deacon et a1., 1973). Even the statewide model is acceptable. That the Portland model is more accurate is to be expected because the survey to derive $A_{j}$ was conducted there. Also, the most attractive sites according to the index are those which have many activities, coupled with sma11, inexpensive campsites isolated from the other campers. 
TABLE $X$

STATEWIDE EXTENSION OF $A_{j}$ : MODEL PARAMETERS AND TRAVEL PATTERNS BOTH ACTUAL AND MODEL ESTIMATED

\begin{tabular}{|c|c|c|c|c|c|c|}
\hline \multirow[t]{4}{*}{ a. } & \multicolumn{6}{|c|}{ Parameter Estimates 1} \\
\hline & Parameters & $\alpha_{1}$ & $\alpha_{2}$ & $\alpha_{3}$ & $\alpha_{4}$ & \\
\hline & $\begin{array}{l}\text { 1. Regression } \\
\text { Coefficients }\end{array}$ & -1.145 & 0.970 & 0.339 & -0.004 & \multirow{2}{*}{$R^{2}=0.46$} \\
\hline & $\begin{array}{l}\text { 2. } \text { Beta } \\
\text { Weights }\end{array}$ & & 0.585 & 0.213 & -0.181 & \\
\hline \multicolumn{7}{|c|}{ b. Actual and Model Estimated $T_{i j}$ (1975) } \\
\hline I.D. & \multicolumn{2}{|c|}{ Park Name } & & ual $T_{i j}$ & \multicolumn{2}{|c|}{$T_{B y^{j}}^{\prime}$ Estimated } \\
\hline $\begin{array}{r}1 \\
2 \\
3 \\
4 \\
5 \\
6 \\
7 \\
8 \\
9 \\
10 \\
11 \\
12 \\
13 \\
14 \\
15 \\
16\end{array}$ & \multicolumn{2}{|c|}{$\begin{array}{l}\text { Bullards } \\
\text { Champoeg } \\
\text { Clyde Holliday } \\
\text { Deschutes } \\
\text { Emigrant Springs } \\
\text { Farewel1 Bend } \\
\text { Harris Beach } \\
\text { Lapine } \\
\text { Milo McIver } \\
\text { Silver Falls } \\
\text { Sunset Bay } \\
\text { William Tugman } \\
\text { Tumalo } \\
\text { Umpqua Lighthouse } \\
\text { Unity Lake } \\
\text { Viento }\end{array}$} & \multicolumn{2}{|c|}{$\begin{array}{r}3,454 \\
1,186 \\
446 \\
1,148 \\
742 \\
998 \\
5,474 \\
1,950 \\
1,260 \\
1,722 \\
3,414 \\
1,862 \\
2,276 \\
1,484 \\
904 \\
664\end{array}$} & \multicolumn{2}{|c|}{$\begin{array}{r}1,441 \\
1,687 \\
493 \\
1,166 \\
832 \\
1,068 \\
1,260 \\
1,520 \\
1,652 \\
1,780 \\
1,429 \\
839 \\
1,572 \\
1,213 \\
934 \\
642\end{array}$} \\
\hline
\end{tabular}

1 These values are based on the Equation 19 rather than on the Equation 8. The value of $\alpha_{1}$ for the Equation 8 is 0.318 (e-1.145= 0.318 ) and the values of $\alpha_{2}, \alpha_{3}$, and $\alpha_{4}$ for the same equation are as indicated. 
This is a typical urbanist preference function (Catton, 1969), which may not be shared by residents outside of Portland.

The low results (underestimations) of the statewide model are not unusual. Thompson (1967) found a similar low estimation. Several reasons can be offered to account for this. These include effects of place of residence on outdoor recreational participation rates as reported by Hauser (1962), and Mueller and Gurin (1962) at the national level, and Burch and Wenger (1967) for Oregon; differences in the natural aspects of these sites, which were not included in the $A_{j}$ component; and effects of place of residence on attitudes toward the environment as reported by Catton (1969), where about 35 percent of recreationists did not show a wildernism attitude.

\section{SENSITIVITY AND POLICY IMPLICATIONS}

\section{Purposes}

The purpose of this section is to test the model through a sensitivity analysis and to evaluate its solution methods.' The calibrated model for the Portland area is used for this purpose. Changes in the model components resulted in a series of $T_{i j}$. These changes included the transportation level-of-service elements $\left(t_{i j}\right.$ and $\left.a_{i j}\right)$, and the components of the site attractiveness variable $A_{j}$.

${ }^{1}$ Sensitivity analysis attempts to ascertain the travel demand changes estimated by the model, given changes in policy-related variables (Peat et al., 1973). This analysis is consistent with the methodological criteria established earlier. 
The sensitivity analysis of $T_{i j}$ was carried out using the model component changes mentioned above. An analysis of the elasticity of travel demand $\left(T_{i j}\right)$ with respect to the same variables was also done. Due to computer time costs, the analysis was limited to selected variables and changes. Table XI shows the specific changes considered.

TABLE XI

MODEL APPLICATIONS: MODEL COMPONENT ALTERNATIVES (ASSUMPTIONS)

\begin{tabular}{|l|l|l|l|}
\hline \multicolumn{2}{|c|}{$A_{j}$} & \multicolumn{2}{|c|}{${ } \mathbf{i j}$} \\
\hline$M A$ & $S A$ & $M$ & $\gamma$ \\
\hline-- & -- & 20 & 10 \\
-- & -- & 20 & 20 \\
-- & -- & 30 & 10 \\
$-\Delta$ & -- & 30 & 20 \\
$+\Delta$ & -- & -- & -- \\
-- & $-\Delta$ & -- & -- \\
\hline
\end{tabular}

$+\Delta$ : Change in the appropriate component by increasing its value. $-\Delta$ : Change in the appropriate component by decreasing its value. The value of $M$ is in cents per mile. Alternative assumptions about $A_{j}$ components were limited to selected sites due to computer time costs.

\section{Assumptions Related to $a i j$}

Al1 the changes affecting the transportation level-of-service elements are made through $a_{i j}(\mathcal{M}$ and $\boldsymbol{\gamma}$ subcomponents). Possible changes about $t_{i j}$ such as speed change, peak/off-peak travel times and others were judged unsuitable for this study. The impact on $T_{i j}$ of the alternative assumptions considered is discussed below. 
An increase in $M$, cost per mile driven, from 20 to 30 cents results in a decrease of 7.73 percent in total $T_{i j}$, travel patterns. A high of 9.66 percent for the sites located over 150 miles from the Portland area was noted and parks within 100 miles show a loss of not more than 2.00 percent (a low of 1.11 percent). The same increase in $M$ and a reduction in $\gamma$, gas availability, of 10 percent and 20 percent cause a reduction of 9.34 percent and 11.28 percent in $T_{i j}$ respectively. However, a much larger variance in travel patterns was noted, with campgrounds located more than 150 miles away from the urban area losing between 12.69 and 16.29 percent of $T_{i j}$. High losses occur with respect to campgrounds located in the eastern part of the state (Farewell Bend, Emigrant Surings, Unity Lake, - . parks) followed by those along the coastal region (BuTlards Beach, William Tugman, Harris Beach, Umpqua Lighthouse, . . parks).

The central region campgrounds showed a moderate loss (Tumalo, Lapine, . . parks). The highest percent reduction in $T_{i j}$ in the Willamette Valley Region (Champoeg, Milo McIver, Viento, . . parks) was 2.71 (Silver Falls Park). Thus, the net effect of increase in $\mathcal{M}$ and decrease in $\gamma$, as noted above, is the shift in travel patterns and relatively small decline in total $\mathrm{T}_{i j}$ with the parks situated more than 100 miles from the urban areas showing the largest shift.

The gas availability factor, $\gamma$, was tested alone. Reductions of 10 percent and 20 percent in this factor achieved only 3.82 percent and 5.25 percent drops in the total $T_{i j}$ respectively. The resulting $T_{i j}$ followed to some extent those emanating from changes in 
the vehicle operating cost subcomponent as described above. However, this factor is not as sensitive as expected.

\section{Assumptions Related to $A_{j}$}

Both components of $A_{j}$ were modified for a few selected parks. For the mixes of activities (MA), the existing mix of activities was replaced by another, such as changing from $(a b)$ to $(a b c)$ or $(a b c)$ to (ab) (see Table II, page 70). In these alternative MA's, the site attribute component of $A_{j}$ was kept constant. In the case of site attributes (SA), only the characteristics of "proximity to other activities" was altered such as from $(A 2, B 1, C 2)$ to $(A 2, B 1, C 1)$ or $(A 2$, B1, C3) (see Table V, page 79) while the MA was kept constant. The changes in mixes of activities (MA) and site's attributes (SA) induce change in the corresponding values of MA and SA, MAS and SAS respectively. The gain, about 2.00 percent, in the total $T_{i j}$ derived from increasing the space between "other activities" is not as much as the loss $\left(7.38\right.$ percent) in the total $T_{i j}$ resulting from the reduction of that space, that is, isolation of campsites from other activities is a desirable attribute. However, the introduction of an additional activity generates up to 31.13 percent in total $T_{i j}$, while a reduction in the number of activities (by one) brings about a drop of 26.38 percent in $T_{i j}$ total. The changes in MA were introduced only for sites whose MA contains at least three different activities. 
Conclusions

The trip interchanges or travel patterns, $T_{i j}$ are more sensitive to the MA (mix of activities) changes than the SA (site attributes) changes. The effects of changes in site's attractiveness, $A_{j}$, on $T_{i j}$ are greater than those induced by changing the transportation cost, $a_{i j}$. However, line $a_{i j}$ affects the general travel patterns, $T_{i j}$

The increase in $\mathcal{M}$, cost per mile, and reduction in $\gamma$, fuel availability might not drastically affect camping activity $\left(T_{i j}\right)$ as a whole if changes are concurrently introduced to affect the $A_{j}$ through its components in the campgrounds 10cated within 100 miles of an urban area. These changes should be especially applied to the mix of activity (MA) component. These conclusions are to be expected since $A_{j}$ is a destination (site) component, thus a direct demand indicator while $a_{i j}$ is a spatial distribution subcomponent, thus a part of a derived demand component. 
CHAPTER VII

\section{CONCLUSIONS}

\section{MODEL RELATION TO THE METHODOLOGICAL CRITERIA}

The purpose of this study was to develop an extraurban recreational travel demand model structured around the framework established by the methodological criteria. It complies with these criteria: (7) being based on an internally consistent modeling approach. Its structure is direct and simple; (2) containing an aggregate travel choice component developed from preferences for alternative destinations for the purpose of camping; and (3) performing well for both the Portland area and statewide with results that are a significant improvement over the standard direct travel demand models as shown by their respective $R^{2}$ values.

A methodology for the derivation of the site's attractiveness was developed and applied. This method views the site's attractiveness, $A_{j}$, as a weighted sum of preferences for mixes of activities (MA) and the site's attributes (SA). These preferences were obtained through paired comparison and information integration techniques respectively. This methodology is not site specific and is independent of travel demand. Thus, the site's attractiveness, as developed here, is invariant with respect to the zone size and structure effects, and transferable to other circumstances. 
This site's attractiveness variable lends itself to the evaluation of the relative effects of the recreation services and facilities available at a site on the recreational travel demand. As stated above, this variable is developed from preferences for alternative site's attributes and activity mixes. These preferences show a wilderness attitude (Catton, 1969): primitive and unimproved campsites are preferred over the others. Mixes of activities not involving motor boating are preferred. Hence, concerns about the environment can be inferred. These considerations might not have been incorporated into the modeling process if the traditional approach was used in developing the attractiveness of a site. Thus, the proposed method for deriving $A_{j}$ may be considered as an improvement over the traditional method of estimating the attractiveness of a site.

The modeling approach is direct as mentioned earlier. The structure of the model includes the level-of-service variables, travel cost and time. The model is internally consistent, and changes in the properties of any of the above model components which might influence the interaction patterns can be easily estimated and evaluated as was demonstrated in Chapter VI (pages 92-96). As noted, this research confirms the previous findings on travel demand for outdoor recreation insofar as the spatial gradient, place of residence, destination and economic effects are concerned.

The Portland area test of the model performs quite well as indicated by the $R^{2}$ value $(0.83)$. This value is much higher than those obtained by Thompson (1967), Deacon et a1. (1973) and others. Even the statewide model compares favorabiy. In addition, this model is 
effective as shown by its ability to reproduce actual recreational travel patterns, to provide good model validation results, and to demonstrate the effects of alternative assumptions about the model components on the travel demand $\left(T_{i j}\right)$. With the explicit inclusion of level-of-service variables, the model is capable of estimating the effects of energy availability and pricing on recreation travel demand. The energy considerations may become one of the most significant recreation travel demand determinants and reduce in influence such prominent current factors as leisure time availability and attractiveness of recreation site.

Finally, the model can serve as either a long-range or a shortrange planning tool. The user should take into consideration the limitations under which this model was formulated. These limitations are discussed in the following section.

\section{MODEL LIMITATIONS}

The most serious problem encountered in the development of this model was the extension of $A_{j}$ to the statewide level. A low value of $\mathrm{R}^{2}$ was registered for the statewide model (see Table $X$, page 91). As previously stated, this is partiy due to the differences in preferences for alternative destinations as a function of place of residence. The derivation of $A_{j}$ was based on preferences for alternative recreational site's attributes and mixes of activities. Preferences are not necessarily stable with respect to time (Michaels, 1974), and vary according to place of residence as partly indicated by the differences in $R^{2}$ resulting from the Portland area and statewide models. 
This model does not adequately respond to the fuel availability alternatives (see pages 92-96) to the degree it does to site attractiveness changes. This is due partiy to the model calibration procedures used and mainly to the lack of information on the subject. This model is aggregated. As such, it cannot deal effectively with the issues related to the disaggregation of $T_{i j}$ by peak/off-peak and weekday-weekend trave1, alternative modes of travel, vehicle types and their respective fuel efficiency, and the like. However, these can be introduced into the model structure if the corresponding information is available.

The application of $A_{j}$ components to a specific site in oroder to derive its $M A$ and $S A$ of Equations 16 and 17 requires a good description of the site in terms of its mixes of activities and attributes. Discrepancies were noted among "park information" descriptions. These included certain objective measures of the site's attributes as well as the activity mixes. For instance, the "Oregon Parks" Map (1975 edition) indicates that 0swald West and Cascadia Parks have primitive campsites; however, this information was amended. In addition to this, precautions should be taken in determining the score and scale values of a site from the objective measures provided in the site description. This model may not provide acceptable estimates of $T_{i j}$ when it is applied to parks with hundreds of campsites. In this model, 150 campsites served as the upper level for the "crowdedness" factor. This model was not calibrated for parks with larger numbers of camping sites than this. Another set of $A_{j}$ may be necessary for this type of campground. 
The total area of certain parks includes both developed and undeveloped areas. This leads to uncertainty about choosing the appropriate levels of the "proximity to other activities" factor. Finally, better results were obtained when generalized cost is calculated using "actual" distances and minimum path travel times. It is recognized that trips do not always follow a minimum path especially for recreational travel. However, the shortest distance on highways is still better than straight line distance, especially if both differ.

\section{RECOMMENDATIONS}

The development of this model involved the preparation of a direct travel demand model which would include user choice behavior as it is related to alternative destinations for the purpose of camping. These objectives have been achieved (Chapters IV and V). However, there is need for further research in this area.

\section{Methodology for $A_{j}$ Derivation}

The process of acquiring the needed information from the potential and actual campground users to develop $A_{j}$ is quite cumbersome, repetitive and lengtiny from the respondents' point of view. In fact, with only four activities, one hundred and five pairs must be formed and evaluated. Three site attributes needing to be integrated in $3^{3}$ factorial-design leads to 27 combinations in addition to the nine end anchors which must be evaluated and scored. This constitutes a drawback to this approach. However, it is a design problem rather than a methodological deficiency. 
A series of design related suggestions are presented in the following paragraphs aimed at: (1) reducing the length of questionnaires and their repetitiveness aspects without the loss of the necessary information to develop $A_{j}$; (2) extending the concept of the $A_{j}$ to other recreational activities; and ( 3 ) expanding the $A_{j}$ in terms of its components, compared to the two-component variable used in this study. In the two-component approach, $A_{j}$ is a resultant of activity mixes and site's attributes integration score values as stated in this research. This two-component approach can be extended as described below.

\section{For Paired Comparison}

A set of basic activities, referred to as activity set base (ASB), related to camping is first established. Possibly elements of the set may be picnicking, outdoor games, fishing, etc. This set may be formed from a list of the "most participated in activities" while camping. It is possible that this set may contain onily one activity. However, it is not an empty set, ASB $\neq\{\emptyset\}$. This set may a7so be formed from an independent study such as a rank order of activities in terms of preference rather than importance of activities. The set should aiso be differentiated by regions if the state encompasses diverse geographic features such as the coast, mountain, lake, valley, desert, etc. Using this set as a given, activity mixes/ combinations can be formed with selected additional activities whose scale values are to be derived through paired comparisoris. These additional activities should not exceed three in number since three activities will result in only 21 pairs (see page $6 \overline{8}$ ). Each of the 
combinations will contain the activity set base as a part of the activity mixes. For instance:

Let (XYZ) represent the ASB.

Then $(X Y Z, a),(X Y Z, b),(X Y Z, c), \ldots,(X Y Z, a b c)$ activity mixes can be obtained.

where:

$$
\begin{aligned}
& X= \text { Picnicking; } Y \text { and } Z \text { for other elements of } \\
& \text { the ASB. }
\end{aligned}
$$

and

$$
\begin{aligned}
& a=\text { Fishing. } \\
& b=\text { Motor boating. } \\
& c=\text { Hiking or other activities. }
\end{aligned}
$$

A set of scale values can then be derived for the camping activity as outlined on pages 68-70. This process can easity be extended to day users' recreational activities such as picnicking, fishing, boating, swimming, hiking, horseback riding, playing games, field sports,

-. . This procedure may not be suitable for other day users' activities such as golfing, tennis, pleasure driving, ... and the like.

\section{For Information Integration}

This technique is best used under laboratory conditions. ${ }^{1}$ It can, however, be adopted for self-administration if appropriate modifications/precautions are made in regard to the factorial design and procedures used to administer the questions. As in the case of paired

This limitation (controlled environment) is due mainly to the time duration involved in filling in the questionnaire. 
comparison, the objective is to reduce the number of questions (combinations) submitted to the subjects for subjective judgment through functional measurement. However, this technique requires that the stimuli under investigation be perceived on an interval and continuous scale. A number of possible designs exist to accomplish this. The following is presented as one of the designs.

Let $L^{F}$ represent a factorial design notation where:

$$
\begin{aligned}
& \mathrm{F}= \begin{array}{l}
\text { Factors, attributes of the site to be } \\
\text { integrated. }
\end{array} \\
& \mathrm{L}= \text { Levels, contiruous objective measures } \\
& \text { related to } \mathrm{F} .
\end{aligned}
$$

Then, any factorial design for which $L^{F}<27$ should be sought as long as it provides enough information to derive $A_{j}$ and eases the task of the subject. $2^{3}, 3^{2}, 4^{2}$. . may be considered as element of $L^{F}$ set, for $L^{F}<27$.

The $3^{2}$ or $4^{2}$ factorial design may be recommended. This design can then be differentiated by a third facior $(F)$ such as socio-economic or demographic stratifications of the respondents (subjects). A fourth factor can be implicitly included. This could be accomplished by stating that the combinations to be evaluated are differentiated by geographic areas such as the coastal, mountain or plain. This would also allow the inclusion of natural feature stratifications insofar as they vary within a geographic region or area. In such design, the respondent from a given socio-economic or demographic background is requested to score only a limited number of combinations or 
a) ternatives (each set would contain only $9=3^{2}$ or $16=4^{2}$ combinations). The resulting scores would be based on only two factors with three or four levels $\left(3^{2}\right.$ or $\left.4^{2}\right)$. However, the scores would be differentiated by socio-economic or demographic factor of the similar number of levels as the factorial design adopted. They would also address a particular geographic region or natural feature.

Expansion of $A_{j}$ Components

Recall that $A_{j}$ is a sum of two components, activity mixes and site's attributes. Both of these address, at varying degree, the cultural aspects of the sites, man-made facilities or man-created potential. The natural aesthetic aspects of the sites are not included in the $A_{j}$ as derived. These can be implicitly included through the information integration as noted above or by using the concept of set base referred to earlier (page 102). This base deals with aesthetic valuation of the sites and might be based on geographic features such as riverfalls, desert, gorge, forest area, mountain, . . . With this base factor and additional factors with appropriate levels, a $3^{2}$ design can be established, and a third factor is added as above. The subjective scores can then be computed after the scores have been tested for the parallelism characteristics of the linear model of information integration. In this approach, preferential scores relative to these geographic features would be needed as weights or dummy variables in the regression analys is in order to relate the scores obtained from the information integration process. 
With the exceptions mentioned on page 103, these procedures can be applied to the day user activities. The thrust of the design relies on the selection of the elements of the ASB and the base factor for the paired comparison and the information-integration respectively. ${ }^{1}$ Again, both of them should be based on preference rather than on existing services (facilities). Once established, then the process used to derive $A_{j}$ for camping can be applied to this group (day users).

\section{Further Comments}

As proposed, the model is aggregated as it does not differentiate the estimated travel demand by age, income, occupation, time of the year and mode of travel other than autos. The travel pattern estimates are not diversified by weekend or weekday time periods. The $A_{j}$ reflects an aggregate behavior of auto using campers on a yearly basis. The model cannot deal effectively with peak load on the transportation system, provide direct information on the characteristics of the activity system of the users, or be considered as a resource for planning or policy analysis for urban areas other than the one used to calibrate the model. This is mainly due to two reasons: (1) the $T_{i j}$ used to calibrate the model are yearly aggregate travel patterns; and (2) the $A_{j}$ is an aggregate variable, derived for the Portland area only. The former is a purely mechanical problem and can be solved with minor changes in the recording system of travel information. The

The ASB elements ought to refer to activities which can be engaged in at any recreational area in the park system under consideration. 
latter is fundamental to the behavorial travel demand estimation procedures, and evolves partly around the derivation of $A_{j}$. The above suggested design modifications might be used to gather appropriate information for the development of $A_{j}$. Several questions need to be answered, among them are the theoretical basis for aggregating the disaggregate $A_{j}$ even within age or income groups or occupation categories, the extension of $A_{j}$ derivation procedures to other recreational activities, and the expansion of $A_{j}$ to include additional components. The type and amount of attitudinal variables that an individual may consider in making recreational travel decisions involving activity and spatial preferences may vary according to individual characteristics. However, an expansion of $A_{j}$ components (assuming that the attitudinal variables will address $A_{j}$ ) as to exceed the boundaries of the inequalities estabiished on page 104 regarding the $L^{F}$ factorial design may result in fruitless efforts. The number of levels ( $L$ in $L^{F}$ factorial) that the average individual can differentiate is Timited (Hensher, 1974). 


\section{REFERENCES CITED}

Anderson, N.H. Information Integration Theory, a brief survey. Technical Report 24, Center for Human Information Processing, 1972.

"Algebraic Models in Perception." In Handbook of Perception, Volume II. Psychophysical Judgment and Measurements. Edited by E.C. Carterette and M.P., Friedman. Academic Press, 1974, pp. 215-298.

Beckmann, M.J. and Golob, T.F. "A Critique of Entropy and Gravity In Travel Forecasting." Theory of Traffic Flow and Transportation. Edited by G.F. Newe77. American ETsevier, 7972 .

Berg, W.D.; Bittner, W.L.; Koushki, P.A.; and Krueger, C.L. Upper Great Lakes Regional Recreation Planning Study Part 3: Transportation. Prepared for the Upper Great Lakes Regiona] Commission. University of Wisconsin - Madison, 1974.

"Development of a Regional Recreation Travel Simulation Model." Presented at the 54th Annual Meeting of the Transportation Research Board, January 1975.

Blackburn, A.J. "A Non-Linear Model of the Demand for Travel." In The Demand for Travel: Theory and Measurement. Edited by Richard E. Quandt. D.C. Heath and Company, 1970, pp. 163-179.

Brand, D. "Travel Demand Forecasting: Some Foundations and a Review." In Urban Travel Demand Forecasting. Proceedings of a conference. Highway Research Board, Special Report 143, 1973.

"Separable Versus Simultaneous Trave1-Choice Behavior." In Behavioral Demand Modeling and Valuation of Travel Time. Proceedings of a conference. Transportation Research Board, Special Report 149, 1974, pr. $\overline{18 \bar{i}-206 .}$

Burch, W.R., Jr. and Wenger, W.D., Jr. The Social Characteristics of Participants in Three Styles of Family Camping. Pacific Northwest Forest and Range Experiment Station. U.S. Department of Agriculture, 1967. 
Burnett, K.P. "Disaggregate Behavioral Models of Travel Decisions Other Than Mode Choice: A Review and Contribution to Spatial Choice Theory." In Behavioral Demand Modeling and Valuation of Travel Time. Proceedings of a conference. Transportation Research Board, Special Report 149, 1974, pp. 207-222.

"The Dimensions of Alternatives in Spatial Choice Processes." Geographical Analysis, Volume 5, 1973, pp. 181-204.

Catton, W.R., Jr. "Influence of Early Environment on Recreational Behavior." American Association for the Advancement of Science Meeting. Boston, Massachusetts, December 1969.

Clawson, M. and Knetsch, J.L. Economics of Outdoor Recreation. John Hopkins Press, 1971.

Crevo, C.C. "Characteristics of Summer Weekend Recreational Travel." Highway Research Board, No. 41, 1963, pp. 51-60.

Deacon, J.A.; Pigman, J.G.; Kaltenbach, K.D.; and Deen, R.C. "Models of Outdoor Recreational Travel." Highway Research Board, No. 472, 1973.

Demetsky, M.J. "Attitudinal Data." In Behavioral Demand Modeling and Valuation of Travel Time. Proceedings of a conference. Transportation Research Board, Special Report 149, 1974, pp. 27-24.

Dobson, R. "On the Assessment of Attitudinai and Behavioral Responses to Transportation System Characteristics." In Design of Procedures to Evaluate Traveler Responses to Changes in Transportation System Supply, Conference Summary and White Paper. Proceedings of a conference. Federal Highway Administration, Urban Planning Division, September 1974.

Ellis, J.B. and Van Doren, C.S. "A Comparative Evaluation of Gravity and System Theory Models for Statewide Recreation Traffic Flows." Journal of Regional Science, Volume 6 , No. 2 , 1966.

Fisk, C. and Brown, G.R. "The Role of Model Parameters in the Trip Distribution Models." Transportation Research, Volume 9, JuTy, 1975, pp. 143-148.

Freeman, L.C. Elementary Applied Statistics: For Siudents in Behavioral Science. John Wiley and Sons, Inc., 1965. 
Golob, T.F. and Dobson, R. "Assessment of Preferences and Perceptions Toward Attributes of Transport Alternatives." In Behavioral Demand Modeling and Valuation of Travel Time. Proceedings of a conference. Transportation Research Board, Special Report 149, 1974, pp. 58-81.

Haney, D.G., and Peat, Marwick, Mitchell and Company. "Consistency in Transportation Demand and Evaluation Models." Highway Research Record, No. 392, 1972, pp. 13-25.

Hartgen, D.T. and Wachs, M. "Disaggregate Travel Demand Models for Special Context Planning: A Dissenting View." In Behavioral Demand Modeling and Valuation of Travel Time. Proceedings of a conference. Transportation Research Board, Special Report 149, 1974, pp. 116-126.

Hauser, P.M. "Demographic and Ecological Changes as Factors in Outdoor Recreation." In Trends in American Living and Outdoor Recreation. Outdoor Recreation Resources Review Commission, Study Report 22, 1962, pp. 27-59.

Heanue, K.E. and Pyers, C.E. "A Comparative Evaluation of Trip Distribution Procedures." Highway Research Record 114, 1966, pp. 20-37.

Hensher, D.A. "Problem of Aggregation in Disaggregate Behavioral Travel Choice Models With Emphasis on Data Requirements." In Behavioral Demand Modeling and Valuation of Travel Time. Proceedings of a conference. Transportation Research Board, Special Report 149, 1974, pp. 85-100.

Horton, F.E., and Reynolds, D.R. "Action Space Formation: A Behavioral Approach to Predicting Urban Travel Behavior." Highway Research Record 322, 1970, pp. 136-148.

Lancaster, K.J. "A New Approach to Consumer Theory." Journal of Political Economics, Volume 74, April 1966.

Levine, R.L.; Boling, R.H., Jr.; and Higgs, G.K. "Bundle Theory and Its Application to Recreation Choice: A Geographic Model." Man-Environment Systems, Volume 5, No. 4, July 1975.

Lime, D.W. Factors Influencing Campground Use in the Superior National Forest of Minnesota. North Central Forest Experiment Station. Forest Service, U. S. Department of Agriculture, 1971. 
"Behavioral Research in Outdoor Recreation Management: An Example of How Visitors Select Campgrounds." In Environment and The Social Sciences: Perspectives and Applications. Edited by J.F. Wohlwill and D.H. Carson. American Psychological Association, Inc., 1972, pp. 198-206.

Lisco, T.E. "Common Economics of Travel Time Value." In Behavioral Demand Modeling and Valuation of Travel Time. Proceedings of a conference. Transportation Research Board, Special Report 149, 1974, pp. 103-175.

Louviere, J.J. and Norman, K.L. "Integration of Attributes in Bus Transportation: Two Modeling Approaches." Journal of Applied Psychology, Volume 59, \#6, 1974, pp. 753-758.

Manheim, M.L. "Practical Implications of Some Fundamental Properties of Travel Demand Models." Highway Research Board, No. 422, 1973.

Marans, R.W. "Outdoor Recreation Behavior in Residential Environments." In Environment and The Social Sciences: Perspectives and Applications. Edited by J.F. WohTwill and D.H. Carson. American Psychological Association, Inc., 1972, pp. 217-232.

Matthias, J.S. and Grecco, W.L. "Simplified Procedure for Estimating Recreational Travel to Multi-purpose Reservoirs." Highway Research Record, No. 250, 1968.

Michaels, R.M. "Behavioral Measurement: An Approach to Predicting Transport Demand." In Behavioral Demand Modeling and Valuation of Travel Time. Proceedings of a conference. Transportation Research Board, Special Report 149, 1974, pp. 57-57.

Midwest Research Institute. Development of Models for Predicting Weekend Recreational Traffic: Quarterly Progress Report. Prepared for National Cooperative Highway Research Program on Project 7-9, Apri 1973.

Mueller, E. and Gurin, G. "Participation in Outdoor Recreation: Factors Affecting Demand Among American Adults." Outdoor Recreation Resources Review Commission, Study Report 20, 1962. 
Nakkash, T.Z. and Grecco, W.L., Joint Highway Research Project. "Activity-Accessibility Models of Trip Generation." Highway Research Record 392, 1972, pp. 98-110.

Outdoor Recreation Resources Review Commission (ORRRC). National Recreation Survey, Study Report 19, 1962.

Peat, Marwick, Mitchel1 and Company. A Review of Operational Urban Transportation Models. Final report submitted to FHWA, Apri1 1973.

Peers, J.B.; Bevilacqua, M.; Alan M. Voorhees and Associates, Inc. "Structural Travel Demand Models: An Intercity Application." Presented at 54th Annual Meeting of the Transportation Research Board, January 1975.

Quaridt, R.E. "The Demand for Transportation: Concepts and Methods." In Advanced Urban Transportation Systems. Edited by Mary Anne Williamson. Carnagie-Mel7or University, 1970.

"Introduction to the Analysis of Travel Demand." In The Demand for Travel: Theory and Measurement. Edited by R.E. Quandt. Heath Lexington Books, 1970.

Robinson, C.C. "Highway Capacity." In Transportation and Traffic Engineering Handbook. Edited by J.E. Baerwalk. Prentice-Ha71, Inc., 1976.

Robinson, D.C. and Grecco, W.L. "Stability of Recreation Demand Mode1." Highway Research Record, No. 401, 1972.

Roberts, P.0. "Demand Forecasting for Long-Range and Contemporary Options." In Urban Travel Demand Forecasting. Proceedings of a conference. Highway Research Board, Special Report $143,1973$.

Ruiter, E.R. "Analytical Structures." In Urban Travel Demand Forecasting. Proceedings of a conference. Highway Research Board, Special Report 143, 1973.

Rushton, G. "The Scaling of Location Preferences." In Behavioral Problems in Geography. Edited by K.R. Cox and R.G. Golledge. Department of Geography, Northwestern University, Evanston, I11inois, 1969, pp. 199-237.

"Behavioral Correlates of Urban Spatial Structure." Economic Geography, Volume 47, 1971, pp. 49-58. 
Schulmann, L.L. Traffic Generation and Distribution of Weekend Recreation Trips. Lafayette, Indiana: Purdue University Joint Highway Research Project. June 1964.

Thompson, B. "Recreational Travel: A Review and Pilot Study." Traffic Quarterly, October 1967.

Torgerson, W.S. Theory and Methods of Scaling. John Wiley 1958.

Ungar, A. "Traffic Attraction of Rural Outdoor Recreational Areas." National Cooperative Highway Research Program, Report 44, 1967.

U.S. Department of Transportation, Federal Highway Administration. Urban Transportation Planning, General Information and Introduction to System 360. March 1972.

"Cost of Operating an Automobile." May 1975.

"Highway and Petroleum Problem -- 4 Reports." October 2, 1975.

Van Doren, C.S. "A Recreational Travel Model for Predicting Campers at Michigan State Parks." Unpub7ished Ph.D. thesis, Department of Geography, Michigan State University, 1965.

Volk, D.J. "Factors Affecting Recreational Use of National Parks." Paper presented at the Annual Convention of the Association of American Geographers, Columbus, Ohio, 1965.

Voorhees, A.M. and Associates. Statewide Travel Forecasting Procedures, Including Activity Allocation and Weekend Travel; Phase II. Prepared for the U.S. Department of Transportation. Quarterly Report 1, October 1973.

Watson, P.L. The Value of Time, Behavioral Models of Modal Choice. Lexington Books, 1974.

Wicker, A. "Attitudes Versus Actions: The Relationship of Verbal and Overt Behavioral Responses to Attitude Objects." Social Issues, XXV, 1969, pp. 41-78.

Whitaker, R.W. and West, K.E. "The Intervening Opportunities Model: A Theoretical Consideration." Highway Research Record 250, 1968, pp. 1-7.

Wi1son, G.A. "Some New Forms of Spatial Interaction Mode1: A Review." Transportation Research, Volume 9, 1975, pp. 167-179.

"Entropy in Urban and Regional Modelling." Pion, London, 1970. 
"Travel Demand Forecasting: Achievements and Problems." In Urban Travel Demand Forecasting. Proceedings of a conference. Highway Research Board, Special Report 143, 1973.

Zahari, Y. Traveltime Budgets and Mobility in Urban Areas. Prepared for Federal Highway Administration. U.S. Department of Transportation, May 1974. 


\section{APPENDIX A \\ OREGON STATE PARKS: CAMPGROUND USAGE}

The table below shows the attendance at Oregon State campgrounds. These are camper nights, that is, the number of nights spent at these campgrounds by individuals or groups of individuals.

TABLE XII

OREGON STATE CAMPGROUND ATTENDANCE

\begin{tabular}{|l|c|}
\hline Fiscal Year & $\begin{array}{c}\text { Attendance at Oregon State } \\
\text { Campgrounds - Camper Nights }\end{array}$ \\
\hline $1968 / 69$ & $1,362,918$ \\
$1969 / 70$ & $1,458,607$ \\
$1970 / 71$ & $1,578,173$ \\
$1971 / 72$ & $1,803,089$ \\
$1972 / 73$ & $1,770,014$ \\
$1973 / 74$ & $1,541,587$ \\
$1974 / 75$ & $1,616,645$ \\
$1975 / 76$ & $1,705,788$ \\
\hline
\end{tabular}




\section{APPENDIX B}

THEORETICAL DEVELOPMENT OF THE TRAVEL DEMAND

Theoretical basis of consumer demand theory can be applied to travel demand. Attempts in that direction are reflected in the works of Quandt (1970), BTackburn (1970), Manheim (1973) and others. One such attempt is illustrated by the work of Ruiter (1973, pp. 187-189):

As stated by Lancaster (8) [1966], the following assumptions, each of which differs from the classical theory, are the essence of his approach:

1. The good, per se, does not give utility to the consumer; it possesses characteristics, and these characteristics give rise to utility.

2. In genera7, a good will possess more than one characteristics, and many characteristics will be shared by more than one good.

3. Goods in combination may possess characteristics different than those pertaining to the goods separately.

When the nature of transportation as a derive demand with many "prices" is considered, the relevance of Lancaster's approach to travel demand becomes evident. Transportation is a good with a number of characteristics that give rise to disutility, but is nevertheless consumed in combination with other goods because it makes possible the consumption of those goods. The other goods have 0 utility until they can be reached; then they provide utility that exceeds the disutility of transportation.

Without going any deeper into Lancaster's approach than the 3 assumptions quoted above, I shall provide a theoretical basis for expanding the single-valued price of classical economics to a vector of characteristics--the level-of-service variables--and for including measures of the activity system.

Utility functions now state the level of utility associated with the purchase of the quantities $z_{j}$ of a number of characteristics.

$$
u\left(z_{1}, z_{2}, \ldots \cdot z_{n}\right)
$$


These characteristics are obtained by engaging in a number of activities, $j$, each at level $W_{j}$. The relation between the vector of characteristic quantities, $Z$, and the vector of activity levels, $W$, is

$$
Z=B W
$$

where $B$ is a matrix of elements $b_{i j}$, each of which is the amount of characteristic $i$ provided per unit of activity $j$.

The amount of each good, $k$, consumed is $Q_{k}$, which depends on the consumption of goods in each activity, as represented by the following relation between the vector of goods consumed, $Q$, and $W$ :

$$
Q=A W
$$

where $A$ is a matrix of elements $a_{k j}$, each of which is the amount of good $k$ consumed per unit of activity $j$.

As in the classical theory, a budget constraint exists. In matrix notation,

$$
P Q \leqslant Y
$$

If $U$ could be maximized subject to the constraints shown in Eqs. 29, 30 and 33, the following relations would be expected:

$$
Q_{k}^{0}=D_{k}(P, Y, W, A, B)
$$

Al though Lancaster provides no general solution in terms of forms of the demand function $D_{k}(\cdot)$, he does discuss a number of implications of his approach. As an example, Eq. 33 provides a theoretical base for including measures of each of the following in demand functions in general and in travel demand functions in particular:

$$
\begin{aligned}
& \mathrm{P}=\text { prices of goods, } \\
& Y=\text { income level of the consumer, } \\
& W=\text { activity levels of the consumer, } \\
& A=\text { consumption of goods per unit of } \\
& \text { activity, and } \\
& B=\text { provision of characteristics per } \\
& \text { unit of activity. }
\end{aligned}
$$

A second implication occurs when a new good, such as a new mode of transportation, is considered. In the classical theory, this situation requires the reformulation of 
the utility function, $U$, in an additional dimension before estimates can be made of the effects of this new good on the former equilibrium state. Before the new good is available, there is no way to estimate the changes to the utility function. Because in Lancaster's approach the utility function is dimensioned by characteristics rather than goods, it remains unchanged when new goods are added. To revise the demand functions, therefore, if no new activities are expected, requires only adding to the dimensions of $Q, A$, and $P$. Because $Q$ and $P$ are variables, only a new row of coefficients of A must be determined, based on the amount of the new good that is consumed in each of the activities. This is a much more straightforward task than formulating a new utility function based on consumers' responses to a situation that does not yet exist.

In many cases, a new good may result in new activities. This can also be represented by expanding the dimensions of $A, B$, and $W$. New columns must be added to $A$ and $B$ to represent the consumption of goods and production of characteristics of these new activities. This also can be done much easier than adding a dimension to the utility function.

In summary the Lancaster's approach provides a number of bases for travel demand forecasting that are not provided by the classical theory. This added power has been recognized by a number of travel demand model developers. Others have gone beyond classical theory in ways that can only be supported by Lancaster's approach. His approach, therefore, can probably be profitably explored further by demand model developers. 
APPENDIX C

TRIP DISTRIBUTION MODELS

This appendix deals with three models that are generally used to distribute trips. These are: gravity, intervening opportunities and systems theory models. A discussion of each is provided below.

\section{Gravity Model}

Theoretically, the gravity model

.. is based upon the hypothesis that the trips produced at an origin and attracted to a destination are directly proportional to the total trip production at the origin, the total trip attraction at the destination, a calibrating term, and possibly a socio-economic adjustment factor. This relationship may be expressed as follows:

$$
T_{i j} \propto P_{i} A_{j} F_{i j} K_{i j}
$$

where:

$$
\begin{aligned}
& T_{i j}=\begin{array}{l}
\text { trips produced at } i \text { and attracted at } \\
j-\text {-trip interchanges, }
\end{array} \\
& P_{i}=\text { total trip production at } i, \\
& A_{j}=\text { total trip attraction at } j, \\
& F_{i j}=\text { calibration term for interchange } i j, \\
& K_{i j}=\begin{array}{l}
\text { socio-economic adjustment factor for } \\
\text { interchange } i j,
\end{array}
\end{aligned}
$$

and

$$
\begin{aligned}
i & =\text { an origin zone number, } i=1,2, \ldots, \\
n, & \text { number of zones. }
\end{aligned}
$$

(U.S. Department of Transportation, Federal Highway Administration, March, 1972, pp. IV-17 - IV-23). 
Equation 1 is generally expressed as:

$$
T_{i j}=P_{i} \quad \frac{A_{j} F_{i j} K_{i j}}{\sum_{i=1}\left(A_{j} F_{i j} K_{i j}\right)}
$$

Intervening Opportunities Model

The intervening opportunities model assumes that the trip interchange between an origin and a destination zone is equal to the total trips emanating from the origin multiplied by the probability that each trip origin will find an acceptable terminal at the destination. This is expressed as follows:

$$
T_{i j}=0_{i} P\left(D_{j}\right)
$$

where:

$$
\begin{aligned}
& T_{i j}= \begin{array}{l}
\text { the trips between origin zone } i \text { and } \\
\text { destination zone } j,
\end{array} \\
& 0_{i}=\begin{array}{l}
\text { the total trip origins produced at } \\
\text { zone } i,
\end{array} \\
& D_{j}=\begin{array}{l}
\text { the total trip destinations attracted } \\
\text { to zone } j,
\end{array} \\
& P\left(D_{j}\right)=\begin{array}{l}
\text { the probability that each trip origin at } i \\
\text { will find destination } j \text { an acceptable ter- } \\
\text { minal. }
\end{array}
\end{aligned}
$$

$P\left(D_{j}\right)$, the probability that each trip origin at $i$ will find destination at $j$ an acceptable terminal, is expressed as a function of $D_{j}$, which is the total trip destinations attracted to zone $\mathrm{j} . D_{j}$ is used because the model assumes that two zonal characteristics determine the probability that a destination will be acceptable. They are the size of the destination and the order in which it is encountered as trips proceed away from the origin (ibid., pp. IV-62 - IV-65).

The standard form of the model is:

$$
T_{i j}=o_{i}\left(e^{-L B}-e^{-L A}\right)
$$


where:

$$
\begin{aligned}
& A=\text { the sum of all destinations for zones } \\
& \text { between, in terms of closeness, } i \text { and } \\
& j \text { and including } j \text {, } \\
& B=\text { the sum of all destinations for zones } \\
& \text { between } i \text { and } j \text { but excluding } j \text {, } \\
& \mathrm{e}=\text { the constant base of natural logarithms, } \\
& 2.71828 \text {. . . , } \\
& L=\text { the probability density (probability per } \\
& \text { destination) of destination acceptability } \\
& \text { at the point of consideration. }
\end{aligned}
$$

One of this model requirements is that "destination zones be ordered according to their nearness in time to the origin being considered. Thus, destinations are in sequence according to the contents of the skim tree associated with the origin" (U.S. Department of Transportation, Federal Highway Administration, March, 1972, p. IV-64).

Both models require trip ends-trip productions $\left(P_{i}\right.$ or $\left.0_{i}\right)$ and attractions ( $A$ or $A$ and $B$ ), impedance values $\left(F_{i j}\right.$ or $L A$ and $L B$ as based on skim tree) and an iterative process to ensure that the calculated destination totals approach the desired values--balancing the trip end volumes.

Similar developments, regarding these two models, can be found in rieanue and Pyers (1966), and Whitaker and West (1968).

\section{Systems Theory Model}

.. The system theory model is a procedure for constructing a system analog. One can think of an electric anaiog, where the origin acts like current sources. The current (for example, flow of campers) sees various paths of differing resistance and distributes itself across the network in a minimum-energy fashion, eventualiy returning 
to ground via the park components. The flow at each park is thus determined by the relative resistance of all parks, all links and the relative strengths of a 11 origin sources (Alan M. Voorhees \& Associates, Inc., October, 1973, P. VI13).

Moreover, the model

- . comprises three classes of components, each modeled in a different way:

$$
\begin{aligned}
& \text { Generating areas or origins } \\
& \text { Highway segments and } \\
& \text { Destination areas. . . . }
\end{aligned}
$$

Each class of components is described by a particular equation appropriate in form to the class, the parameters of which are determined individually for each component in the class. The influence of other components do not affect the component modeling equation for any particular component. The mutual influences and interactions of components are considered to be due only to the interconnection of the components and not to their actual nature.

The origin area components were considered to act as sources of specified traffic flows and the form of the equation is:

$$
Y_{0}=\text { known }
$$

where:

the known flow is the number of trips actually determined to have origirated in a given area.

The destination areas were considered to attract trips in direct proportion to their attractiveness for the activity being carried on. The form of the equation is:

$$
y_{d}=A_{d} X_{d}
$$

where:

$$
A_{d}=\text { attraction index. }
$$

Basically the $Y$ variable is the flow, or number, of trips and the $X$ variable is the demand pressure or propensity to travel. 
The highway links were modeled on a resistance basis. Their equation took the form of:

$$
y=\frac{k_{i} x}{R}
$$

where:

$R$ is the apparent travel resistance of the link and $K_{1}$ is a constant. The link resistance can be further formulated as:

$$
R=\left(T+K_{2} C\right)^{K_{3}}
$$

where:

$K_{2}$ and $K_{3}$ are constants, $T$ is the average driving time in hours for the highway segment and $C$ is the average direct costs of vehicle separation over the link in dollars.

The method of combining the above equation, one for each component in the system, is based upon iinear graph methods. (McLaughtin, 1966). A new set of simultaneous system equations result which can be solved for a11 pressures and flows in the system. Due to its simultaneous nature it can also be further solved to determine the flows on each network link. Thus, it can be used as an assignment technique as wel1 (ibid., pp. VI-14 - VI-15). 


\section{APPENDIX D}

\section{TRIP INTERCHANGES $\left(T_{i j}\right)$ FOR PORTLAND, EUGENE/SPRINGFIELD AND SALEM SUBAREAS}

Trip interchanges, $T_{i j}$, are needed for the model calibration. Except Portland, Eugene/Springfield and Salem subareas, the $T_{i j}$ were derived by simply applying the sample rate(s) by place of residence (county and urban area) to the respective camper registration data. The camper registration data are differentiated by the campground and the camper county of residence. For the Portland, Eugene/Springfield and Salem subareas, the sample rates, differentiated by subareas of residence, were muitiplied by the respective camper registration data in order to establish Portland, Eugene/Springfield and Salem subareas' $T_{i j}$ for 1975 .

In addition, the $T_{i j}$ for 1973 , needed to validate the model, were derived for Portland subareas. These were obtained in the similar manner as the $1975^{\prime} \mathrm{s} \mathrm{T}_{i j}$; however, it was assumed that since no substantial changes were noted in the travel patterns during the 19701973 period, the 1973 camper registration data and the 1970 park survey information (obtained in the similar manner as 1975 survey) would be used to obtain the 1973 Port7and subareas' $T_{i j}$. The share method was used in both the 1973 and $1975 T_{i j}$ computations.

The camper registration information is reported in terms of camper nights, number of nights-time-spent at a site. It was necessary to convert it to $T_{i j}$ as follows:

$$
T_{i j}=\frac{C R D}{A C N}
$$


where:

$$
\begin{aligned}
& \mathrm{CRD}=\text { camper registration data, } \\
& \mathrm{ACN}=\text { average camper nights. }
\end{aligned}
$$

For this study, the value of $A C N$ is 2.50 nights. This number is derived from tabulations shown below, Table XIII.

For Portland subareas, the $T_{i j}$ is a matrix of $20 \times 16$ (sixteen sites and 20 subareas). It also is a $20 \times 16$ matrix for the rest of the urban areas (see Figure 1), including the six subareas of Salem and Eugene/Springfield.

TABLE XIII

LENGTH OF STAY AT A CAMPSITE*

\begin{tabular}{|l|r|}
\hline Duration & Responses (\%) \\
\hline Less than three hours & 2.69 \\
$3-6$ hours & 7.48 \\
$7-12$ hours & 4.85 \\
$13-24$ hours & 11.97 \\
$1-3$ days (nights) & 52.27 \\
$4-7$ days & 20.83 \\
or more days & 5.91 \\
Total & 100.00 \\
\hline
\end{tabular}

*From 1975 Parks' Survey, Parks and Recreation Branch, Oregon Department of Transportation. 
APPENDIX E

\section{ANDERSON'S APPROACH TO INFORMATION INTEGRATION}

The approach taken to estimate one of the components of the site's attractiveness, site physical attribute preference, is based on information integration theory of judgment. This theory provides an answer to the theoretical question of "how the subject integrates the input from varied stimulus cues into a single judgment" (Anderson, 1974, p. 216). This approach is simple and direct. It establishes interval scales on both the stimulus side and the response side (Anderson, p. 221).

The theory and its assumptions, presented here, are from Anderson's various works.

\section{INFORMATION INTEGRATION}

. A conception of the organism as an integrator of stimulus information is time-honored in perception and judgment. Most judgments, if indeed not 211 , reflect several coacting stimuli that are combined or integrated to produce the response. Person perception is a good example. Our opinions about a person result from an integration of diverse pieces of information: personal interaction, direct observation, written records of diverse kinds, remarks of others. Person perception is not unique in this; evaluating a job offer, tasting a carbonated drink, catching a ball, all require information integration (Anderson, 1972, p. 3).

- . To translate this view to an experimental counterpart leads to a synthetic approach--studying how the several separate cues are combined or integrated into the overall percept (Anderson, 1974, p. 216). 


\section{ALGEBRAIC MODELS AND FUNCTIONAL MEASUREMENT}

Two aspects of the present approach deserve comment. One is the use of simple algebraic models to describe various integration processes. The other is a theory of functional measurement to get the subjective or psychological values of the stimulus variables (Anderson, 1972, p. 4).

\section{Algebraic Models}

- . The present theory makes systematic use of algebraic models of perception and judgment. A striking outcoine of the investigations has been the repeated finding that these simple models can give a detailed, quantitative account of fairly complex cognitive activity.

Most of the models fall in one of two main classes. One class includes adding, subtracting, and averaging models. Adding and subtracting are formaliy similar, of course, but may be psychologically different. Adding and averaging are different, both psychologically and mathematically. Under certain circumstances, they make identical predictions and have a very simple analys is (ibid, pp. 4-5).

- . Adding models can be used for spatial and temporal summation, subtracting models for preference and difference judgments, averaging models for bisection and for contrast effects, multiplying models for size constancy, and dividing models for ratio settings and for comparative judgment (Anderson, 1974, pp. 216-217).

More recently, the methods of integration theory have been extended to handle multiplying models and dividing models. Multiplying models arise in traditional utility theory, for example, and dividing models arise in comparative judgment (Anderson, 1972, p. 5).

- . These models have arisen naturally in a variety of experimental situations, and they are alike in specifying the response to be some simple algebraic function of the subjective values of the physical stimuli....

The algebraic model involves two basic psychological operations. One of these is the integration process itself, . . . . The other is the valuation process, by which the overt physical stimuli receive their subjective values, both scale value and weight (Anderson, 1974, p. 217). 
... One aspect of these algebraic models requires special notice. They are expressed in subjective metrics, or psychological values, of the response and of the stimuli. Many investigators have ignored the need for subjective metrics and have employed handy, arbitrary scales. That may suffice for certain purposes, but it can lead to serious misinterpretations (Anderson, 1971a, 1972a). Without the psychological values, a completely adequate treatment of the models is not possible.

To get the subjective metrics requires a theory of measurement, one of the more contentious areas of psychology. The present approach includes a theory of functional measurement that yields the subjective metrics in a simple way (Anderson, 1972, p. 5).

\section{Functional Measurement}

Functional measurement has a triple goal:

1. to measure the subjective values of the stimuli on interval scales,

2. to measure the subjective value of the response on an interval scale, and

3. to determine the psychological law relating stimuli and response.

These three goals are to be accomplished together. . . .

The guiding idea of functional measurement is that substantive theory is the foundation of measurement. This view leads to an orientation and approach that are in many ways exactly opposite to the customary approach. Too often, measurement is viewed as a methodological preliminary to substantive inquiry; only after the stimuli have been scaled does the study of the psychological law begin. In contrast, the functional view is that measurement is woven into the fabric and structure of the substantive laws. Measurement theory and substantive theory are organically related. They are cofunctional in development (Anderson, 1974, p. 218).

\section{EXAMPLES}

To illustrate, consider the response to a combination of two stimuli $S$, and $S_{2}$ (ibid, p. 217). 
. . The physical stimuli will be denoted by $S_{r i}$ and $S_{C j}$, where $R$ and $C$ stand for rows and columns of a twoway matrix or factorial design, and $i$ and $j$ index the levels of the row and column factors.

The simple linear model can then be written as

$$
R_{i j}=c_{0}+w_{r} s_{r i}+w_{c} s_{c j}+e_{i j},
$$

Here $R_{i j}$ is the response to the stimulus combination ( $S_{r i}, S_{c j}$ ); Sri and $S_{c j}$ are the (subjective) scale values of the stimuli $S_{r i}$ and $S_{c j}, w_{r}$ and $w_{e}$ are constant mathematical weighting parameters; and $C_{0}$ is a constant that allows for an arbitrary zero in the measured response. The additive error terms $e_{i j}$ represent response variability (ibid, , pp. 221-222).

If three stimulus variables were used, an exactly analogous form would be obtained:

$$
R_{i j k}=w_{R} S_{R i}+w_{C} S_{C j}+w_{L} S_{L k}+E_{i j k},
$$

where $w_{L}$ and SLk are the value and weight of the stimuli in the third, "Layer" stimulus variable (Anderson, 1972, p. 9).

\section{TESTS}

PARALLELISM TEST. Linear models are easily tested, both graphically and statistically. Because of its additive form, Eq. (1) leads directly to a prediction of parallelism. To illustrate, consider the difference between the entries in Rows 1 and 2 (with response variability neglected):

$$
\begin{aligned}
R_{1 j}-R_{2 j}= & c_{0}+w_{r} s_{r i}+w_{c} s_{c j} \\
& -c_{0}-w_{r} s_{r 2}-w_{c} s_{c j} .
\end{aligned}
$$

Cancellation yields

$$
R_{i j}-R_{2 j}=w_{r}\left(s_{r i}-s_{r 2}\right) \text {. }
$$

Since the right side of Eq. (2) is independent of the column index $j$, it follows that the difference between Rows 1 and 2 is the same constant in every coiumn. That is equivalent to parallelism in the graphical fortiil (Anderson, 1974, p. 223). 
ANALYSIS OF VARIANCE TEST. Ordinary analys is of variance can supplement the graphical test of parallelism with a rigorous statistical test. Equation (1) can readily be rewritten in the form of an additive model used in analysis of variance.... In that form, the statistical interaction terms are absent from the model. They should, therefore, be nonsignificant in the data analysis. The graphical test of paralTelism is equivalent to the statistical test of the Row $x$ Column interaction.

The analysis of variance generalizes directiy to any number of stimulus variables, a useful feature for preliminary screening of data from larger experiments (Anderson, 1974, p. 223).

. . . The test of goodness of fit between model and data does two things at once: It provides a joint validation of the model itself, and of the response scale. Unless the response measure was an "equal-interval" scale, it would produce discrepancies from parallelism for a correct model. Satisfactory fit testifies to the adequacy of the response measure. Validation of the model thus provides a functional scaling of the response (Anderson, 1972, p. 11).

\section{FUNCTIONAL SCALES/SUBJECTIVE STIMULUS VALUES}

If the model passes the test of fit, estimates of the subjective stimulus values are immediately available. These are simply the marginal means of the factorial design;... . The row means, for instance, estimate the scale values of the row stimuli on an interval scale. To see this, the marginal mean for Row $i$ can be obtained by averaging Eq. (1) over the other stimulus factors to yield

$$
R_{i .}=c_{0}+w_{r} s_{r i}+w_{c} \vec{s}_{c},
$$

or

$$
R_{i .}=w_{r} s_{r i}+\text { const. }
$$

Equation (3) states that the row mean is a linear function of the scale values of the row stimulus, and conversely. Within the model, therefore, the row means constitute an interval scale of the $\mathrm{s}_{\mathrm{ri}}$. 
In the data, therefore, the observed marginal means constitute estimates of the subjective values of the row stimuli on an interval scale. Given statistical independence and homogeneous variance (Scheffe', 1959), these are unbiased least squares estimated with minimum variance (Anderson, 1974, p. 224). 


\section{APPENDIX $F$}

COMPARISON OF SAMPIE AND SELECTED POPULATION INDICATORS:

TEST STATISTICS FOR THE PORTLAND URBANIZED AREA

Note: The numbers in parenthesis are percentages.

\section{A. Income*}

\begin{tabular}{|l|c|c|c|c|c|}
\hline Income groups & 1 & 2 & $3 *$ & 4 & \\
\hline $\begin{array}{l}\text { Portland } \\
\text { urbanized } \\
\text { area (PUA) }\end{array}$ & $\begin{array}{l}31,429 \\
(15.04)\end{array}$ & $\begin{array}{c}62,624 \\
(29.97)\end{array}$ & $\begin{array}{c}66,212 \\
(31.69)\end{array}$ & $\begin{array}{c}48,690 \\
(23.00)\end{array}$ & $\begin{array}{c}208,955 \\
(100.00)\end{array}$ \\
\hline Sample & $\begin{array}{c}29 \\
(13.18)\end{array}$ & $\begin{array}{c}69 \\
(31.36)\end{array}$ & $\begin{array}{c}78 \\
(35.45)\end{array}$ & $\begin{array}{c}44 \\
(20.00)\end{array}$ & $\begin{array}{c}220 \\
(100.00)\end{array}$ \\
\hline Tota1s & 31,458 & 62,693 & 66,290 & 48,734 & 209,175 \\
\hline
\end{tabular}

*This is a family income; it is extrapolated from 1960/1970 Census data. See Notations for the explanation of these groups.

$*$ Cells with the largest percentage difference between the sample and the population percentage.

B. Education*

\begin{tabular}{|l|c|c|c|c|c|}
\hline $\begin{array}{c}\text { Education } \\
\text { groups }\end{array}$ & 1 & 2 & 3 & 4 & \\
\hline PUA & $\begin{array}{c}76,120 \\
(19.50)\end{array}$ & $\begin{array}{c}171,756 \\
(44.00)\end{array}$ & $\begin{array}{c}74,168 \\
(19.00)\end{array}$ & $\begin{array}{c}68,315 \\
(17.50)\end{array}$ & $\begin{array}{c}309,359 \\
(100.00)\end{array}$ \\
\hline Sample & $\begin{array}{c}36 \\
(16.36)\end{array}$ & $\begin{array}{c}102 \\
(46.36)\end{array}$ & $\begin{array}{c}48 \\
(21.82)\end{array}$ & $\begin{array}{c}34 \\
(15.45)\end{array}$ & $\begin{array}{c}220 \\
(99.99)\end{array}$ \\
\hline Tota1s & 76,156 & 171,858 & 74,216 & 68,349 & 390,579 \\
\hline
\end{tabular}

*Extrapolated data from 1960/1970 information about education from the Census data. See Notations for the explanation of these groups. 
C. Occupation*

\begin{tabular}{|l|c|c|c|c|}
\hline $\begin{array}{l}\text { Occupation } \\
\text { categories }\end{array}$ & 1 & 2 & 3 & \\
\hline PUA & $\begin{array}{c}47,012 \\
(14.00)\end{array}$ & $\begin{array}{c}188,047 \\
(56.00)\end{array}$ & $\begin{array}{c}100,739 \\
(30.00)\end{array}$ & $\begin{array}{c}335,798 \\
(100.00)\end{array}$ \\
\hline Sample & $\begin{array}{c}32 \\
(14.55)\end{array}$ & $\begin{array}{c}119 \\
(54.09)\end{array}$ & $\begin{array}{c}69 \\
(31.36)\end{array}$ & $\begin{array}{c}220 \\
(100.00)\end{array}$ \\
\hline Totals & 47,044 & 188,166 & 100,808 & 336,018 \\
\hline
\end{tabular}

*Extrapolated data from 1960/1970 information provided in Census of Population. See Notations for the explanation of these groups.

Notations:

1. Income

\begin{tabular}{|c|c|}
\hline $\begin{array}{c}\text { Income } \\
\text { levels }\end{array}$ & $\begin{array}{c}\text { Income } \\
\text { groups }\end{array}$ \\
\hline 5,000 & 1 \\
$5,000-9,999$ & 2 \\
$10,000-14,999$ & 3 \\
15,000 or over & 4 \\
& \\
\hline
\end{tabular}

2. Education

\begin{tabular}{|l|c|}
\hline $\begin{array}{c}\text { Education } \\
\text { levels }\end{array}$ & $\begin{array}{c}\text { Education } \\
\text { groups }\end{array}$ \\
\hline Some high school & 1 \\
High school graduate & 2 \\
Some college & 3 \\
College graduate or & 4 \\
more & \\
\hline
\end{tabular}

3. Occupation

\begin{tabular}{|c|c|c|}
\hline $\begin{array}{l}\text { Occupation } \\
\text { categories }\end{array}$ & Indexes* & $\begin{array}{l}\text { Occupation } \\
\text { groups }\end{array}$ \\
\hline $\begin{array}{l}\text { Farm workers } \\
\text { Service workers }\end{array}$ & $\begin{array}{l}95.2,95.10 \\
95.8,95.9\end{array}$ & 1 \\
\hline White collar workers & $\begin{array}{l}95.1,95.3,95.4, \\
95.5\end{array}$ & 2 \\
\hline Blue collar workers & $95.6,95.7,95.11$ & 3 \\
\hline
\end{tabular}

*See next page for these indexes' explanation. 
Portland Urbanized Area: 1900/70 Census of Population Classified Index of Occupations

\begin{tabular}{|l|l|r|r|}
\hline $\begin{array}{c}\text { Classified } \\
\text { Index }\end{array}$ & Occupation Categories & 1970 & 1960 \\
\hline 95.1 & Professional & 48,323 & 31,425 \\
95.3 & Manager and administrators & 31,212 & 26,582 \\
95.5 & Sales worker & 27,485 & 24,001 \\
95.4 & Clerical and kindred wurkers & 63,756 & 44,717 \\
95.6 & $\begin{array}{l}\text { Craftsmen, foreman, kindred } \\
\text { workers }\end{array}$ & 37,703 & 33,579 \\
95.7 & Operatives, transport equip- & 29,373 & 37,911 \\
95.11 & ment operatives & 12,007 & 13,039 \\
95.2 & Labors & 506 & 57,054 \\
95.10 & Farmers and farm managers & 1,206 & 1,019 \\
95.9 & Farm laborers and farm & 37,559 & 24,808 \\
95.8 & foremen & 3,108 & 5,267 \\
\hline
\end{tabular}


APPENDIX G

QUESTIONNAIRE: SITE ATTRIBUTES AND MIXES OF ACTIVITIES

This appendix contains the questionnaire submitted to a convenience sample of the population of Portland, Oregon. The information obtained from the sampled subjects was used to derive the two components of site attractiveness, $A_{j}$, as explained earlier (pp. 67-83).

The questionnaire is divided into two parts: (1) questions dealing with information integration for site attributes (pp. 136-143), and (2) questions related to paired comparisons for mixes of activities (pp. 144-164). This latter set of questions was further subdivided into three subgroups. The pairs making up each subgroup were randomiy selected. Subgroup one ranges from page 144 to page 150. Subgroup two covers pages from 151 to 157 , while pages from 158 to 164 dea 7 with subgroup three. 


\section{QUESTION SET 1}

A. Instruction

Below is a list of 27 descriptions of possible recreationai sites or parks in Oregon. We would like you to indicate, for each site described, how likely you would be to visit that type of recreational site, using a value between zero percent (0\%) and one-hundred percent (100\%).

In the process of assigning the values to these recreational sites, each described site must be considered individually and independently of all the others: do not check back on your assigned values!

\section{B. Example}

If you rate a park $100 \%$ that indicates that you highly prefer such a site as described and you would always choose to visit it, while $0 \%$ indicates a site (as described) that you do not value--a site you would never choose to visit. For example, if in your opinion a described recreational area has "too many" improved campsites (as described) and located "too near" (as described) other activities, it would be rated toward zero percent (0\%). If, on the other hand, a described park is attractive to you because it has "only a few" primitive campsites (as described and located "near" (as described) other activities, then it should receive a rating toward the one-hundred percent (100\%).

NOTE: a. Other recreation activities are picnicking, motor fishing and hiking. 
b. A primitive campsite is a campsite with only pit toilets and water; $\$ 2.00$ fees. An unimproved campsites is a campsite with flush toilets and water; $\$ 3.00$ fees. An improved campsite is a campsite with flush toilets, water, elertricity, shower, $\ldots \$ 4.00$ fees.

\begin{tabular}{|l|l|l|}
\hline No. & DESCRIPTION OF A POSSIELE RECREATION SITE & RATE (\%) \\
\hline 1 & $\begin{array}{l}\text { A site with one (1) to fifty (50) primitive campsites and } \\
\text { located less than one (1) mile irom other recreation acti- } \\
\text { vities. }\end{array}$ & \\
\hline 2 & $\begin{array}{l}\text { A site with one (1) to fifty (50) unimproved campsites and } \\
\text { located less than one (1) mile from other recreation acti- } \\
\text { vities. }\end{array}$ & $\begin{array}{l}\text { A site with one (1) to fifty (50) primitive campsites and } \\
\text { located one (1) mile to two (2) miles from other recrea - } \\
\text { tion activities. }\end{array}$ \\
\hline 3 & $\begin{array}{l}\text { A site with fifty-one (51) to one-hundred (100) unimproved } \\
\text { campsites and located less than one (1) mile from other } \\
\text { recreation activities. } \\
\text { A site with one-hundred and one (101) to one-hundred fifty } \\
\text { (150) improved campsites anci Iocated one (1) mile to two }\end{array}$ & \\
\hline 5 & (2) miles from other recreation activities & \\
\hline
\end{tabular}




\begin{tabular}{|c|c|c|}
\hline No. & DESCRIPTION OF A POSSIBLE RECREATION SITE & RATE \\
\hline 6 & $\begin{array}{l}\text { A site with one-hunctred and one (101) to one-hundred } \\
\text { fifty (150) unimproved campsites and located one (1) } \\
\text { mile to two (2) miles from other recreation activities. }\end{array}$ & \\
\hline 7 & $\begin{array}{l}\text { A site with fifty-one (51) to one-hundred (100) unim- } \\
\text { proved campsites and located two (2) miles to three } \\
\text { (3) miles from other recreation activities. }\end{array}$ & \\
\hline 8 & $\begin{array}{l}\text { A site with one (1) to fifty (50) improved campsites and } \\
\text { located one (1) mile to two (2) miles from other recrea- } \\
\text { tion activities. }\end{array}$ & \\
\hline 9 & $\begin{array}{l}\text { A site with one-hundred and one (101) to one-hundred } \\
\text { fifty (150) primitive campsites and located one (1) mile } \\
\text { to two (2) miles from other recreation activities. }\end{array}$ & \\
\hline 10 & $\begin{array}{l}\text { A site with one (1) to fifty (50) improved campsites and } \\
\text { located less than one (1) mile from other recreation } \\
\text { activities. }\end{array}$ & \\
\hline 11 & $\begin{array}{l}\text { A site with one (1) to fifty (50) unimproved campsites } \\
\text { and located two ( } 2) \text { miles to three ( } 3 \text { ) miles from other } \\
\text { recreation activities. }\end{array}$ & \\
\hline 12 & $\begin{array}{l}\text { A site with fifty-one }(5 i) \text { to one-hundred (100) primitive } \\
\text { campsites and located one (1) mile to two (2) miles from } \\
\text { other recreation activities. }\end{array}$ & \\
\hline
\end{tabular}




\begin{tabular}{|c|c|c|}
\hline No. & DESCRIPTION OF A POSSIBLE RECREATION SITE & RATE \\
\hline 13 & $\begin{array}{l}\text { A site with one-hundred and one (101) to one-hundred } \\
\text { fifty (150) primitive campsites and located two ( } 2) \\
\text { miles to three (3) miles from other recreation acti- } \\
\text { vities. }\end{array}$ & \\
\hline 14 & $\begin{array}{l}\text { A site with fifty-one (51) to one-hundred (100) primi- } \\
\text { tive campsites and located two (2) miles to three ( } 3 \text { ) } \\
\text { miles from other recreation activities. }\end{array}$ & \\
\hline 15 & $\begin{array}{l}\text { A site with fifty-one (51) to one-hundred (100) primi- } \\
\text { tive campsites and located less than one (1) mile } \\
\text { from other recreation activities. }\end{array}$ & \\
\hline 16 & $\begin{array}{l}\text { A site with fifty-one (51) to one-hundred (100) unim- } \\
\text { proved campsites and located one (1) mile to two (2) } \\
\text { miles from other recreation activities. }\end{array}$ & \\
\hline 17 & $\begin{array}{l}\text { A site with fifty-one (51) to one-hundred (100) improved } \\
\text { campsites and located two (2) miles to three (3) miles } \\
\text { from other recreation activities. }\end{array}$ & \\
\hline 18 & $\begin{array}{l}\text { A site with fifty-one (51) to one-hundred (100) improved } \\
\text { campsites and located one (1) mile to two (2) miles } \\
\text { from other recreation activities. }\end{array}$ & \\
\hline 19 & $\begin{array}{l}\text { A site with one (1) to fifty }(50) \text { improved campsites and } \\
\text { located two (2) miles to thrce (3) miles from other re- } \\
\text { creation activities. }\end{array}$ & \\
\hline
\end{tabular}


140

\begin{tabular}{|c|c|c|}
\hline No. & DESCRIPTION OF A POSSIBLE RECREATION SITE & RATE \\
\hline 20 & $\begin{array}{l}\text { A site with one-hundred and one (101) to one-hundred } \\
\text { ficty (150) primitive campsites and located less than } \\
\text { one (1) mile from other recreation activities. }\end{array}$ & \\
\hline 21 & $\begin{array}{l}\text { A site with one (1) to fifty (50) primitive campsites } \\
\text { and located two (2) miles to three (3) miles from other } \\
\text { recreation activities. }\end{array}$ & \\
\hline 22 & $\begin{array}{l}\text { A site with one-hundred and one (101) to one-hundred } \\
\text { fifty (150) improved campsites and located less than } \\
\text { one (1) mile from other recreation activities. }\end{array}$ & \\
\hline 23 & $\begin{array}{l}\text { A site with one (1) to fifty (50) unimproved campsites } \\
\text { and located one (1) mile to two (2) miles from other } \\
\text { recreation activities. }\end{array}$ & \\
\hline 24 & $\begin{array}{l}\text { A site with one-hundred and one (101) to one-nundred } \\
\text { fifty (150) unimproved campsites and located two (2) } \\
\text { miles to three (3) miles from other recreation activi- } \\
\text { ties. }\end{array}$ & \\
\hline 25 & $\begin{array}{l}\text { A site with one-hundred and one (101) to one-hundred } \\
\text { fifty (150) improved campsites and located two (2) } \\
\text { miles to three (3) miles from other recreation activi- } \\
\text { ties. }\end{array}$ & \\
\hline 26 & $\begin{array}{l}\text { A site with one-hundred and one (101) to one-hundred } \\
\text { fifty (150) unimproved campsites and located less than } \\
\text { one (1) mile from other recreation activities. }\end{array}$ & \\
\hline
\end{tabular}




\begin{tabular}{|l|l|c|}
\hline No. & DESCRIPTION OF A POSSIBLE RECREATION SITE & RATE \\
\hline 27 & $\begin{array}{l}\text { A site with fifty -one (51) to one-hundred (100) improved } \\
\text { campsites and located less than one (1) mile from other } \\
\text { recreation activities. }\end{array}$ & \\
\hline
\end{tabular}

\section{QUESTION SET 2}

Instructions

Please answer question below by checking the appropriate box.

Check only one.

Question

Which of the following do you consider first in making decisions about outdoor recreation (away from home):

The type of outdoor recreation activities that you might take part in.

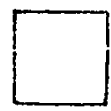

The site/park where you might go to take part in recreation activities

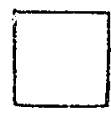

Facilities at the recreation sites that you migit visit.

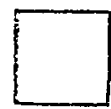

\section{QUESTION SET 3}

\section{A. Instructions}

To help us meet the requirements of the model, please answer the questions below. Note that your complete residence address is not necessary, but the general location of your residence is important. 
B. Example

For example: Portland, Northwest (NW), Lovejoy Street is enough for our purpose. In fact, the ZIP code number will do!

1. Your residence (Name of the city) (Street name or number) (Area of the city, N, NW, SW, SE, NE, ... if applicable)

OR your ZIP code number

2. Please indicate your formal education level by checking the appropriate box:

Some high school

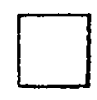

High school graduate

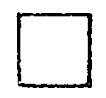

Some college

College graduate

Post graduate degree

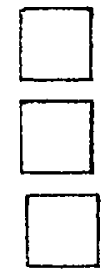

3. Please describe what you do in five or fewer words (example: typist, high school teacher, electrician, college professor, file clerk, medical doctor, planner, doorman, planer, foreman, piant manager, department store manager, ...) 
4. Please indicate your yearly family income (1975) before taxes by checking the appropriate box:

Less than $\$ 5,000$
$\$ 5,000-\$ 9,999$
$\$ 10,000-\$ 14,999$
$\$ 15,000-\$ 19,999$
$\$ 20,000$ or over

Comment(s)

Please feel free to make any comments about the recreation activities, sites/parks and this questionnaire.

Thank you for your help! 


\section{QUESTION SET 1}

\section{A. Instruction}

In the following list of 35 items (pairs), please check within each pair the one combination of outdoor recreation activities that you prefer. Note that all the combinations involve camping. Select only one (combination) of the two choices on each line (pair). Be sure to compare both combinations before choosing one.

B. Example

For example, in the pair (item):

a. picnicking and fishing

b. motor boating and hiking

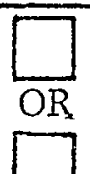

You would check the box next to the combination of activities that you prefer. Thus, in the example above, when you go camping, would you choose a park that includes picnicking and fishing facilities or motor boating and hiking facilities.

Repeat this process for all 35 pairs (items) below.

NOTE: Some "combinations of activities" may have just one activity, you will see as you go through this set of questions. 


\begin{tabular}{|c|c|c|}
\hline $\begin{array}{l}\text { Item/Pair } \\
\text { No. }\end{array}$ & Do you prefer camping with ... & CHOICE \\
\hline 1 & $\begin{array}{l}\text { a. picnicking } \\
\text { b. hiking and fishing }\end{array}$ & OR \\
\hline 2 & $\begin{array}{l}\text { a. picnicking } \\
\text { b. picnicking, hiking and fishing }\end{array}$ & OR \\
\hline 3 & $\begin{array}{l}\text { a. picnicking, hiking, fishing and motor boating } \\
\text { b. motor boating }\end{array}$ & OR \\
\hline 4 & $\begin{array}{l}\text { a. motor boating, picnicking and hiking } \\
\text { b. picnicking }\end{array}$ & OR \\
\hline 5 & $\begin{array}{l}\text { a. hiking and fishing } \\
\text { b. fishing }\end{array}$ & OR \\
\hline 6 & $\begin{array}{l}\text { a. picnicking, hiking and fishing } \\
\text { b. fishing and hiking }\end{array}$ & OR \\
\hline 7 & $\begin{array}{l}\text { a. hiking } \\
\text { b. picnicking and motor boating }\end{array}$ & OR \\
\hline 8 & $\begin{array}{l}\text { a. picnicking and hiking } \\
\text { b. hiking }\end{array}$ & OR \\
\hline 9 & $\begin{array}{l}\text { a. hiking } \\
\text { b. hiking, fishing and motor boating }\end{array}$ & OR \\
\hline 10 & $\begin{array}{l}\text { a. picnicking, hiking, fishing and motor boating } \\
\text { b. picnicking and hiking }\end{array}$ & OR \\
\hline
\end{tabular}


146

\begin{tabular}{|c|c|c|}
\hline $\begin{array}{l}\text { Item/Pair } \\
\text { No. }\end{array}$ & Do you prefer camping with ... & CHOICE \\
\hline 11 & $\begin{array}{l}\text { a. picnicking and motor boating } \\
\text { b. hiking, fishing and motor boating }\end{array}$ & OR \\
\hline 12 & $\begin{array}{l}\text { a. motor boating } \\
\text { b. picnicking, hiking and fishing }\end{array}$ & OR \\
\hline 13 & $\begin{array}{l}\text { a. picnicking and motor boating } \\
\text { b. fishing }\end{array}$ & $\mathrm{OR}$ \\
\hline 14 & $\begin{array}{l}\text { a. picnicking and fishing } \\
\text { b. hiking and motor boating }\end{array}$ & OR \\
\hline 15 & $\begin{array}{l}\text { a. hiking and fishing } \\
\text { b. fishing and motor boating }\end{array}$ & OR \\
\hline 16 & $\begin{array}{l}\text { a. hiking and motor boating } \\
\text { b. picnicking and motor boating }\end{array}$ & OR \\
\hline 17 & $\begin{array}{l}\text { a. picnicking and motor boating } \\
\text { b. picnicking }\end{array}$ & OR \\
\hline 18 & $\begin{array}{l}\text { a. motor boating } \\
\text { b. picnicking and fishing }\end{array}$ & OR \\
\hline 19 & $\begin{array}{l}\text { a. hiking, fishing and motor boating } \\
\text { b. motor boating and hiking }\end{array}$ & OR \\
\hline 20 & $\begin{array}{l}\text { a. hiking and motor boating } \\
\text { b. hikirg and fishing }\end{array}$ & OR \\
\hline
\end{tabular}




\begin{tabular}{|c|c|c|}
\hline $\begin{array}{l}\text { Item/Pair } \\
\text { No. }\end{array}$ & Do you prefer camping with ... & CHOICE \\
\hline 21 & $\begin{array}{l}\text { a. picnicking and hiking } \\
\text { b. fishing }\end{array}$ & OR \\
\hline 22 & $\begin{array}{l}\text { a. picnicking } \\
\text { b. hiking }\end{array}$ & OR \\
\hline 23 & $\begin{array}{l}\text { a. picnicking and motor boating } \\
\text { b. fishing, motor boating and picnicking }\end{array}$ & OR \\
\hline 24 & $\begin{array}{l}\text { a. fishing } \\
\text { b. picnicking }\end{array}$ & OR \\
\hline 25 & $\begin{array}{l}\text { a. picnicking and hiking } \\
\text { b. hiking, fishing and motor boating }\end{array}$ & OR \\
\hline 26 & $\begin{array}{l}\text { a. hiking and fishing } \\
\text { b. motor boating, picnicking and hiking }\end{array}$ & OR \\
\hline 27 & $\begin{array}{l}\text { a. fishing, motor boating and picnicking } \\
\text { b. hiking, fishing and motor boating }\end{array}$ & OR \\
\hline 28 & $\begin{array}{l}\text { a. picnicking and hiking } \\
\text { b. motor boating }\end{array}$ & OR \\
\hline 29 & $\begin{array}{l}\text { a. picnicking and hiking } \\
\text { b. picnicking }\end{array}$ & OR \\
\hline 30 & $\begin{array}{l}\text { a. picnicking } \\
\text { b. picnicking and fishìng }\end{array}$ & OR \\
\hline
\end{tabular}




\begin{tabular}{|c|c|c|}
\hline $\begin{array}{l}\text { Item/Pair } \\
\text { No. }\end{array}$ & Do you prefer camping with ... & CHOICE \\
\hline 31 & $\begin{array}{l}\text { a. hiking, fishing and motor boating } \\
\text { b. motor boating }\end{array}$ & OR \\
\hline 32 & $\begin{array}{l}\text { a. picnicking and motor boating } \\
\text { b. fishing and motor boating }\end{array}$ & $\mathrm{OR}$ \\
\hline 33 & $\begin{array}{l}\text { a. fishing } \\
\text { b. picnicking, hiking, fishing and motor boating }\end{array}$ & OR \\
\hline 34 & $\begin{array}{l}\text { a. picnicking } \\
\text { b. fishing and motor boating }\end{array}$ & OR \\
\hline 3.5 & $\begin{array}{l}\text { a. picnicking, hiking and fishing } \\
\text { b. picnicking and fishing }\end{array}$ & OR \\
\hline
\end{tabular}

\section{QUESTION SET 2}

$\underline{\text { Instructions }}$

Please answer question below by checking the appropriate box.

Check only one.

Question

Which of the following do you consider first in making decisions about outdoor recreation (away from home):

The type of outdoor recreation activities that you might take part in.

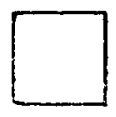

The site/park where you might go to take part in recreation activities.

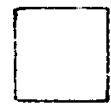


Facilities at the recreation sites that you might visit.

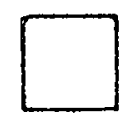

\section{QUESTION SET 3}

\section{A. Instructions}

To help us meet the requirements of the model, please answer the questions below. Note that your complete residence address is not necessary, but the general location of your residence is important.

B. Example

For example: Portland, Northwest (NW), Lovejoy Street is enough for our purpose. In fact, the ZIP code number will do!

1. Your residence (Name of the city) (Street name or number) (Area of the city, N, NW, $\mathrm{SW}, \mathrm{SE}, \mathrm{NE}, \ldots$ if applicable)

OR your ZIP code number

2. Please indicate your formal education level by ahecking the appropriate box:

Some high school

High school graduate
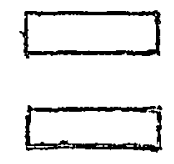

Some college

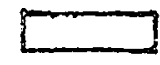

College graduate

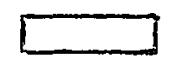

Post graduate degree

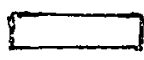


3. Please describe what you do in five or fewer words (example: typist, high school teacher, electrician, college professor, file clerk, medical doctor, planner, doorman, planer, foreman, plant manager, department store manager, ...)

4. Please indicate your yearly family income (1975) before taxes by checking the appropriate box:

Less than $\$ 5,000$
$\$ 5,000-\$ 9,999$
$\$ 10,000-\$ 14,999$
$\$ 15,000-\$ 19,999$
$\$ 20,000$ or over

\section{Comment(s)}

Please feel free to make any comments about the recreation activities, sites/parks and this questionnaire.

Thank you for your help! 
I. QUESTION SET 1

\section{A. Instruction}

In the following list of 35 items (pairs), please check within each pair the one combination of outdoor recreation activities that you prefer. Note that all the combinations involve camping. Select only one (combination) of the two choices on each line (pair). Be sure to compare both combinations before choosing one.

B. Example

For example, in the pair (item):

a. picnicking and fishing

b. motor boating and hiking

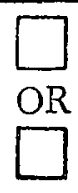

You would check the box next to the combination of activities that you prefer. Thus, in the example above, when you go camping, would you choose a park that includes picnicking and fishing facilities or motor boating and hiking facilities.

Repeat this process for all 35 pairs (items) below.

NOTE: Some "combinations of activities" may have just one activity, you will see as you go through this set of questions. 


\begin{tabular}{|c|c|c|}
\hline $\begin{array}{l}\text { Item/Pair } \\
\text { No. }\end{array}$ & Do you prefer camping with ... & CHOICE \\
\hline 1 & $\begin{array}{l}\text { a. fishing } \\
\text { b. fishing and motor boating }\end{array}$ & OR \\
\hline 2 & $\begin{array}{l}\text { a. hiking and motor boating } \\
\text { b. picnicking, hiking, fishing and motor boating }\end{array}$ & OR \\
\hline 3 & $\begin{array}{l}\text { a. motor boating, picnicking and hiking } \\
\text { b. picnicking, hiking, fishing and motor boating }\end{array}$ & OR \\
\hline 4 & $\begin{array}{l}\text { a. picnicking, hiking, fishing and motor boating } \\
\text { b. picnicking and fishing }\end{array}$ & OR \\
\hline 5 & $\begin{array}{l}\text { a. picnicking } \\
\text { b. picricking }\end{array}$ & OR \\
\hline 6 & $\begin{array}{l}\text { a. hiking and fishing } \\
\text { b. picnicking and hiking }\end{array}$ & OR \\
\hline 7 & $\begin{array}{l}\text { a. fishing, motor boating and picnicking } \\
\text { b. hiking }\end{array}$ & OR \\
\hline 8 & $\begin{array}{l}\text { a. picnicking, hiking and fishing } \\
\text { b. motor boating, picnicking and hiking }\end{array}$ & OR \\
\hline 9 & $\begin{array}{l}\text { a. picnicking and motor boating } \\
\text { b. picnicking and fishing }\end{array}$ & OR \\
\hline 10 & $\begin{array}{l}\text { a. fishing } \\
\text { b. hiking and motor boating }\end{array}$ & OR \\
\hline
\end{tabular}


153

\begin{tabular}{|c|c|c|}
\hline $\begin{array}{l}\text { Item/Pair } \\
\text { No. }\end{array}$ & Do you prefer camping with ... & CHOICE \\
\hline 11 & $\begin{array}{l}\text { a. hiking and motor boating } \\
\text { b. picnicking, hiking and fishing }\end{array}$ & OR \\
\hline 12 & $\begin{array}{l}\text { a. picnicking, hiking and fishing } \\
\text { b. picnicking, hiking, fishing and motor boating }\end{array}$ & OR \\
\hline 13 & $\begin{array}{l}\text { a. fishing, motor boating and picnicking } \\
\text { b. fishing }\end{array}$ & OR \\
\hline 14 & $\begin{array}{l}\text { a. fishing, motor boating and picnicking } \\
\text { b. picnicking and hiking }\end{array}$ & OR \\
\hline 15 & $\begin{array}{l}\text { a. motor boating and picnicking } \\
\text { b. picnicking, hiking and fishing }\end{array}$ & OR \\
\hline 16 & $\begin{array}{l}\text { a. Iishing and motor boating } \\
\text { b. picnicking and hiking }\end{array}$ & OR \\
\hline 17 & $\begin{array}{l}\text { a. hiking and motor boating } \\
\text { b. motor boating }\end{array}$ & OR \\
\hline 18 & $\begin{array}{l}\text { a. picnicking } \\
\text { b. picnicking, hiking, fishing and motor boating }\end{array}$ & OR \\
\hline 19 & $\begin{array}{l}\text { a. hiking } \\
\text { b. picnicking and fishing }\end{array}$ & OR \\
\hline 20 & $\begin{array}{l}\text { a. fishing, motor boating and picnicking } \\
\text { b. hiking and motor boating }\end{array}$ & OR \\
\hline
\end{tabular}




\begin{tabular}{|c|c|c|}
\hline $\begin{array}{l}\text { Item/Pair } \\
\text { No. }\end{array}$ & Do you prefer camping with ... & CHOICE \\
\hline 21 & $\begin{array}{l}\text { a. hiking, fishing and motor boating } \\
\text { b. fishing }\end{array}$ & OR \\
\hline 22 & $\begin{array}{l}\text { a. picnicking, hiking, fishing and motor boating } \\
\text { b. hiking }\end{array}$ & OR \\
\hline 23 & $\begin{array}{l}\text { a. picnicking and hiking } \\
\text { b. motor boating, picnicking and hiking }\end{array}$ & OR \\
\hline 24 & $\begin{array}{l}\text { a. motor boating, picnicking and hiking } \\
\text { b. picnicking and motor boating }\end{array}$ & OR \\
\hline 25 & $\begin{array}{l}\text { a. picnicking and motor boating } \\
\text { b. motor boating }\end{array}$ & OR \\
\hline 26 & $\begin{array}{l}\text { a. fissing, motor boating and picnicking } \\
\text { b. hiking and fishing }\end{array}$ & OR \\
\hline 27 & $\begin{array}{l}\text { a. motor boating } \\
\text { b. fishing, motor boating and picnicking }\end{array}$ & OR \\
\hline 28 & $\begin{array}{l}\text { a. motor boating and hiking } \\
\text { b. picnicking }\end{array}$ & OR \\
\hline 29 & $\begin{array}{l}\text { a. fishing } \\
\text { b. motor boating }\end{array}$ & OR \\
\hline 30 & $\begin{array}{l}\text { a. picnicking, hiking and fishing } \\
\text { b. hiking }\end{array}$ & OR \\
\hline
\end{tabular}




\begin{tabular}{|c|c|c|}
\hline $\begin{array}{l}\text { Item/Pair } \\
\text { No. }\end{array}$ & Do you prefer camping with ... & CHOICE \\
\hline 31 & $\begin{array}{l}\text { a. hiking, fishing and motor boating } \\
\text { b. picnicking, hiking and fishing }\end{array}$ & OR \\
\hline 32 & $\begin{array}{l}\text { a. motor boating, fishing, hiking and picnicking } \\
\text { b. hiking and fishing }\end{array}$ & OR \\
\hline 33 & $\begin{array}{l}\text { a. fishing } \\
\text { b. motor boating, picnicking and hiking }\end{array}$ & OR \\
\hline 34 & $\begin{array}{l}\text { a. motor boating and picnicking } \\
\text { b. fishing and hiking }\end{array}$ & OR \\
\hline 35 & $\begin{array}{l}\text { a. motor boating } \\
\text { b. picnicking }\end{array}$ & OR \\
\hline
\end{tabular}

\section{QUESTION SET 2}

\section{Instructions}

Please answer question below by checking the appropriate box.

Check only one.

Question

Which of the following do you consider first in making decisions about outdoor recreation (away from home):

The type of outdoor recreation activities that you might take part in.

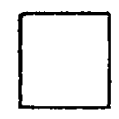

The site/park where you might go to take part in recreation activities

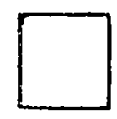


Facilities at the recreation sites that you might visit.

\section{QUESTION SET 3}

\section{A. Instructions}

To help us meet the requirements of the model, please answer the questions below. Note that your complete residence address is not necessary, but the general location of your residence is important.

\section{B. Example}

For example: Portland, Northwest (NW), Lovejoy Street is enough for our purpose. In fact, the ZIP code number will do!

1. Your residence (Name of the city) (Street name ox number) (Area of the city, N, NW, $\mathrm{SW}, \mathrm{SE}, \mathrm{NE}, \ldots$ if applicabie)

OR your ZIP code number

2. Please indicate your formal education level by checking the appropriate box:

Some high school

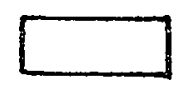

High school graduate

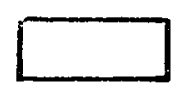

Some college

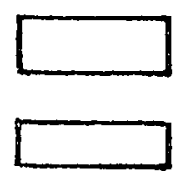

College graduate

Post graduate degree

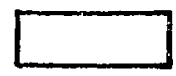


3. Please describe what you do in five or fewer words (example: typist, high school teacher, electrician, college professor, file clerk, medical doctor, planner, doorman, planer, foreman, plant manager, department store manager, ...)

4. Please indicate your yearly family income (1975) before taxes by checking the appropriate box:

Less than $\$ 5,000$
$\$ 5,000-\$ 9,999$
$\$ 10,000-\$ 14,999$
$\$ 15,000-\$ 19,999$
$\$ 20,000$ or over

Comment(s)

Please feel free to make any comments about the recreation activities, sites/parks and this questionnaire.

Thank you for your help! 


\section{QUESTION SET I}

\section{A. Instruction}

In the following list of 35 items (pairs), please check within each pair the one combination of outdoor recreation activities that you prefer. Note that all the combinations involve camping. Select only one (combination) of the two choices on each line (pair). Be sure to compare both combinations before choosing one.

B. Example

For example, in the pair (item):

a. picnicking and fishing

b. motor boating and hiking

You would check the box next to the combination of activities that you prefer. Thus, in the example above, when you go camping, would you choose a park that includes picnicking and fishing facilities or motor boating and hiking facilities.

Repeat this process for all 35 pairs (items) below.

NOTE: Some "combinations of activities" may have just one activity, you will see as you go through this set of questions. 


\begin{tabular}{|c|c|c|}
\hline $\begin{array}{l}\text { Item/Pair } \\
\text { No. }\end{array}$ & Do you prefer camping with ... & CHOICE \\
\hline 1 & $\begin{array}{l}\text { a. hiking } \\
\text { b. fishing and motor boating }\end{array}$ & OR \\
\hline 2 & $\begin{array}{l}\text { a. fishing and motor boating } \\
\text { b. picnicking and fishing }\end{array}$ & OR \\
\hline 3 & $\begin{array}{l}\text { a. picnicking and fishing } \\
\text { b. fishing, hiking and motor boating }\end{array}$ & OR \\
\hline 4 & $\begin{array}{l}\text { a. hiking, fishing and motor boating } \\
\text { b. hiking and fishing }\end{array}$ & OR \\
\hline 5 & $\begin{array}{l}\text { a. hiking, fishing and motor boating } \\
\text { b. fishing and motor boating }\end{array}$ & OR \\
\hline 6 & $\begin{array}{l}\text { a. fishing } \\
\text { b. hiking }\end{array}$ & OR \\
\hline 7 & $\begin{array}{l}\text { a. picnicking and fishing } \\
\text { b. motor boating, picnicking and hiking }\end{array}$ & OR \\
\hline 8 & $\begin{array}{l}\text { a. hiking, fishing and motor boating } \\
\text { b. picnicking, hiking, fishing and motor boating }\end{array}$ & OR \\
\hline 9 & $\begin{array}{l}\text { a. fishing, motor boating and picnicking } \\
\text { b. picnicking }\end{array}$ & OR \\
\hline 10 & $\begin{array}{l}\text { a. picnicking and motor boating } \\
\text { b. motor boating, fishing, hiking and picnicking }\end{array}$ & OR \\
\hline
\end{tabular}




\begin{tabular}{|c|c|c|}
\hline $\begin{array}{l}\text { Item/Pair } \\
\text { No. }\end{array}$ & Do you prefer camping with ... & CHOICE \\
\hline 11 & $\begin{array}{l}\text { a. fishing, motor boating and picnicking } \\
\text { b. picnicking and fishing }\end{array}$ & OR \\
\hline 12 & $\begin{array}{l}\text { a. fishing, motor boating and picnicking } \\
\text { b. picnicking, hiking, fishing and motor boating }\end{array}$ & OR \\
\hline 13 & $\begin{array}{l}\text { a. fishing } \\
\text { b. picnicking and fishing }\end{array}$ & OR \\
\hline 14 & $\begin{array}{l}\text { a. hiking } \\
\text { b. motor boating }\end{array}$ & OR \\
\hline 15 & $\begin{array}{l}\text { a. picnicking and hiking } \\
\text { b. motor boating and picnicking }\end{array}$ & OR \\
\hline 16 & $\begin{array}{l}\text { a. hiking and fishing } \\
\text { b. hiking }\end{array}$ & OR \\
\hline 17 & $\begin{array}{l}\text { a. motor boating, picnicking and hiking } \\
\text { b. motor boating }\end{array}$ & OR \\
\hline 18 & $\begin{array}{l}\text { a. picnicking, hiking and fishing } \\
\text { b. fishing, motor boating and picnicking }\end{array}$ & OR \\
\hline 19 & $\begin{array}{l}\text { a. motor boating, picnicking and hiking } \\
\text { b. hiking, fishing and motor boating }\end{array}$ & OR \\
\hline 20 & $\begin{array}{l}\text { a. hiking and motor boating } \\
\text { b. hiking }\end{array}$ & OR \\
\hline
\end{tabular}




\begin{tabular}{|c|c|c|}
\hline $\begin{array}{l}\text { Item/Pair } \\
\text { No. }\end{array}$ & Do you prefer camping with ... & CHOICE \\
\hline 21 & $\begin{array}{l}\text { a. hiking } \\
\text { b. motor boating, picnicking and hiking }\end{array}$ & OR \\
\hline 22 & $\begin{array}{l}\text { a. fishing and motor boating } \\
\text { b. motor boating }\end{array}$ & OR \\
\hline 23 & $\begin{array}{l}\text { a. fishing } \\
\text { b. picnicking, hiking and fishing }\end{array}$ & $\mathrm{OR}$ \\
\hline 24 & $\begin{array}{l}\text { a. picnicking and fishing } \\
\text { b. picnicking and hiking }\end{array}$ & OR \\
\hline 25 & $\begin{array}{l}\text { a. motor boating } \\
\text { b. hiking and fishing }\end{array}$ & OR \\
\hline 26 & $\begin{array}{l}\text { a. fishing, motor boating and picnicking } \\
\text { b. motor boating, picnicking and hiking }\end{array}$ & OR \\
\hline 27 & $\begin{array}{l}\text { a. fishing and motor boating } \\
\text { b. hiking and motor boating }\end{array}$ & OR \\
\hline 28 & $\begin{array}{l}\text { a. fishing and motor boating } \\
\text { b. picnicking, hiking, fishing and motor boating }\end{array}$ & OR \\
\hline 29 & $\begin{array}{l}\text { a. hiking and fishing } \\
\text { b. picnicking and fishing }\end{array}$ & OR \\
\hline 30 & $\begin{array}{l}\text { a. fishing and motor boating } \\
\text { b. picnicking, hiking and fishing }\end{array}$ & OR \\
\hline
\end{tabular}




\begin{tabular}{|c|c|c|}
\hline $\begin{array}{l}\text { Item/Pair } \\
\text { No. }\end{array}$ & Do you prefer camping with ... & CHOICE \\
\hline 31 & $\begin{array}{l}\text { a. hiking and motor boating } \\
\text { b. motor boating, picnicking and hiking }\end{array}$ & OR \\
\hline 32 & $\begin{array}{l}\text { a. picnicking and hiking } \\
\text { b. hiking and motor boating }\end{array}$ & OR \\
\hline 33 & $\begin{array}{l}\text { a. fishing and motor boating } \\
\text { b. fishing, motor boating and picnicking }\end{array}$ & OR \\
\hline 34 & $\begin{array}{l}\text { a. motor boating, picnicking and hiking } \\
\text { b. fishing and motor boating }\end{array}$ & OR \\
\hline 35 & $\begin{array}{l}\text { a. picnicking, hiking and fishing } \\
\text { b. picnicking and hiking }\end{array}$ & OR \\
\hline
\end{tabular}

\section{QUESTION SET 2}

\section{Instructions}

Please answer question below by checking the appropriate box.

Check only one.

Question

Which of the following do you consider first in making decisions about outdoor recreation (away from home):

The type of outdoor recreation activities that you might take part in.

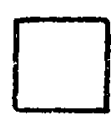

The site/park where you might go to take part in recreation activities.

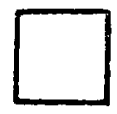


Facilities at the recreation sites that you might visit.

\section{QUESTION SET 3}

\section{A. Instructions}

To help us meet the requirements of the model, please answer the questions below. Note that your complete residence address is not necessary, but the general location of your residence is important.

B. Example

For example: Portland, Northwest (NW), Lovejoy Street is enough for our purpose. In fact, the ZIP code number will do!

1. Your residence (Name of the city) (Street name or number) (A rea of the city, N, NW, $\mathrm{SW}, \mathrm{SE}, \mathrm{NE}, \ldots$ if applicable)

OR your ZIP code number

2. Please indicate your formal education level by checking the appropriate box:

Some high school

High school graduate

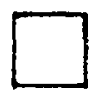

Some college

College graduate

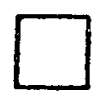

Post graduate degree
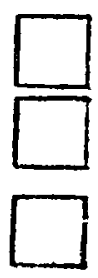
3. Please describe what you do in five or fewer words (example: typist, high school teacher, electrician, college professor, file clerk, medical doctor, planner, doorman, planer, foreman, plant manager, department store manager, ...)

4. Please indicate your yearly family income (1975) before taxes by checking the appropriate box:

Less than $\$ 5,000$

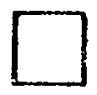

$\$ 5,000-\$ 9,999$

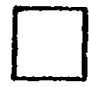

$\$ 10,000-\$ 14,999$

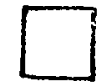

$\$ 15,000-\$ 19,999$

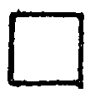

$\$ 20,000$ or over

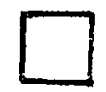

Comment(s)

Please feel free to make any comments about the recreation activities, sites/parks and this questionnaire.

Thank you for your help! 


\section{APPENDIX H}

MATRIX P: A $P \times P$ MATRIX

\begin{tabular}{|c|c|c|c|c|c|c|c|c|c|c|c|c|c|c|}
\hline R & 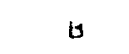 & $c$ & $v$ & 48 & $A C$ & $\Delta D$ & aC & Bi & סס & $A B C$ & $\triangle B U$ & $A C D$ & $\forall<0$ & $A \Delta C U$ \\
\hline $\begin{array}{l}0.6 \\
0.4706 \\
0.40011 \\
0.1591 \\
0.2059 \\
0.4118 \\
0.4151 \\
0.3952 \\
0.2877 \\
0.4231 \\
0.1504 \\
1.3373 \\
0.2870 \\
0.3023 \\
0.3453\end{array}$ & $\begin{array}{l}0.5294 \\
0.0 \\
0.4808 \\
0.3077 \\
0.2642 \\
0.2857 \\
0.3774 \\
0.31119 \\
0.0 \\
0.4615 \\
0.1170 \\
0.3 \times 22 \\
0.0105 \\
0.3774 \\
0.3468\end{array}$ & $\begin{array}{l}0.6000 \\
1.5192 \\
0.0 \\
0.1451 \\
0.3200 \\
0.1829 \\
1.44115 \\
1.2453 \\
1.2501 \\
1.3541 \\
0.1564 \\
0.3510 \\
0.4752 \\
3.4945 \\
0.2145\end{array}$ & $\begin{array}{l}0.3407 \\
1.5423 \\
0.3049 \\
1.01 \\
0.2353 \\
0.2500 \\
0.1541 \\
0.2549 \\
0.1905 \\
0.2400 \\
0.1881 \\
0.2075 \\
0.0750 \\
0.02011 \\
1.1321\end{array}$ & $\begin{array}{l}0.7941 \\
0.7557 \\
0.0800 \\
0.7647 \\
0.0 \\
0.4314 \\
0.3962 \\
0.4604 \\
0.3654 \\
0.0 \\
0.3259 \\
1.3415 \\
0.3953 \\
0.4114 \\
0.4609\end{array}$ & $\begin{array}{l}0.5012 \\
0.7143 \\
0.3302 \\
0.7500 \\
0.5686 \\
0.0 \\
0.2326 \\
0.4615 \\
1.4231 \\
0.2092 \\
0.1951 \\
0.4717 \\
0.4343 \\
0.0 \\
0.4045\end{array}$ & $\begin{array}{l}0.5445 \\
1.0226 \\
0.5094 \\
0.7459 \\
0.6038 \\
0.7674 \\
0.0 \\
0.1900 \\
0.4231 \\
0.4286 \\
0.1628 \\
0.2303 \\
0.4400 \\
0.3269 \\
0.1534\end{array}$ & $\begin{array}{l}0.0038 \\
0.6731 \\
0.7547 \\
0.7451 \\
0.5116 \\
0.5395 \\
0.8140 \\
0.0 \\
0.3259 \\
0.3208 \\
0.2042 \\
0.4118 \\
0.3023 \\
0.4902 \\
0.4136\end{array}$ & $\begin{array}{l}0.1143 \\
0.0 \\
0.7619 \\
0.8095 \\
0.0346 \\
0.5769 \\
0.5704 \\
0.0731 \\
0.0 \\
0.4400 \\
0.1395 \\
0.2151 \\
0.31000 \\
0.235 j \\
0.1190\end{array}$ & $\begin{array}{l}u .5169 \\
0.532 b \\
0.6429 \\
0.7600 \\
0.0 \\
0.7308 \\
0.5114 \\
0.6772 \\
0.5600 \\
0.0 \\
u .2549 \\
0.1137 \\
0.2157 \\
0.1765 \\
0.1800\end{array}$ & $\begin{array}{l}0.8491 \\
0.8810 \\
0.8431 \\
0.8113 \\
0.6731 \\
0.8039 \\
0.8372 \\
0.7358 \\
0.8605 \\
0.7451 \\
0.0 \\
0.2093 \\
0.4038 \\
0.2741 \\
0.3453\end{array}$ & $\begin{array}{l}0.6604 \\
0.0070 \\
0.0190 \\
0.7925 \\
0.6585 \\
0.05283 \\
0.7092 \\
0.2882 \\
0.7843 \\
0.6863 \\
0.7907 \\
0.0 \\
0.4400 \\
0.4510 \\
0.2857\end{array}$ & $\begin{array}{l}0.7170 \\
0.5014 \\
0.3238 \\
0.8744 \\
0.0047 \\
0.5660 \\
0.5600 \\
0.6977 \\
0.7000 \\
0.1843 \\
0.5962 \\
0.5600 \\
0.0 \\
0.4694 \\
0.1961\end{array}$ & $\begin{array}{l}0.0977 \\
0.0220 \\
0.5952 \\
0.0000 \\
0.5882 \\
0.0 \\
0.6731 \\
0.5090 \\
0.7647 \\
0.8235 \\
0.1204 \\
0.5490 \\
0.3300 \\
0.0 \\
0.2500\end{array}$ & $\begin{array}{l}0.6047 \\
0.6512 \\
0.7255 \\
0.8679 \\
0.5192 \\
0.5952 \\
0.8462 \\
0.5814 \\
0.8810 \\
0.8200 \\
0.6041 \\
0.7143 \\
0.8037 \\
0.7500 \\
0.0\end{array}$ \\
\hline
\end{tabular}

Notations:
$P=15$
$A=$ picnicking activity
$B=$ hiking activity
$C=$ fishing activity
$D=$ motor boating activity 


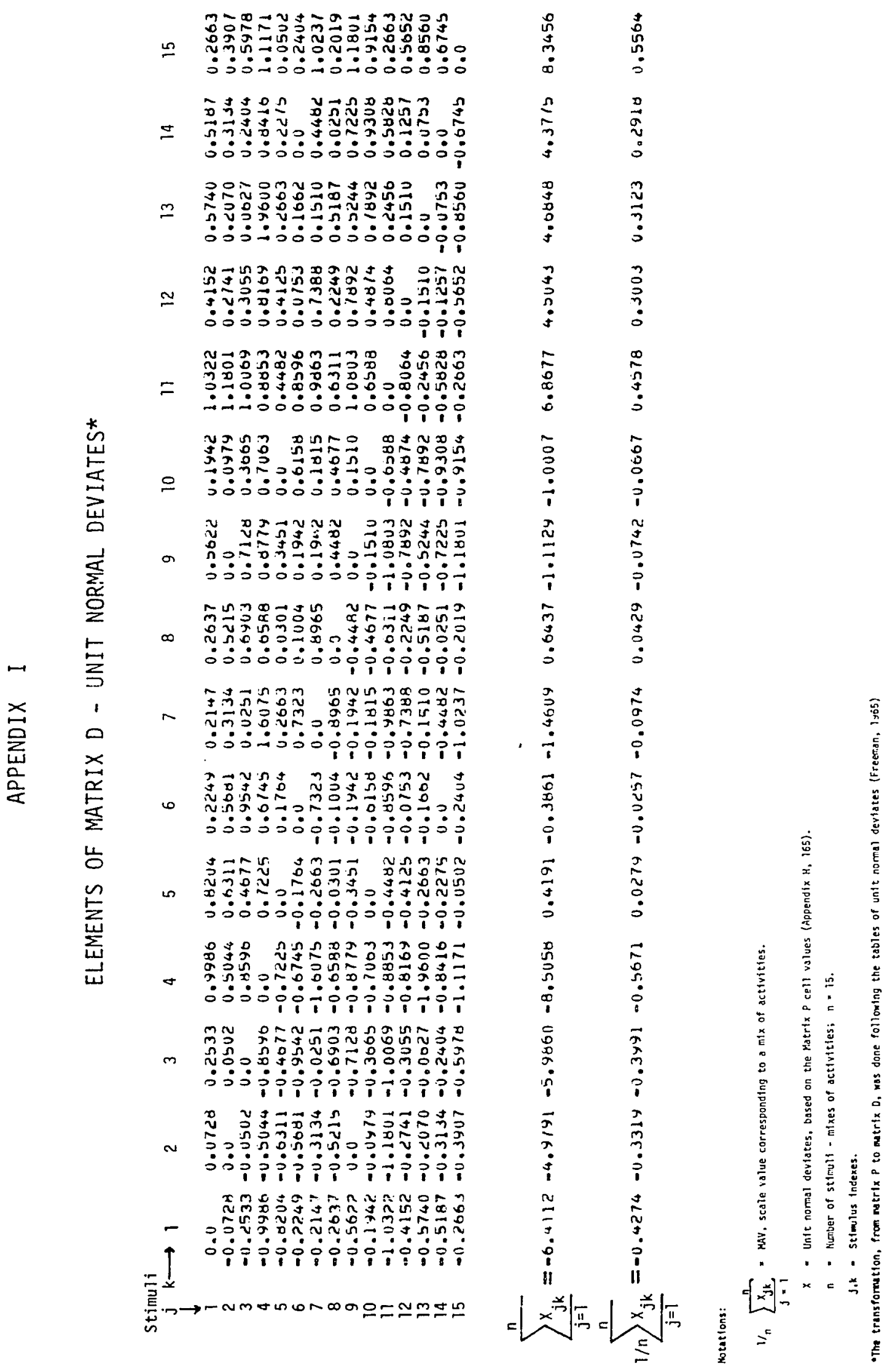




\section{APPENDIX $J$}

ANALYSIS OF VARIANCE TABLE, THREE-WAY FACTORIAL DESIGN:

COMPUTATION PROCEDURES RESULTING IN STATISTICS IN THE TABLE IV

A three-way classification model was tested, with fixed effects. The analysis was limited to the analysis of variance table that is separation of deviations and sum of squares from the grand mean into eight parts as discussed below:

(1) Let $Y_{i j k e}$ denote the $e^{\text {th }}$ response, given in Table XIV ( $p$. 168) to the stimulus interaction composed of the three site's attributes:

$$
\begin{aligned}
& A=\text { type of campsites : } i=1, \ldots . . \text {, a } \\
& \text { differentiated by costs (fee) } \\
& B=\text { amount of campsites: } j=1, \ldots . ., b \\
& C=\text { distance away from "other activities": } k=1 \text {, } \\
& \text {.. . c }
\end{aligned}
$$

$$
\text { where: } a=b=c=3 \text {, and } e=49 \text {. }
$$

(2) Given the means, average score values given in Table III (p. 74$)$.

Then, three two-way tables, shown below, are formed from means that are averaged over a single factor column means. $\bar{Y} \ldots$ is the grand mean.

$A / B$

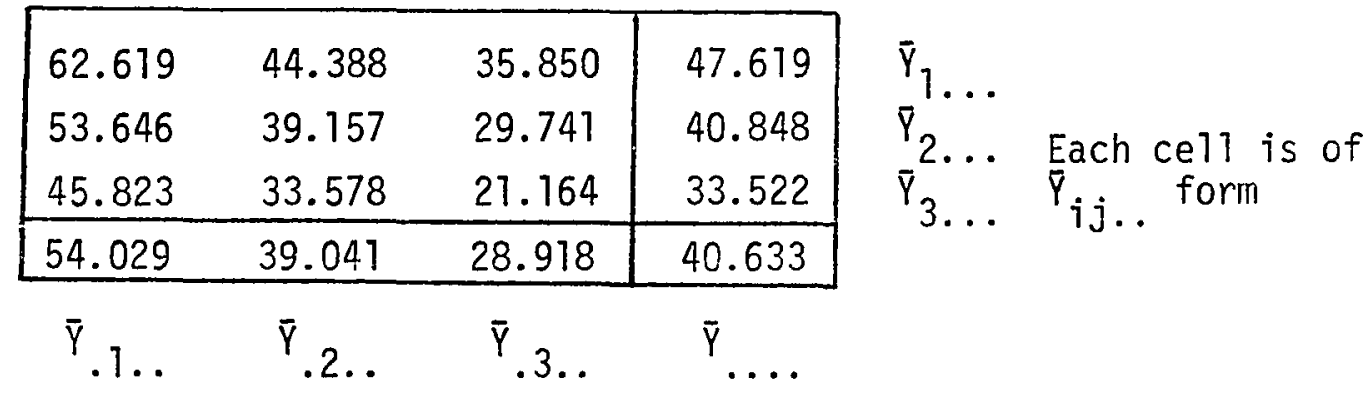


TABLE XIV

SUBJECTIVE SCORES (VALUES) FROM SITE'S ATTRIBUTE INTEGRATION RESPONSES-RAW DATA

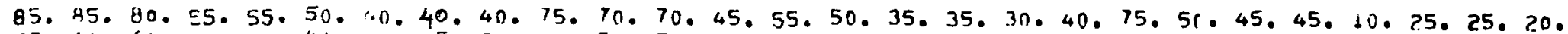
75. 5n. 60. $=0.40 \cdot 40 \cdot 4 n \cdot 35 \cdot 30 \cdot 55 \cdot 5 n \cdot 50 \cdot 45 \cdot 4 n \cdot 30 \cdot 3 n \cdot 25 \cdot 2 n \cdot 50 \cdot 45 \cdot 3 c \cdot 40 \cdot 3 n \cdot 2=\cdot 25 \cdot 20,15 \cdot$

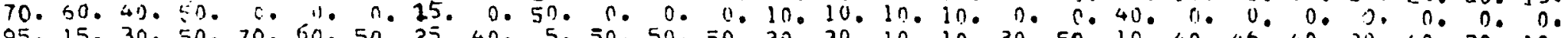
95. 15. 30.50.70.60.50.25.40.5.5n.50.50.30. 30.10.10.20.50.10.40.46.40.30.40.20.10.

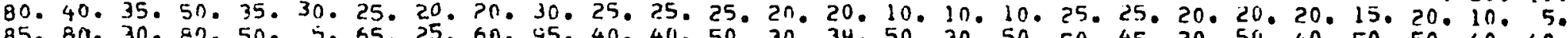
35. $80.30 .80 .50 .5 .65 .25,60.45 .40 .40,50.3 n, 34.50$.

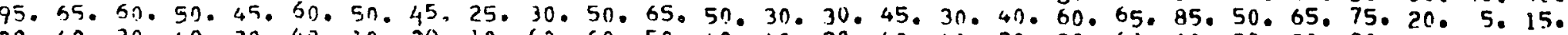

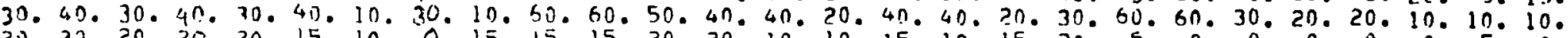

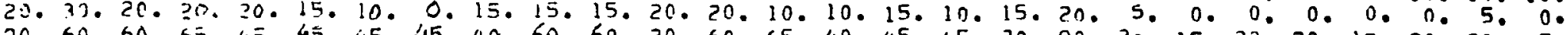

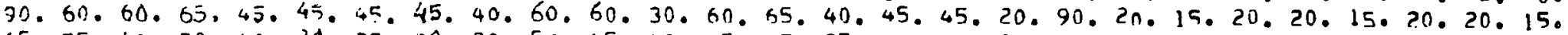

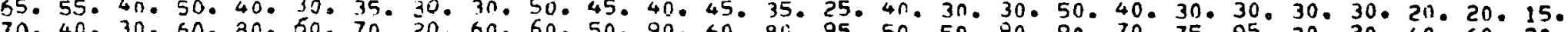

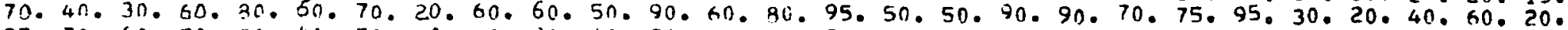

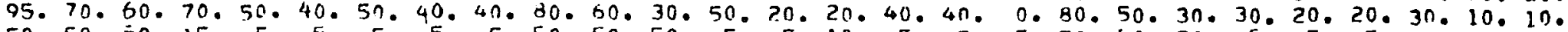

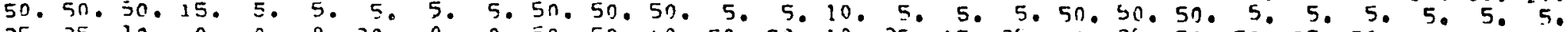

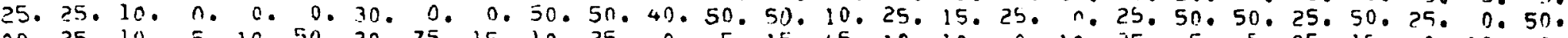

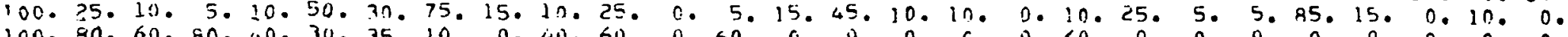

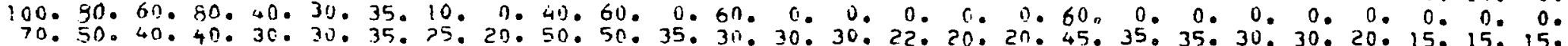

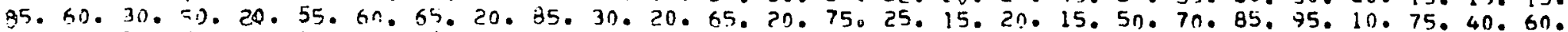

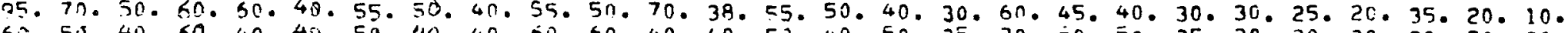

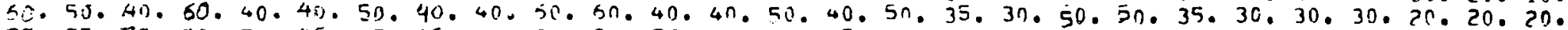

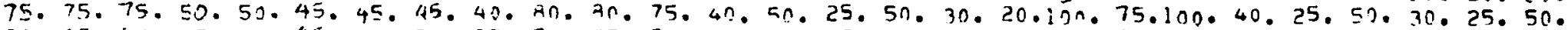

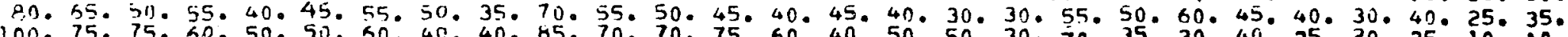

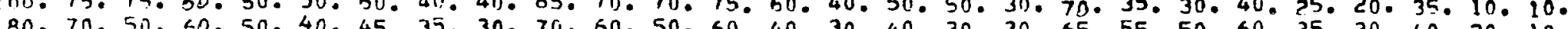

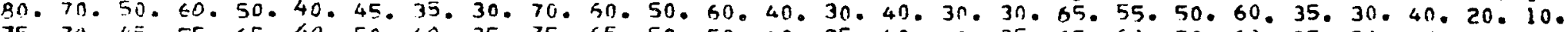

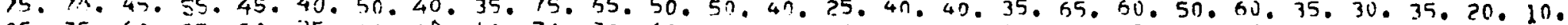

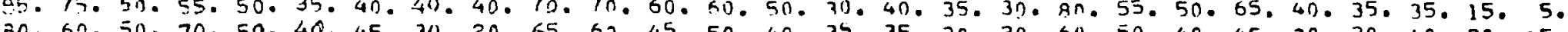

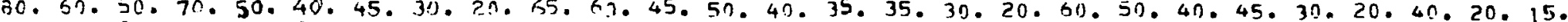

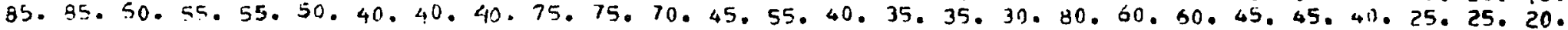


TABLE XIV (Con't.)

j\}

i]

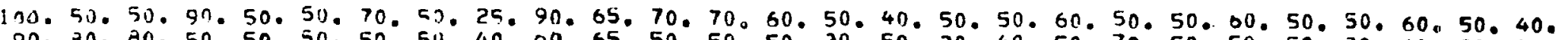

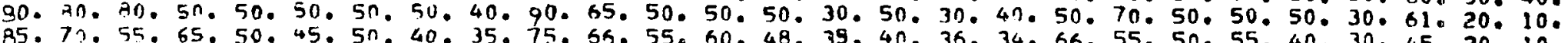

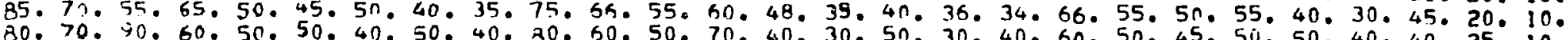

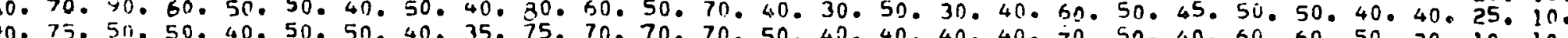

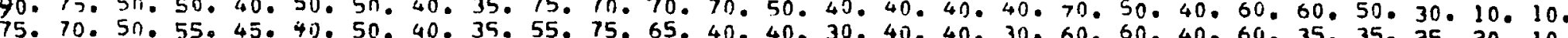

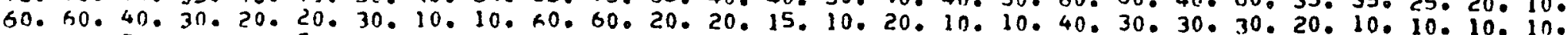

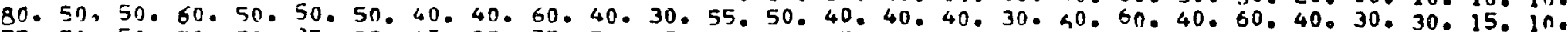

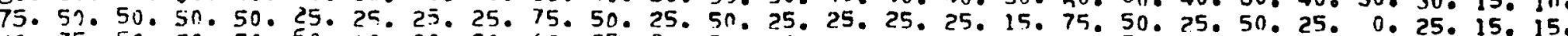

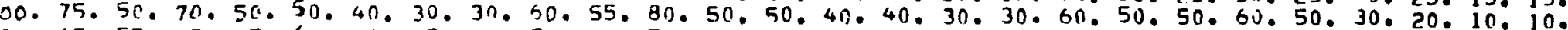

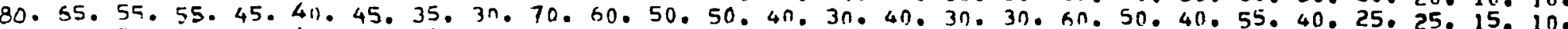

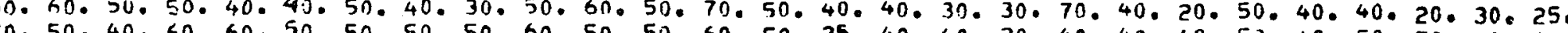

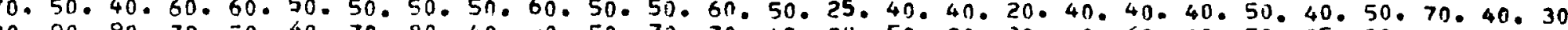

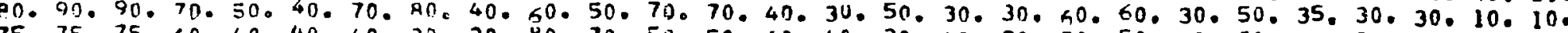

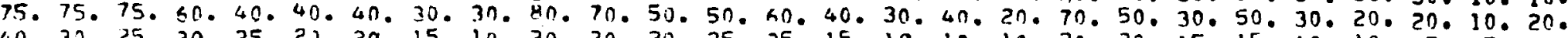

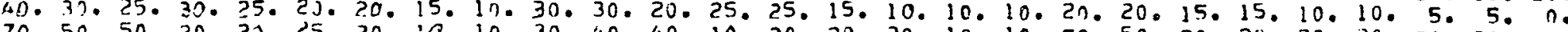

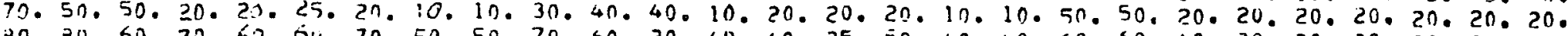

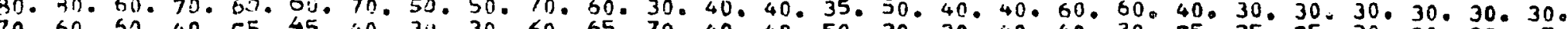

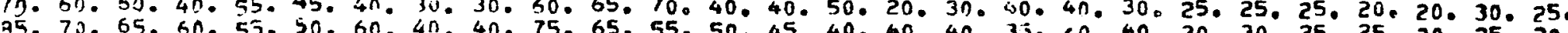

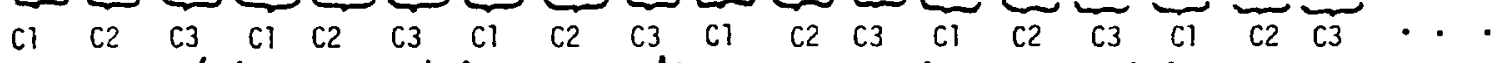

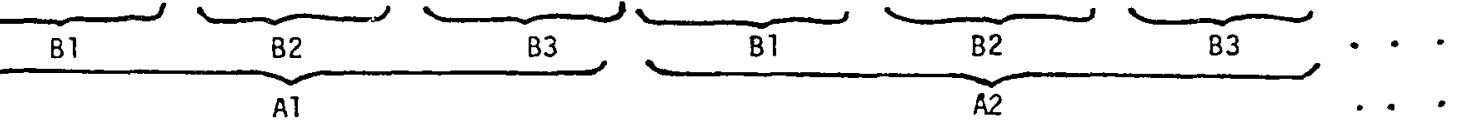


$B / C$

\begin{tabular}{|c|c|c|c|c|}
\hline 63.680 & 53.306 & 45.102 & 54.029 & $\overline{\mathrm{Y}}$ \\
\hline 46.354 & 38.150 & 32.619 & 39.041 & $\bar{Y}_{.2 .}$ \\
\hline 34.782 & 27.524 & 24.449 & 28.918 & $\bar{Y}_{3} \quad \bar{Y}{ }_{i k}$ form \\
\hline 48.272 & 39.660 & 34.057 & 40.663 & \\
\hline
\end{tabular}

C/A

\begin{tabular}{|c|c|c|c|c|}
\hline 57.347 & 46.735 & 40.735 & 48.272 & $\bar{Y}$ \\
\hline 45.850 & 40.476 & 32.653 & 39.660 & ₹.2. Each \\
\hline 39.660 & 35.333 & 27.177 & 34.057 & $\bar{Y}_{\text {..3. }} \overline{\bar{Y}}_{i, k \text {. form }}$ \\
\hline 47.619 & 40.848 & 33.522 & 40.663 & \\
\hline
\end{tabular}

Then, each of eight sums of squares was calculated as follows:

$$
\begin{aligned}
& \text { due } A: \quad S S_{a}=b c n \sum_{i=1}^{a}\left(\bar{Y}_{i} \ldots-\bar{Y} \ldots\right)^{2}=3 \times 3 \times 49 \\
& {\left[(47.619-40.663)^{2}+\ldots\right]=43,841.574} \\
& \text { due } B: \quad S S_{b}=a c n \sum_{i=1}^{b}(\bar{Y} . j . .-\bar{Y} \ldots)^{2}=140,788.666 \\
& \text { due } C: \quad S S_{C}=a b n \sum_{i=1}^{c}\left(\bar{Y} \ldots k .{ }^{-\bar{Y}} \ldots\right)^{2}=45,221.022 \\
& \text { due } A B: S S_{a b}=c n \sum_{i=1}^{a} \sum_{j=1}^{b}\left(\bar{Y}_{i j \ldots}-\bar{Y}_{i \ldots}{ }^{-\bar{Y}} . j \ldots+\bar{Y} \ldots\right)^{2} \\
& =1461.975
\end{aligned}
$$




$$
\begin{aligned}
& \text { due } A C \text { : } \quad S_{a c}=b n \sum_{i=1}^{a} \sum_{k=1}^{c}\left(\bar{Y}_{i . k .}{ }^{-\bar{Y}_{i}} \ldots{ }^{-\bar{Y}} \ldots k .+{ }^{+\bar{Y}} \ldots\right)^{2} \\
& =1720.488 \\
& \text { due } B C: \quad S S_{b C}=a n \sum_{j=1}^{b} \sum_{k=1}^{c}\left(\bar{Y}_{. j k}{ }^{-\bar{Y}} . j \ldots{ }^{-\bar{Y}} \ldots k .+{ }^{-\bar{Y}} \ldots\right)^{2} \\
& =2578.086 \\
& \text { due } A B C: S S_{a b c}=n \sum_{i=1}^{a} \sum_{j=1}^{b} \sum_{k=1}^{c}\left(\bar{Y}_{i j k .}-\bar{Y}_{i j . .}-\bar{Y}_{i . k} .\right. \\
& \left.{ }^{-\bar{Y}_{. j k .}}{ }^{+\bar{Y}_{i} \ldots{ }+\bar{Y}_{. j} . .+{ }^{+\bar{Y}} \ldots k .}{ }^{-\bar{Y}} \ldots\right)^{2} \\
& =0.369 \\
& \text { Residual SS } r=\sum_{i=1}^{a} \sum_{j=1}^{b} \sum_{k=1}^{c} \sum_{e=1}^{n}\left(Y_{i j k e}-P_{i j k .}\right)^{2} \\
& =382,855.246 \\
& \text { Total } S_{i}=\sum_{i=1}^{a} \sum_{j=1}^{b} \sum_{k=1}^{c} \sum_{e=1}^{n}\left(Y_{i j k e}{ }^{-\gamma} \ldots\right)^{2} \\
& =618,457.802 \\
& S_{e}^{2}=\frac{S S_{r}}{a b c(n-1)}=\frac{382,855.246}{1296}=295.413
\end{aligned}
$$

From these calculations, results in Table IV were obtained. 


\section{APPENDIX K}

\section{ASSIGNMENT OF MA AND SA VALUES TO CAMPGROUUNDS \\ AS SITE ATTRACTIVENESS, $A_{J}$}

The computation, derivation of components and procedural assumptions relative to the $A_{j}$ development are described below.

1. Mix of Activities

A11 the mix activity scale values (MAV) were multiplied by 100.00 as to bring them to the order of magnitude as the site attribute score values (SAV).

A value is given to a park according to the type of activity mixes present at that site; e.g., Bullard Park provides all four activities, it belongs to the "abcd" activity mix and receives a value of 55.64 (Table Iì, page 70 ), while Viento Park has an activity mix of the type "ab" and its value is 2.79 . The mixes of activities provided at a park are indicated by check marks in the column "MA" of Table XV below. The activity mix scale values (MAV) are so indicated in the column "MAV" of the same table.

2. Site Attributes

Let $\mathrm{SAV}_{i j k}$ represent site attribute score value, as predicted by the equation 17 , page 80 . where:

$$
\begin{aligned}
i= & 1,2,3 \text {; type of campsites as attribute } A, \\
j= & 1,2,3 \text {; number of campsites as attribute } B, \\
k= & 1,2,3 \text {; distance away from "other activities" as } \\
& \text { attribute } C,
\end{aligned}
$$


for:

$$
\begin{aligned}
& A 1=\text { primitive campsites for } \$ 2.00 \text { per night, } \\
& \text { A2 }=\text { unimproved campsites for } \$ 3.00 \text { per night, } \\
& \text { A3 }=\text { improved campsites for } \$ 4.00 \text { per night, } \\
& B 1=1-50 \text { campsites, } \\
& B 2=51-100 \text { campsites, } \\
& B 3=101-150 \text { campsites, } \\
& \text { C1 }=2-3 \text { miles, } \\
& C 2=1-2 \text { miles, } \\
& C 3=\text { less than one mile. }
\end{aligned}
$$

Then, the appropriate site attribute score value $\left(S_{i j k}\right)$ can be assigned to the campground using the numbers defined atove for each factor as indices of SAV; e.g., the score value for $i=2(=$ A2), $j=1(=B 1)$ and $k=3(C 3)$ is 45.309. Deschutes Park can be attributed this vaiue since it corresponds to $S A V_{213}$. The $S A V_{i j k}$ for Umpqua Lighthouse is averaged over two scores: $S_{21}$ and $S_{2 A V} 311^{\text {, }}$ that is $(52.370+46.040) / 2=49.180$. However, Viento Park's SAV ijk is not averaged over the two levels of $B\left(S_{213}\right.$ and $\left.S_{22} V_{22}\right)$, but the score value which contributes most of the $A_{j}\left(S A V_{213}\right)$ is used.'

This is due to the fact that the Park and Recreation Branch of the ODOT (Oregon Department of Transportation) recognizes four types of campsites: tent campsites, tent campsites (which are primitive), trailer sites and improved campsites. In this study, the campsites were differentiated into three groups: primitive, unimproved and improved; the following is the campsite "equivalency":

$$
\begin{aligned}
& \text { Primitive campsites (AI) } \begin{array}{l}
\text { Tent campsites which are } \\
\text { primitive }
\end{array}
\end{aligned}
$$

Unimproved campsites (A2) Tent campsites and/or improved campsites (tent campsites with utility hookups)

Improved campsites (A3) Trailer sites

The process of averaging the values will occur only in the cases of $A 7$ and $A 2, A 1$ and $A 3, A 2$ and $A 3$, and vice-versa if these facilities are provided at the same site, and the tent campsites type (by the ODOT definition) is always taken for the $A 2$ since it contributes more to the $A_{j}$ of the site than the tent campsites with utility hookups. 
These values, $S A V_{i j k}$, are placed in the various columns under $S A V_{i j k}$ in Table XV as follows: (1) the SAV $_{i j k}$ is placed in column 1 if the $S A V_{i, j k}$ is based on a single combination of the three attributes; e.g., Deschutes Park, Viento Park, Champoeg Park; ... . (2) the $S A V_{i j k}$ is placed in columns 1 and 2 if the SAV $_{i j k}$ is based on two combinations of the three attributes; e.g., Umpqua Lighthouse Park, Emigrant Springs Park, Lapine Park, . . . .

Column 3 under SAV ijk $_{\text {of the same table shows the final SAV }}$ ojk. $_{\text {. }}$ It is a single number or an average of two numbers depending on which of the two options is applicable to the park under consideration.

The MAV and SAV (column 3) are then added according to the Equation 18, page 81 . The resulting weighted sums are the site attractiveness indices, $A_{j}$. These are shown in Table VII, page 83. They constitute "user preference information". 
TABLE XV

ASSIGNMENT OF MA AND SA VALUES TO THE SPECIFIC

SITE AS SITE ATTRACTIVENESS, $A_{j}$

\begin{tabular}{|c|c|c|c|c|c|c|c|c|c|c|}
\hline \multirow{2}{*}{ I.D. } & \multirow{2}{*}{ Park Name } & \multicolumn{4}{|c|}{$\begin{array}{l}\text { Mix of } \\
\text { Activities - } \\
\text { MA* }\end{array}$} & \multirow{2}{*}{$\begin{array}{c}\text { Site's } \\
\text { Attributes - } \\
\text { SA* }\end{array}$} & \multirow[b]{2}{*}{ MAV** } & \multicolumn{3}{|c|}{$S A V_{i j k}{ }^{* *}$} \\
\hline & & $\bar{a}$ & $\mathrm{~b}$ & c & d & & & 1 & 2 & 3 \\
\hline 1 & Bullards & $\checkmark$ & 1 & $\checkmark$ & $\checkmark$ & $\begin{array}{l}A 2, B 2, C 1, \\
A 3, B 3, C 1\end{array}$ & 55.64 & 47.146 & 28.709 & 37.930 \\
\hline 2 & Champoeg & $\checkmark$ & $\checkmark$ & $\checkmark$ & & $A 2, B 1, C 3$ & 45.78 & 45.309 & -- & 45.309 \\
\hline 3 & Clyde Holliday & $\checkmark$ & & & & $A 2, B 1, C 2$ & -42.74 & 52.310 & -- & 52.310 \\
\hline 4 & Deschutes & $\checkmark$ & & $\checkmark$ & & $A 2, B 1, C 3$ & -2.57 & 45.309 & -- & 45.309 \\
\hline 5 & Emigrant Springs & $\checkmark$ & $\checkmark$ & & & $\begin{array}{l}A 2, B 1, C 3, \\
A 3, B 1, C 3\end{array}$ & 2.79 & 45.309 & 39.039 & 42.170 \\
\hline 6 & Farewell Bend & $\checkmark$ & & $\checkmark$ & $\checkmark$ & $\begin{array}{ll}A 2, & B 2, C 3 \\
A 3, B 1, C 3\end{array}$ & 37.23 & 33.143 & 39.039 & 36.090 \\
\hline 7 & Harris Beach & $\checkmark$ & $\checkmark$ & $\checkmark$ & & $\begin{array}{l}\mathrm{A} 2, \mathrm{~B} 1, \mathrm{C} 3, \\
\mathrm{~A} 3, \mathrm{~B} 1, \mathrm{C} 3\end{array}$ & 45.78 & 45.309 & 39.039 & 42.170 \\
\hline 8 & Lapine & $\checkmark$ & $\checkmark$ & $\checkmark$ & & $\begin{array}{l}\mathrm{A} 2, \mathrm{~B} 1, \mathrm{Cl}, \\
\mathrm{A} 3, \mathrm{~B} 2, \mathrm{Cl}\end{array}$ & 45.78 & 59.312 & 40.875 & 50.390 \\
\hline
\end{tabular}


TABLE XV (Con't.)

\begin{tabular}{|c|c|c|c|c|c|c|c|c|c|c|}
\hline \multirow[b]{2}{*}{ I.D. } & \multirow[b]{2}{*}{ Park Name } & \multicolumn{4}{|c|}{$\begin{array}{l}\text { Mire of } \\
\text { Activities } \\
\text { MAtis }\end{array}$} & \multirow{2}{*}{$\begin{array}{c}\text { Site's } \\
\text { Attributes - } \\
\text { SBi* }\end{array}$} & \multirow[b]{2}{*}{ MAV $* *:$} & \multicolumn{3}{|c|}{$S A V_{i j k}{ }^{* * *}$} \\
\hline & & a) & $\mathrm{B}$ & 6 & $d$ & & & 1 & 2 & 3 \\
\hline 9 & Milo McIver & $y$ & $\checkmark$ & $r$ & & $A 2, B T, C 3$ & 45,78 & 45.309 & -. & 45.309 \\
\hline 10 & Silver Falls & $\checkmark$ & $\checkmark$ & $\checkmark$ & & $\mathrm{A} 2, \mathrm{BT}, \mathrm{C} 2$ & 45.78 & 52.310 & - & 52.310 \\
\hline 11 & Sunset Bay & $\checkmark$ & $\checkmark$ & $\checkmark$ & & $A 2, B 1, C 3$ & 45.78 & 45.309 & - & 45.309 \\
\hline 12 & William Tugman & $\checkmark$ & & $\checkmark$ & & $A 2, B 3, C 3$ & -2.57 & 20.976 & -- & 20.976 \\
\hline 13 & Tuma 10 & $\checkmark$ & $\checkmark$ & $v$ & & $\begin{array}{l}A 2, B 2, C 1, \\
A 3, B 1, C 1\end{array}$ & 45.78 & 47.146 & 53.042 & 50.090 \\
\hline 14 & Umpqua Lighthouse & $\checkmark$ & $\checkmark$ & & & $\begin{array}{l}A 2, B 1, C 2, \\
A 3, B 1, C 2\end{array}$ & 2.79 & 52.310 & 46.040 & 49.175 \\
\hline 15 & Unity Lake & $\checkmark$ & & $\checkmark$ & & $A 2, B 1, C 3$ & -2.57 & 45.309 & -- & 45.309 \\
\hline 16 & Viento & $v$ & $\checkmark$ & & & $A 2, E 1, C 3$ & 2.79 & 45.309 & -- & 45.309 \\
\hline
\end{tabular}

*Compiled from Oregon Park maps and Oregon State Parks descriptions obtained from Parks and Recreation Branch of ODOT.

**As obtained from Tables III (MAV).

***As derived from equation 17. Table VI also shows these values, under the column marked "Predicted". Indicates that the mix of activities check marked is provided at that site. 